\title{
اتجاهات معلمي التعليم العام نحو تطبيق التقويم الشامل وتأثرها ببعض التيفيرات العام الديموجرافيتية
}

\author{
د. صبحي بن سعيد عويض الحارثي \\ استاذ التربيتشالخاصتّ وعلم النفس المثارك \\ كليت التربيتة-جامعتام القرى
}





\section{الإلخ صـ:}

هدفت هذه الدراسة إلى التعرف على (اتجاهات معلمــي التعلــيم العــام

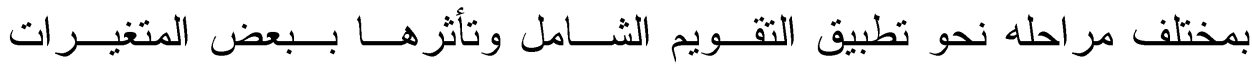
الديموجر افية) قد اعتمد على المنهج الوصفي "المسحي"،وضم مجتمع الدر اســـة معلمي مدارس التعليم العام التي تم تقويمها.وقد تكونت عينة الدر اسة من(99 (19)

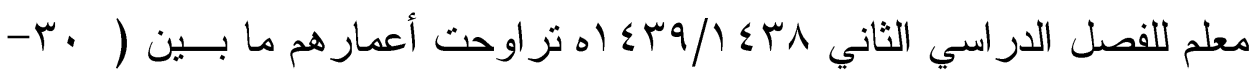

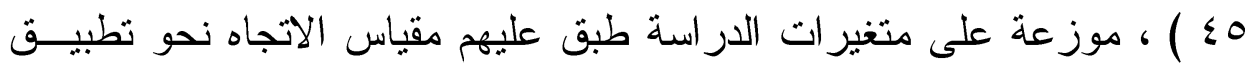
التقويم الثامل • وكان من أهم النتائج التي توصلت إليها الدر اسة. وجود اتجاهات إيجابية لاى أفر اد العينة نحو التقويم الشامل ، و اتفاق عام بين أفر اد العينة حول العو امل المؤدية لنجاح تطبيق التقويم الثامل للمدرسة . و عدم وجود فروق دالة إحصائيًا في الاتجاهات بين أفر اد العينة ترجع إلى المؤهل الدراسي أو الخبرة . الكلمات المثتاحيةة: اتجاهات المعلمين - التقويم الثامل - المؤهل الاراســي - ســنوات الخبرة- المرحلة التعليمية التي يعملون فيها. 
The aim of this study was to identify (Trends of general education teachers in various stages towards the application of the comprehensive assessment and its impact on demographic variables)

\section{Abstract:}

Has been based on the descriptive method "survey", and included the school community teachers of public education schools that have been evaluated. The study sample consisted of (199) teachers for the second semester 1438/1439 AH, Their ages ranged from (30-45). Distributed on the study variables applied a measure of the trend towards the application of the comprehensive calendar. One of the most important findings of the study, Positive attitudes of the sample towards a comprehensive evaluation, And a general agreement among the respondents on the factors leading to the successful implementation of the comprehensive school calendar. And the absence of statistically significant differences in the trends between the sample members due to the academic qualification or experience.

\section{Key terminologies:}

Teacher Attitudes -Comprehensive Calendar-Educational Qualification- Years of Experience - The educational stage in which they work. 


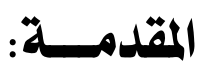

يعد تقويم المدرسة الثامل أحد الأساليب المهمة و الناجحة التـي تحقـق

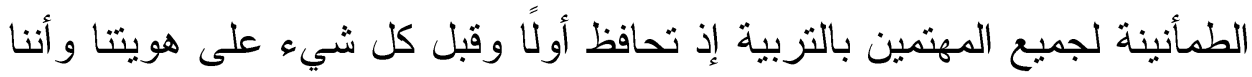

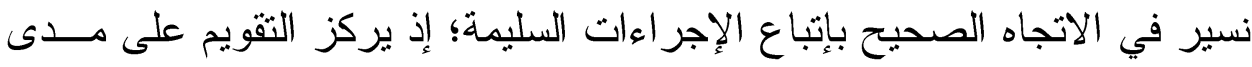
قدرة القيادة و الإدارة على إيجاد مدرسة فاعلة، و الحفاظ على المستويات التعليمية المختلفة وجودة التعليم المقدم. فالاتجاهات التربوية المعاصرة تدعو إلى ضرورة إيجاد نظام تعليمي يحقق الجودة الثاملة. و التميز في العملية التعليمية لذلك كسان

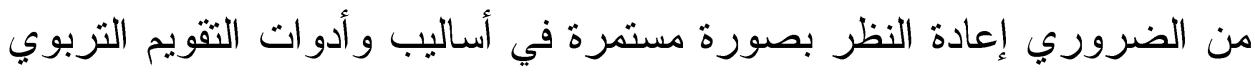
وتطوير ها، بحيث تحقق شروط الثقويم الجيد الذي يتسم بالاستمر ارية و الثــمول

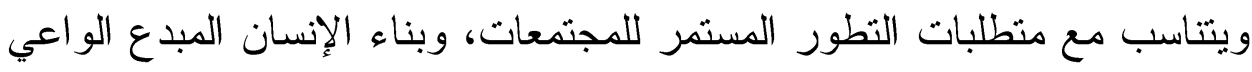
الدركك لمشكلات مجتمعه وحاجاته ومتطلبات نموه وتقدمه، و هذا يستلزم تعاون

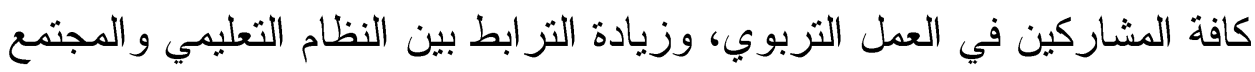

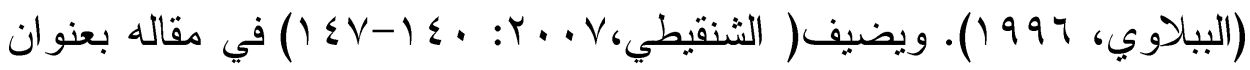

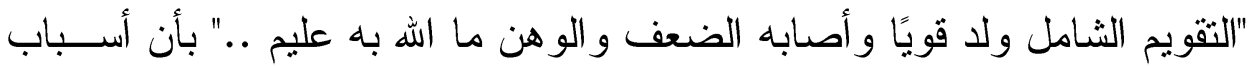
الضعف تعود إلى العديد من العوامل الداخلية في آلية عمـلـل التقــويم الثـــامل وعو امل خارجية تتعلق بالمعارضة له في الميدان حيــث تســى المؤسســات التعليمية جاهدة إلى تحقيق أفضل إعداد للطلاب، ويتأنى ذلك من خلال تحقبــق

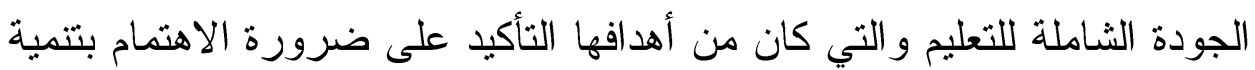
جميع جو انب شخصية الطالب ومنابعة تقدمه وتحويله من متعلم سلبي إلى متعلم نشط، و إثر الك كل من له صلة بالطلاب في تحقيق هذا الهدف، وتطوير البرامج

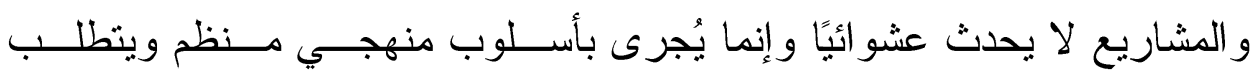

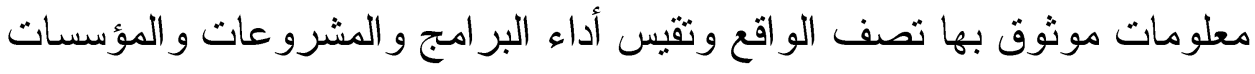

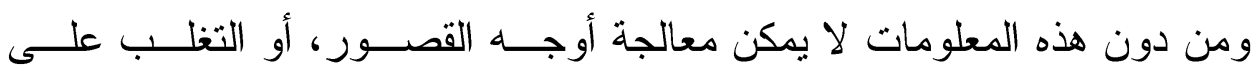

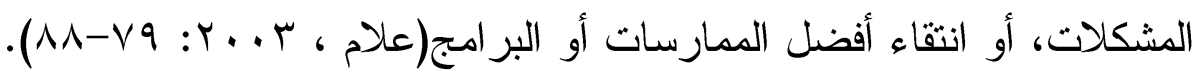


ولما كان مشروع التقويم الشامل أحد البرامج التربوية المهمة في وزارة التربية و التعليم بالمملكة العربية السعودية فمن الضروري إخضـــاعه لعمليــة التقــويم لضمان التأكد من سيره في الاتجاه الذي يحقق أهدافه وتطوير آلياته و إجراءاته،

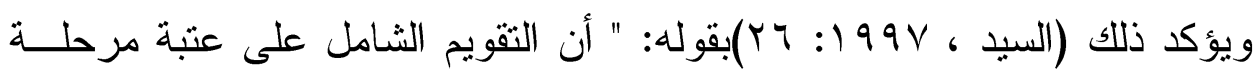
جديدة تتطلب وقفة تقويمية تستلهم من الماضي الدروس و العبر، وتستشرف مـنـ الحاضر معالم المستقبل".

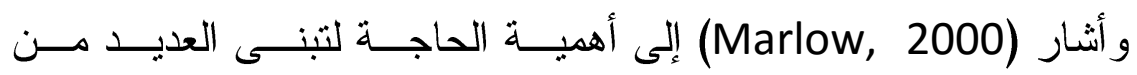
الإجراءات التي تستخدم لتقدير تقدم الطالب و إنجازه، و التي منها طرق التقــويم الكمي القائمة على فكرة الثقويم الثامل، و الذي يتابع كيفية اكتساب وتطور ونمو المهارات، وكيفية تكوين الاتجاهات، وتشكيل البناء المعرفي للطلاب من خــلال الاحتفاظ بمذكرات تفصيلية عن إنجاز الطلاب، ووجود سجل لكل طالب، و إعداد تقارير دورية عن مدى تقدمه و أدائه. وفكرة شمول عملية التقويم ليســـ فكـرة جديدة، بل هي فكرة نادى بها جميع المهتمين بالعملية التعليمية منذ القدم، ولكن لم تكن هناك آليات لكيفية تنفيذ تلاك الفكرة، لذلك فقد كانت فكرة نظرية أكثر منهــا و اقعًا عمليًا، لذلك كان من الضروري البحث عن طريقة لتفعيل هذا الثرط المهم من شروط نجاح عملية التقويم (Winefield, 1991).

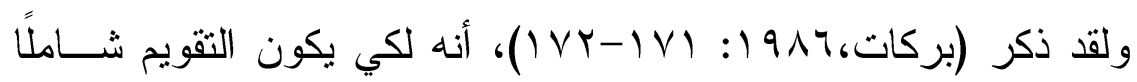
يجب أن يكون محققًا لأهدافه، ويجب ألا يقتصر على قياس كمية المعلومات لدى التلميذ و إنما ينبغني أن يقيس مدى استفادة الطالب مما تعلم في مو اقـــ حقيقةـــة توظف فيها هذه المعلومات. فمن المعلوم لنا جميعًا أن كل ما لا يخضع للتئـويم

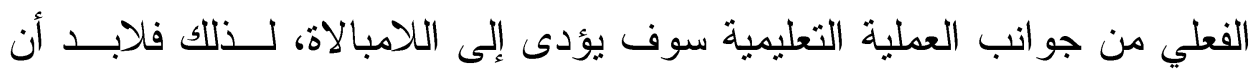

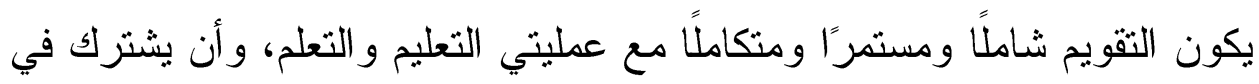


الحكم على الطالب أكثر من معلم، و أن يكون التقويم متحديًا لقــدرات الطالــب حافزًا له لبذل أقصى طاقته وجهده (مرسى، 1990 (: 100 (1).

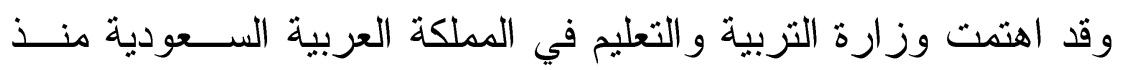
أكثر من عشر سنوات ثقريبًا بالتقويم الشامل حيث تم التجريب في مدرستين، ثم في منطقتين من مناطق المملكة العربة السعودية ،وذلك من أجل دراســة و اقــع المدارس وتشخيص الإيجابيات وتطويرها و الحد من الصعوبات التـي يعانيهــا مديرو المدارس ومعالجتها، وذلك من أجل الرقي بمستوى التربية و التعليم و التأكد من قبام المدرسة بالمهام و المسؤوليات الموكلة إليها. (الدوسري، ج ج . ب). فالثقويم الثامل ليس مجرد عملية قياس فقط و إنما هو سلسلة متر ابطـــة

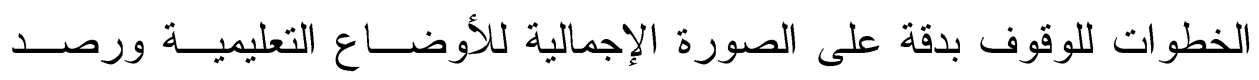
المتغيرات التي تؤثر في الكفاءة الداخلية والخارجية للمــدارس وفاعليــة الأداء لنظام التعليم و النظم المرتبطة بها، ويعتمد التقويم الشامل للمدرسة علــى أدوات ملاحظة مقننه و استبيانات لجمع البيانات من مختلف عناصر المدرسة المقسـمة

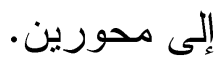
الأول: محور المادة الدر اسية وفيه يتم تقويم المـــواد الأساســية (الــدين، اللغـــة العربية، الرياضيات، العلوم، اللغة الانجليزية). الثاني : المحور العام ويشمل تقويم تسعة عناصر (مستوى حضـــور الطــلاب، النمو الخلقي والاجتماعي، التوجيه و الإرشاد، النشــاط الطلابــي، الإدارة المدرسية، البر امج و الأنشطة الإضافية، علاقة المدرسة بأوليــاء الأمــور و المجتمع المحلي، المباني المدرسية) .ويتم تقويم المدرسة بناءً على خطة

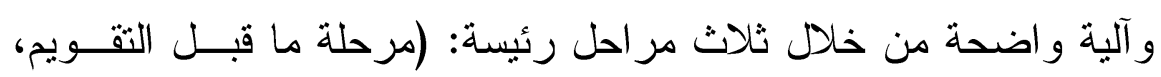
ومرحلة التقويم، ومرحلة ما بعد التقويم)، ويقوم بعملية التقويم مشــرفون متفرغون للقيام بهذا العمل، وفي ختام عملية التقويم يعتمد تقرير إلكتروني 
مفصل بالإيجابيات و السلبيات لكافة عملية التقويم بقدم لمــدير المدرســة ويبني في ضوء خطة علاجية لمعالجة السلبيات وتعزيـز الإيجابيــات . (الدليل العام لتقويم المدرسة الثامل، ه . . r). وتثقوم فكرة التقويم الثامل للمدرسة على تقويم كافة عناصر المدرسة من قبــل فريــق تقويم مستقل

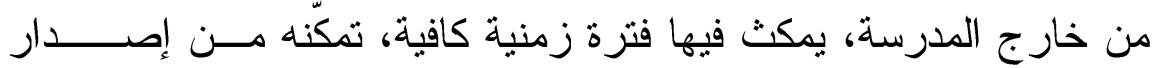

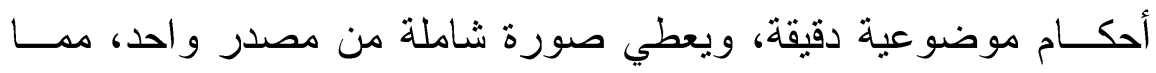
يتيح لصاحب القرار الاستفادة منها عند وضع الخطط التطويرية (أخضر ، $(r \cdot \lambda$

ولقد تبنت وزارة التربية و التعليم فكرة تطبيق التقويم الثامل فـي العــام

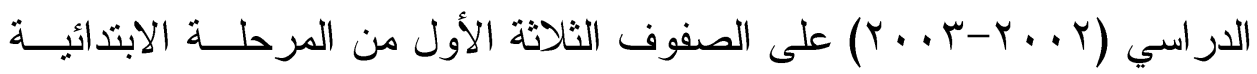
وبدأت في صيف ذلك العام في تدريب بعض المعلمين و المشرفين علــى كيفيــة

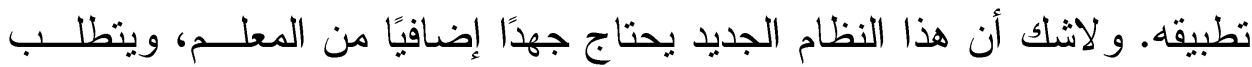
معلمًا مؤمناً برسالته ر اضيًا عن عمله، لذلك فإن اتجاهات المعلمين نحو تطبيــق التقويم الثامل ،ايمانهر به وبجدو اه، وتدريبهم على كيفية تطبيق كل ذلــك يعـد أساسًا لنجاح منظومة التقويم الشامل، فإذا كانت الاتجاهات إيجابية سيدفع ذلـــك المعلم إلى بذل المزيد من الجهد لتعظيم درجة الاستفادة منه.(الثـــايع، عبــــالله

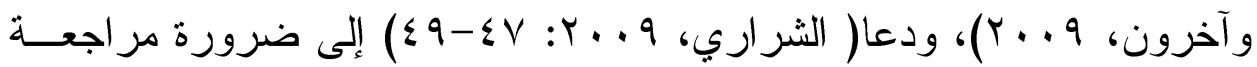

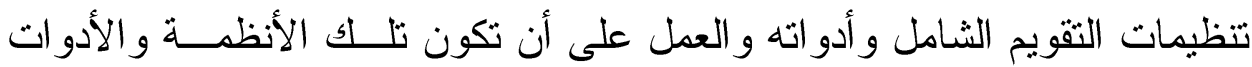
متو افقة مع النظام التعليمي ككل. ويبقى مشروع التقويم الثامل متأرجحًــا بــين مؤيد لاستمر اره ومعارض لبقائه، بناءً على عدة معايير، و الاتجاه نحو ما يقوم

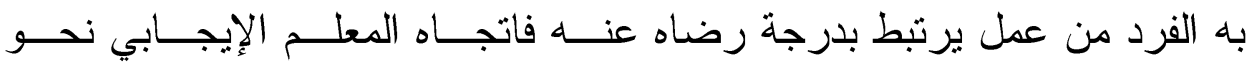
الممارسات التربوية يؤثر بلا شك على رضاه عن عمله ويرفـع مــن مســتوى صحته النفسية. 
إن لكل إنسان موقفا ور أياً حول العمل الذي يقوم به، وهذا الموقف الـذي

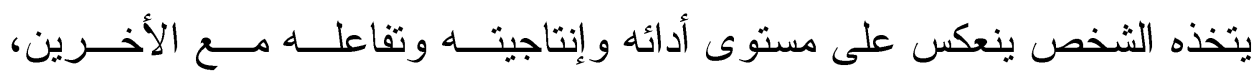
وبالتالي إما أن يساعد في تحسين مستوى المؤسسة التي يعمل بها، أو يؤدي الى تز اجع هذا المستوى، ولهذا السبب وبشكل أساسي فإن عمليــة العنايــة باتجــــاه

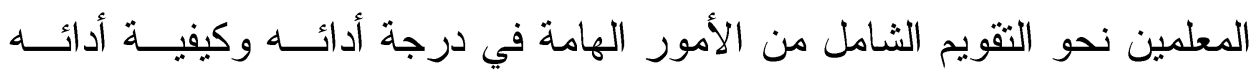
وتعامله مع طلابه وزملائه. و وتلعب اتجاهات المعلمين نحو التقويم الثامل دوراً هاماً يؤثر في قدرته على تحقيق الأهداف التعليمية المنشودة. و لأن التعلم الذي يؤدي لتكوين اتجاهات نفسية مناسبة لاى المتعلمين يكون أكثر جدوى من التعلم القائم على اكتساب المعرفة فقط. و المعلم يحمل معه اتجاهاته وميوله وخبر اته مع طلابه، ولهذه الاتجاهات الــدور الكبيــر فــي العمليــة التعليميــة (الثـــرعة

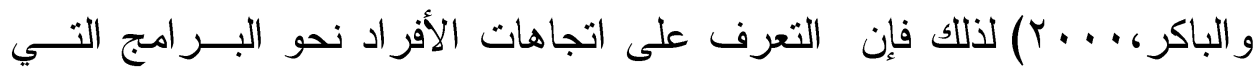
يساهمون فيها و التغيرات التي يمكن أن تساهم في تعديل تلك البرامج، أمر بــالغ الأهمية بالنسبة للمسؤولين و القائمين علي تخطيطها وتنفيذها، لذلك فقد استهدفت

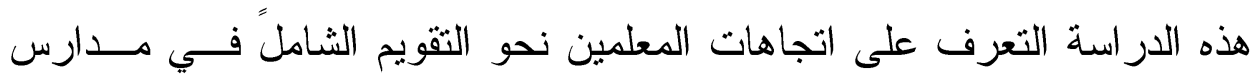
التعليم العام، و التعرف على ما إذا كانت هنالك فروق ذات دلالة إحصائية تعزى لمتغير ات المؤهل العلمي، و المرحلة التعليمية، و عدد سنوات الخبرة.وقد لاحـــ الباحث من خلال عمله في مجال تدريب عينــة مــن المعلمـين خــلال العــام

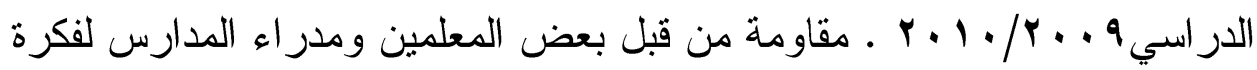
نظام التقويم الشامل، و اعتر اضًا كبيرًا على تطبيقه، مما دعا لإجراء هذه الدراسة للكشف عن اتجاهات المعلمين نحو تطبيق التقويم الشامل وتحديد مدى تـأثر هذه الاتجاهات بمتغيرات المؤهل الاراسي للمعلمين وسنوات خبرتهم والمرحلة التعليمية التي يعملون فيها. 


\section{مشكلة الدراسة:}

بظهور مفهوم التقويم الشامل كانت هناك حاجة متز ايدة لتدريب المعلمين

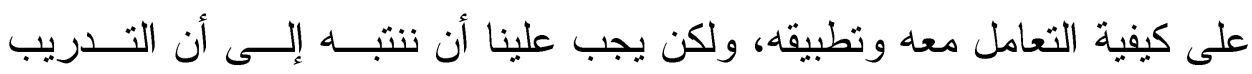
سوف يؤتى ثماره إذا ما تم تعديل اتجاهات المعلمين وتعديل معارفهم ومهار اتهم في استخدامه، والتأكيد على أن هذا النظام الجديد يكتسب تأيبدًا وشعبية كبيــرة، Marilyn, ) فو ائده على العملية التعليمية أكبر بكثير مما نتوقع مــن سـلبياته 66 (2005) ولقد ز اد الاهتمام في مجال تقويم نو اتج التعلم بما يســمى بملــف الإنجاز (البورتفوليو) حتى أصبح التقويم من خلاله من الاتجاهات السائدة فـي

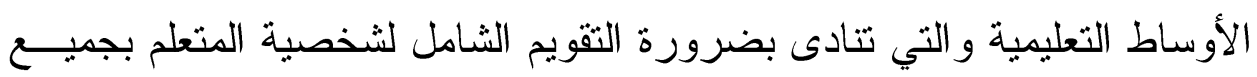
جو انبها المعرفية منها وغير المعرفية بحيث يصبح كل أداء يقوم به التلميذ داخل الفصل أو خارجه مجالًا للتقويم (Wiggins, 1990: 299-307). ولقد ظهر مشروع الثقويم الثامل نتيجة الحاجة إلى اســتحداث طريقــة جديدة للتقبيم و المتابعة تعتمد على وثائق رسمية تستثمر طاقات الطلاب وتجعـل عملية التعلم عملية نشطة، ويأتي ذلك استكمالًا لمشروعات تطوير التعليم، و التي لا يمكن التغاضي فيها عن دور عملية التقويم في تحسين الأداء.(عرفان، ه . . ب؛

(Yehudit\&orit, 2005: 1413-1446 ولقد ذكر كريستوفر (418-382 : Christopher, 2004) أنـــه ينبغــي تدريب المعلمين على استخدام(البورتفوليو) قبل تطبيقه حتى نتجنب النتائج السلبية الناتجة عن تطبيقه بدون وعي، بل يجب أن يكون التدريب عليه جزء من إعداد المعلم.

ويرى الباحث أن إصلاح النظام التعليمي يجب أن يبدأ من عملية التقويم، و الذي يقصد به نظام الحكم على جودة المنتج التعليمي، الأمر الذي معه يمكـنـن القول إن التقويم يقود العملية التعليمية بجميع مكوناتها الى الإصلاح التربــوي، وتحسينه يقضى على كثير من مشكلاتها. 
ولقد نبعت مشكلة الدراسة من إحساس الباحث أين تأكيد ذلكك من خــلال

نتائج الدراسات السابقة بوجود تباين في اتجاهات المعلمين ومــدر اء المــدارس نحو تطبيق التقويم الشامل، حيث أقيمت عدة دورات تدريبية في مركز التـدريب التربوي للقيادات التربوية و المعلمين بمختلف مكاتب الإشر اف بمحافظة الطائف،

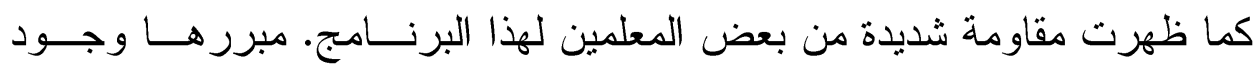

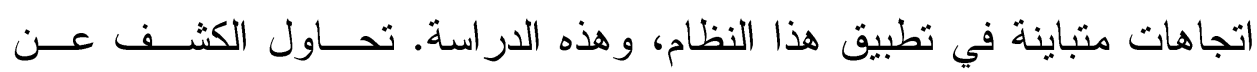
اتجاهات المعلمين نحو تطبيق التقويم الثامل، ومدى تأثر هذه الاتجاهات ببعض هـ المتغير ات كما بدركها معلمي التعليم العام.

وتثير مشكلة الار اسة التساؤلات التالبة:

ا - ما هي اتجاهات المعلمين نحو تطبيق التقويم الشامل؟ r- هل توجد فروق ذات دلالة إحصائية ببن المعلمين في اتجاهاتهم نحو تطبـق التقويم الثامل في المدارس تعزى للمتغير ات الآتية: أ- المؤهل العلمي.

$$
\text { ب- سنوات الخبرة. }
$$

ج- المرحلة التعليمية التي يعملون بها (ابتائي -متوسط-ثانوي)؟

\section{هلدفة اللدراسة: \\ تهذف هذه الار اسة إلى:}

ا - التعرف على اتجاهات المعلمين نحو تطبيق التقويم الثامل.

r- بيان الفروق في اتجاهات المعلمين نحو تطبيق التقــويم الثـــامل وفقًــا لسنوات الخبرة، و المؤهل التعليمي، ونوع المدرسة (المرحلة التعليميــة

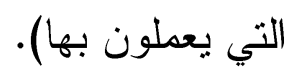




\section{مبررات الدراسة:}

1- تثتاول الدر اسة اتجاهاً تربوياً معاصر اً وهو التقويم الثامل للمدرسة الـذـي

يهــدف إلي معرفة جوانب القوة والضعف في العمل المدرسي.

ץ- وجود عدة ملاحظات على نظام التقويم الشامل الحالي من قبــلـل القــائمين

$$
\text { علــى تطبيةـــهـ و العاملين في الميدان }
$$

ب- أهمية التقويم ،وبالذات إذا كان شاملا لجميع عناصر المدرسة في تطــــير و إصلاح التعليم.

\section{أهمية الدراسة:}

تتضح أهمية هذه الدر اسة في الجو انب التي تتصدى لدر استها:

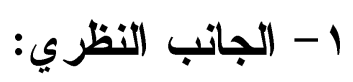

- توفير المعلومات و البيانات و الدر اسات النظرية الخاصة بالتقويم الشامل. - تتاولها لموضوع التقويم الثامل و الذي يعد من أهم أركان العمليــة التعليميـــة و الذي يوجه كل المكونات الأخرى، ونتائجه تؤثز في كل من له صلة بــأمر

$$
\text { التعليم. }
$$

- تركيز الدراسة على المعلم و أنه محور العملية التعليمية باتجاهاته ورضاه عن عمله.

- نجاح مشروع المعايير الوطنية للتعليم يعتمد بدرجة كبيرة على نجاح عمليــة التقويم، فبات من الضروري التعرف على العو امل التي تؤثر فيه.

- الإصلاح و النطوير المبنى على تشخيص الواقع وتقييمه باستمر ار لأهم سمات العصر الحاضر. 


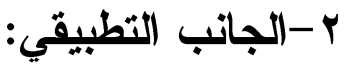

- قد تفيد هذه الدراسة المتخصصين و المسئولين في المجال التعليمي في التعرف على الاتجاهات (الإيجابية-السلبية) تجاه الثقويم الثامل.

- ضرورة الحاجة إلى تقديم تغذية راجعة إلى متخذي القرار عن نتيجة تطبيـق نظام جديد وذلك لتدبير الإجراءات الكفيلة بتحسين الاتجاهات وتذليل العقبـات البـات

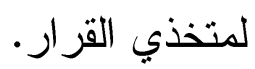

- ضرورة تقديم التخذية الر اجعة باستطلاع آراء المعلمين فيما هم بصدد تطبيقه، وتدريبهم التدريب الكافي عليه.

\section{المفاهيم الإجرائية للدراسة:}

\section{1 الاتجاهات:Attitudes}

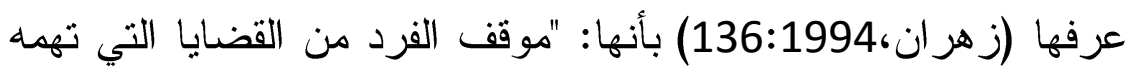

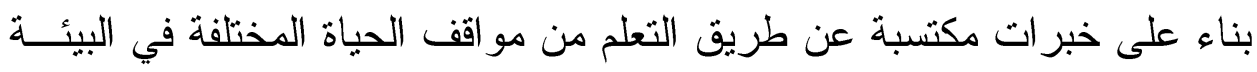

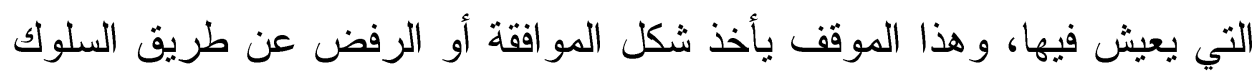
اللفظي أو العملي للفرد".

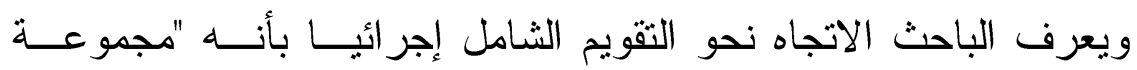

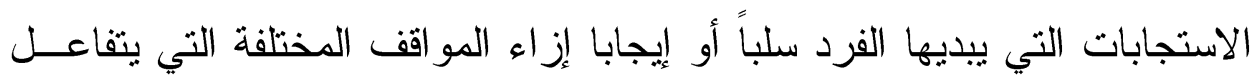

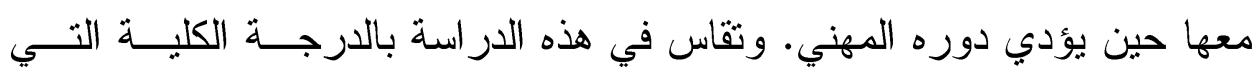
يحصل عليها الفرد في مقياس الاتجاهات نحو التقويم الثامل". التعريف الإجرائي يجب أن يتضمن أبعاد المقياس واسم المقياس ومن هو المعد

\section{ب - التقويم الشامل Comprehensive evaluation}

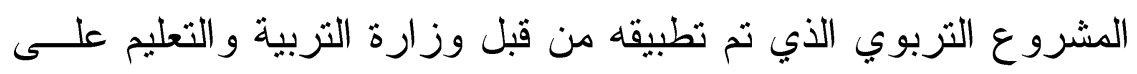

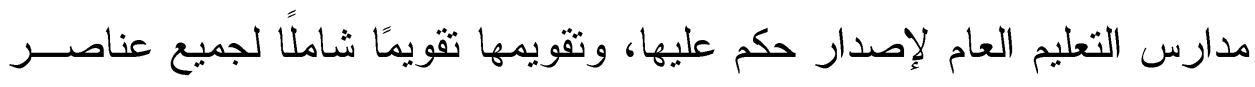

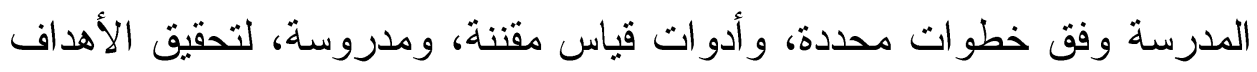


التربوية المرجوة. (الدليل العام لتقويم المدرسة الشامل، ه . . ب). ويعرف الباحث "التقويم الشامل "بأنه إصدار حكم على المدرسة يتعلق بجودتها ومدى فاعليتهــا كمؤسسة تربوية لها أهدافها تسعى إلى تحقبقها". ب- اتجاهات المعلمين نحو تطبيق التقويم الشامل: Teachers' attitudes towards the application of the comprehensive evaluation.

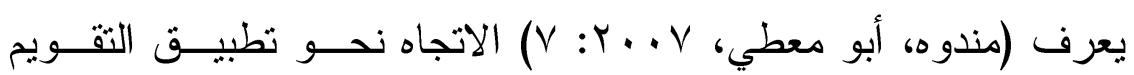
الثامل بأنه (وعي المعلمين بجدوى التقويم الثامل، وردود أفعالهم تجاهه ســـواء

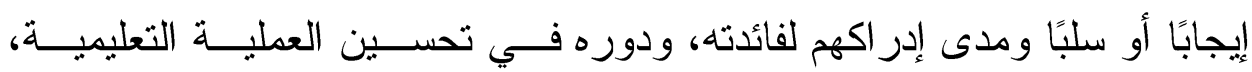
و الارتقاء بمستوى الطلاب، وفهمه لمدى اختلافه عن طرق التقـــيم التقليديــة) ويعرف إجرائيًا بأنها الدرجة التي يحصل عليها المعلــم علــى مقيــاس اتجــاه المعلمين نحو تطبيق التقويم الثامل المستخدم في الدراسة.

\section{محلددات اللدراسةة:}

تتمثل محددات الدراسة في العينة وهم معلمو التعليم العــام (ابتــدائي-

متوسط-ثانوي) بمحافظة الطائف في المملكة العربية السعودية للعـام الدراسـي

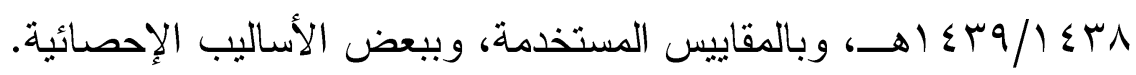

اللدراسات السابقة:

يوجد عدد من الدراسات السابقة التــي بحثــ فــي التقــويم الثـــامل، يستعرض الباحث أكثر ها ارتباطًا بهذه الدراسة .

أجرى (شُلبى، 1998) دراسة هدفت التعرف على اتجاهات المعلمــين نحو إلغاء التقويم البنائي بمر احل التعليم العام، وقد تكونت عينة الدراســـة مــن فئتين الأولى ( r r ) طالبًا وطالبة بالفرقة الثانية من المرحلة الإعدادية، و الثانية

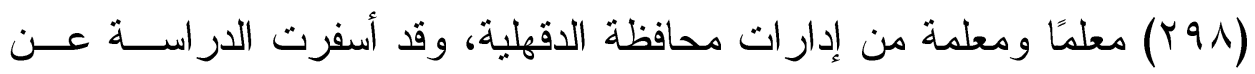




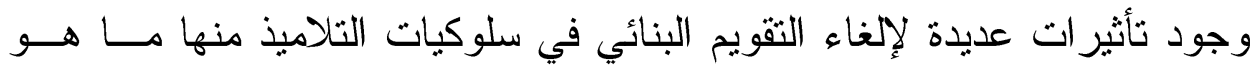
أكاديمي كانخفاض التحصيل، ومنها ما هو سلوكي كتمرد الطلاب على النظــام داخل الفصل، ومنها ما هو مهني كانخفاض فاعلية المنزل و المدرســة فـي أداء الدور المنوط بهما، كما أن معلمي مراحل التعليم العام غير موافقين على إلغـــاء التقويم البنائي لما له من ميزات و آثار حسنة على سير العملية التعليمية.

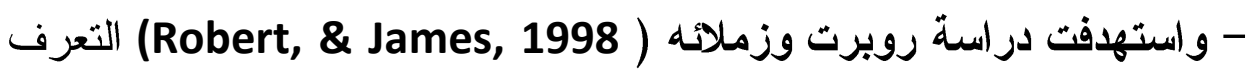
على جدوى التقويم الشامل ودور الحقيبة التعليمية في تحسين أداء الطــلاب، وقد أجريت الدر اسة على طلاب بعض كليات الجامعة و عددهم . ro طالب)

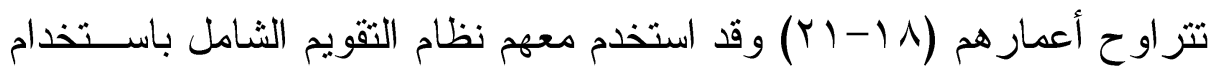
الحقائب التعليمية، وقد أسفرت الدراسة عن وجود تأثير فعال للتقويم الثـــامل في تحسين أداء الطلاب بالجامعة مقارنة بأقر انهم في الكليات الأخرى التي لم تستخدم نظام التقويم الثامل و الحقائب التعليمية. - وقام (George, 2001) بدراسة استهدفت التعرف على آثار تطبيق التقـــيم الشامل على التحصبل، وكذا التعرف على أنواع الدعم الذي يقــدم للمعلمــين لمساعدتهم على تطبيق التقويم الثامل، وذلك في المنــاطق التــي وضــعت معايير ها متضمنة تطوير أداء المعلمين من خلال استخدام الحقائب التعليميـة الإلكترونية، وقد أجريت الدراسة على (YV0) معلمًا يعملون بمدارس ريفيـة،

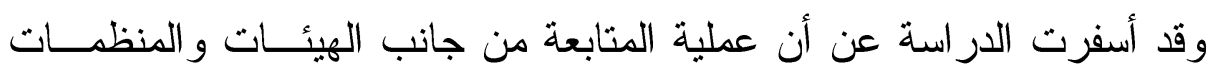
المنوط بها أمر التعليم كانت مهمة جدًا لحسن سير تطبيق منظومــة التقــويم الثامل، كما عبر المعلمون عن وجهة نظر هم في التقويم الثامل بأنه ساعد في تحسين تحصيل الطلاب. 
و هـدفت دراســة ) Ailanowski,, Herbert \&

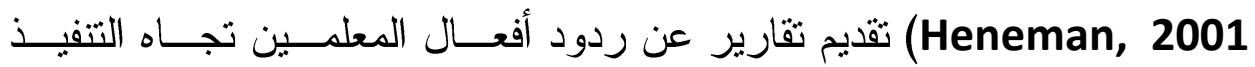

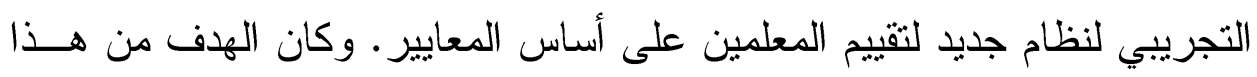

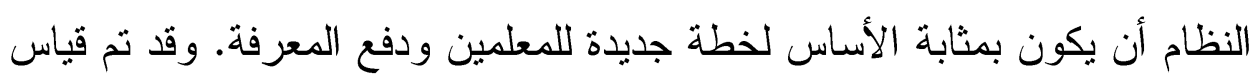

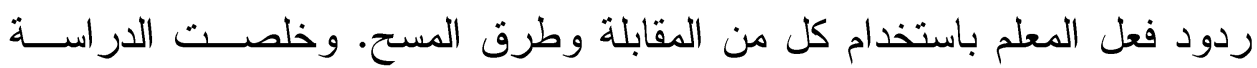

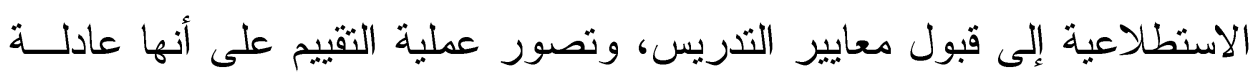

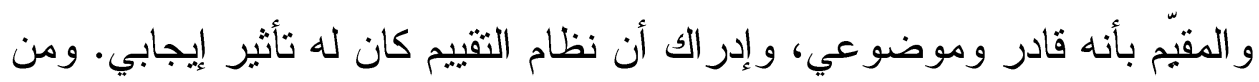

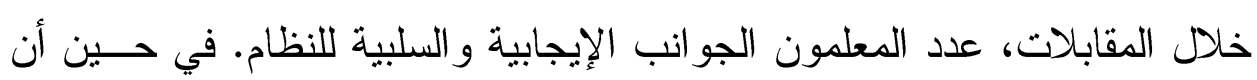

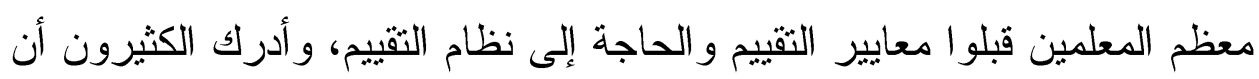
النظام أضاف الكثير إلى أعباء عمل المعلمين. وبناءً على هذه النتائج، تم إجراء العديد من التغييرات في نظام التقييم الثامل قبل التتفيذ الكامل.

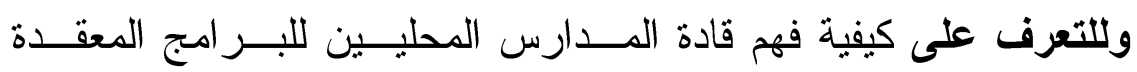

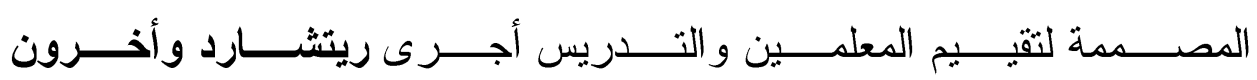
(Richard Halverson, Carolyn Kelley, Steven Kimball, 2004) دراسة حيث تعتمد سياسات تقييم المعلمين الجديدة المستندة إلى المعايير على بـى

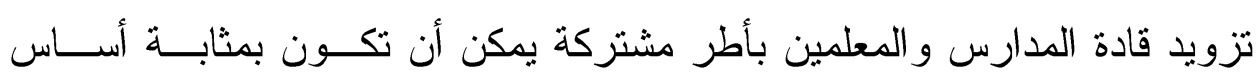

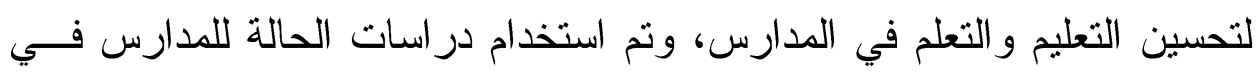
منطقة ددرسية كبيرة لفحص التتفيذ على مستوى الددرسة لنظام تقييم المعلم القائم

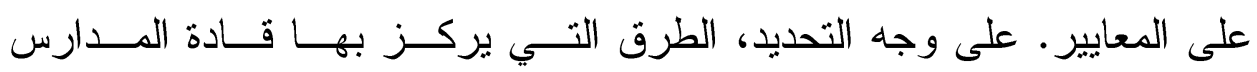

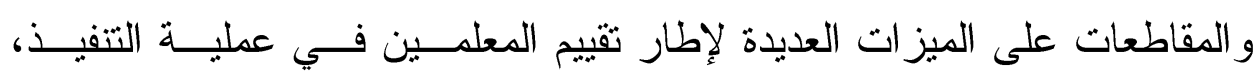

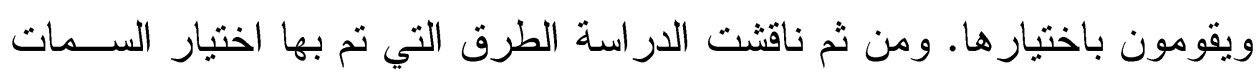

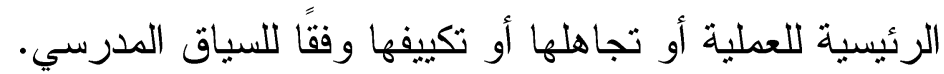


أما دراسة كر يستوفر (Christopher, 2004 فاستهدفت التعرف على

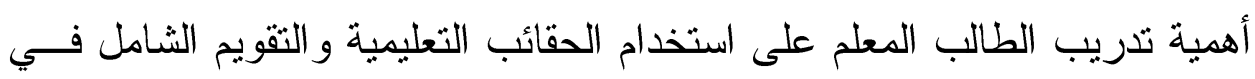

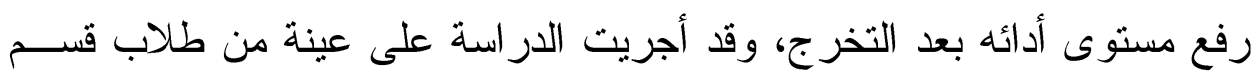

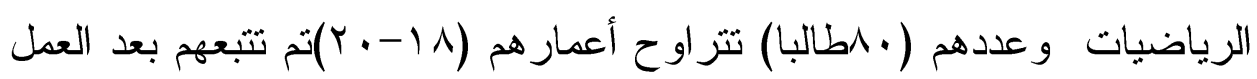

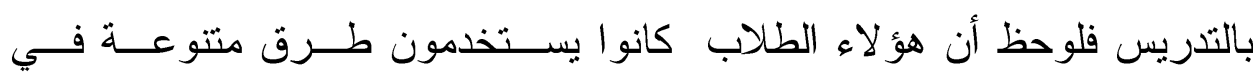

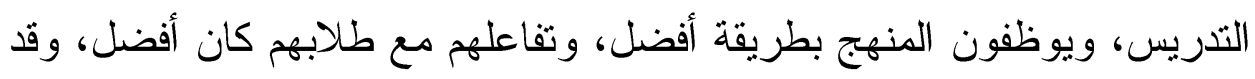

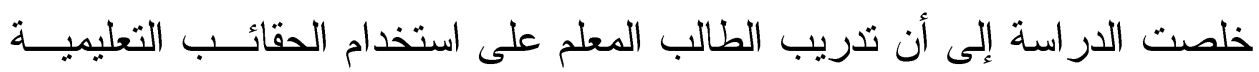
يحسن من أدائه وتفاعله الإيجابي مع طلابه فيما بعد.

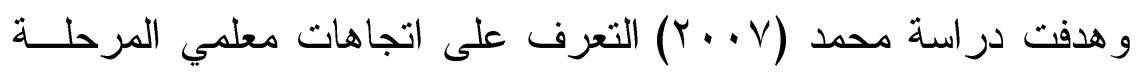

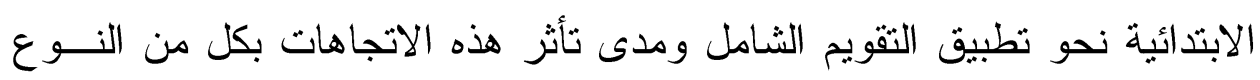

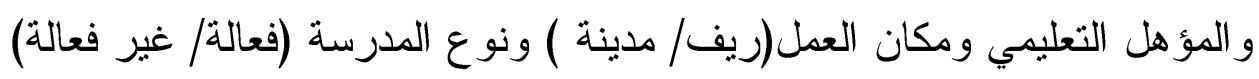

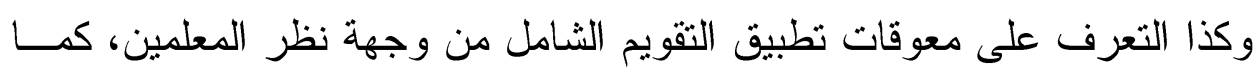

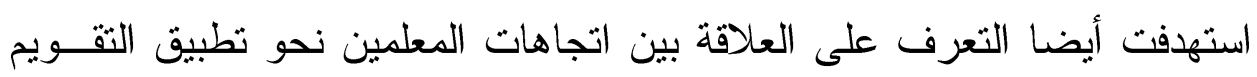

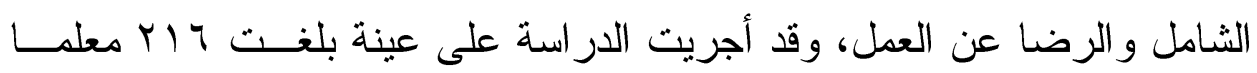

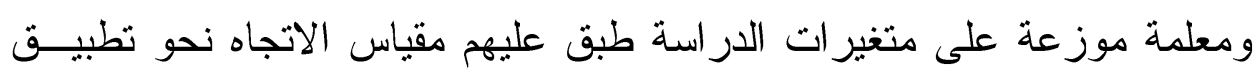

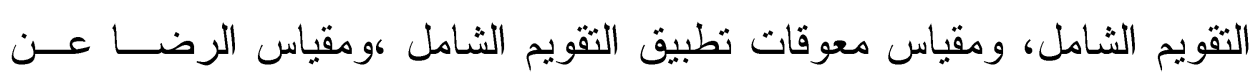

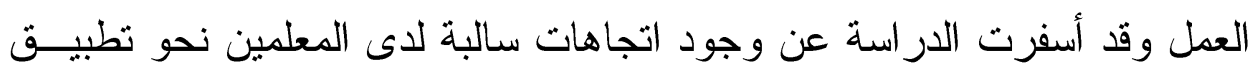

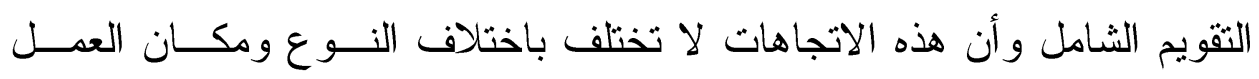
(ريف/مدينة) أو المؤهل التعليمي (منوسط - عالي) أو التفاعل التهات بين مكان العمل

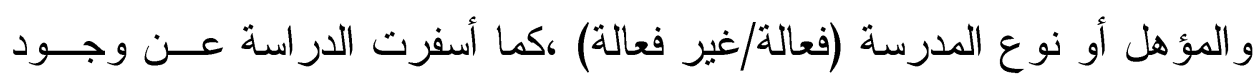

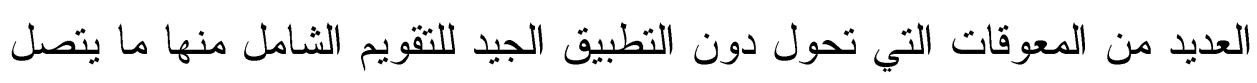

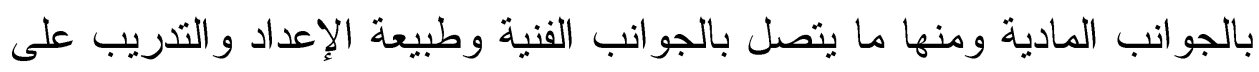

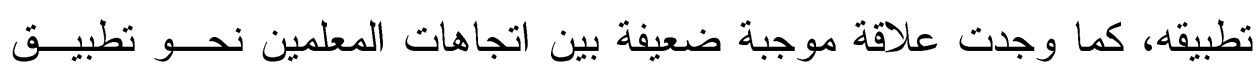


التقويم الثامل ودرجة رضاهم عن عملهم الذي وصف بأنه منخفض، وقد قـدم الباحثان عددا من التوصيات والتطبيقات التزبوية والبحوث المقترحة و التي تزيد من فعالية التقويم الثامل ورضا المعلمين عن عملهر.

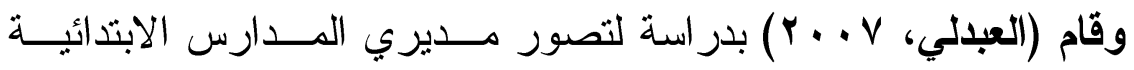
لتطبيق خطة الثقويم الثامل في محافظة القنفذة في المملكة العربيــة الســعودية وتوصل الباحث إلى مجموعة من النتائج أهمها تأكيد مديري المدارس على الدقة و المتابعة في تتفيذ خطة التقويم الثامل من جانب حضور المعلمـين و الالتــز ام بالعمل، إثارة التتافس بين الطلبة، تفهم المشكلات و اكتشاف الطلبة الموهــوبين،

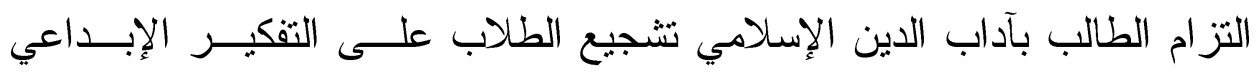
و المهاري وتتمية الاتجاهات الإيجابية، تشجيع الطلبة علـى البحـــ و التقصـي وتتمية الاتجاه الفكري والإبداعي الابتكاري، تأكيد تدريب المعلمين علـى إدارة الصف و انضباطه وتوصيل المادة العلمية بالطر ائق و الأساليب الحديثــة وتأكيــد

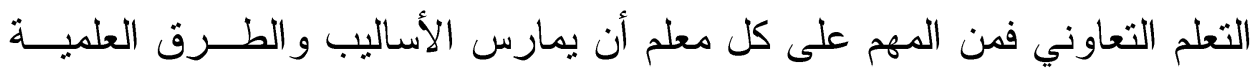
الحديثة ويطبقها مع استخدام التقنيات التعليمية الحديثة التي تساعد على توضــيح المادة العلمية وتوصيلها للطلاب وتأكيد القدرة على اتخاذ القرار المناسب، وأهم الصعوبات و العقبات التي تواجه تتفيذ خطة الثقويم الشامل تكمن بشكل أساسي في وني مجال الطلاب و المعلمين إذ حصلت على أعلى وزن مئوي نسبى وهذا يدل على أن مديري المدارس الابتدائية لم يشاركوا المعلمين و الطلبة في التخطيط و التتظيم و التوجيه و التقويم في تتفيذ خطة التقويم الشامل.كما خلصت النتائج إلى وجــود فروق ذات دلالة إحصائية بين تصور مديري المدارس الابتدائية في تتفيذ خطـــة التقويم الثامل تعزى لمتغير ات: المؤهل العلمي وسنوات الخبرة.

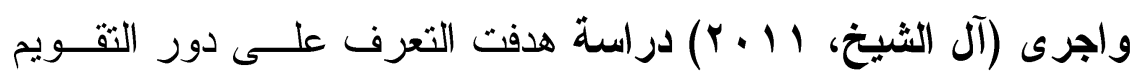
الثامل للمدرسة في تحسين أداء مديري المدارس الابتدائية في المجالين الفنـي 
و الإداري وهي المرحلة التي تم تقويمها، و التعرف على ما حققه التقويم الثـــامل للمدرسة من الأهداف التي رسمتها خاصة فيما يتعلق بأداء مدير المدرسة. وتقديم

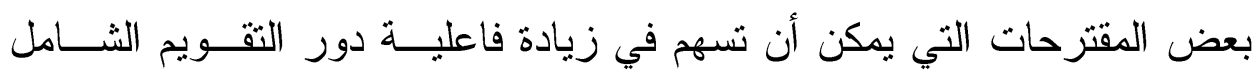
للمدرسة وذلك في ضوء بعض الخبرات العالمية و العربية في هذا المجال. وقـــ توصلت الدر اسة لعدد من النتائج كان من أهمها: أن أفر اد عبنة الدراسة يــرون بشكل عام أن دور التقويم الثامل للمدرسة في تحسين الأداء الفني لمدير المدرسة يأتي بدرجة كبيرة مما يشير إلى فاعلية دور التقويم الثامل للمدرسة كما خلصت الدراسة إلى عدم وجود فروق دالة إحصائيًا بين منوسطات درجات أفراد العينة تعزى لمتغير نوع المؤهل العلمي والدورات التدريبية وسنوات الخبرة في درجة

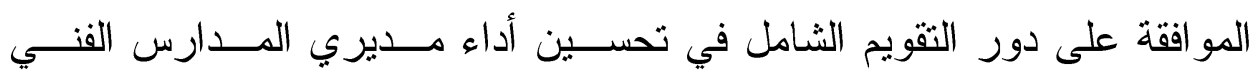
والإداري في منطقة عسير التعليمية.

واستهدفت در اسة لور اوزملائها (Lura et al.,2011) تصميم نظام

شامل لتقييم المعلمين بطريقة فعالة ومستدامة، تتحمـلـل الدولــة فيــهـ مســـؤولية الإشر اف عليه، بحيث يكون الهدف النهائي هو تحسين ممارسات المعلمين فـي

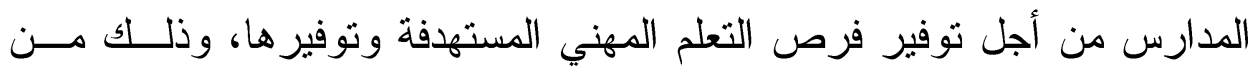
خلال بناء القدرات البشرية على جميع المســتويات حتــى تـتمكن الولايــات و المدارس من التعرف على المعلمين المتفوقين، ودعم المعلمين المحبطين والأقل نجاحًا، ومو اصلة تطوير جميع المعلمين نحو إمكاناتهم الكاملــة. إضـــافة إلـى التحديات المتمثلة في إنشاء أنظمة شاملة لتقييم المعلمين ومنها العلاقة بين القادة و المعلمين. مما يوصي بضرورة بناء التقة وضمان التعاون من أجـل تحقيــق الأهداف المشتركة، بما في ذلك الوقت والصبر والمرونة لتعزيز تطوير الروابط المباشرة بين القادة و المعلمين. 


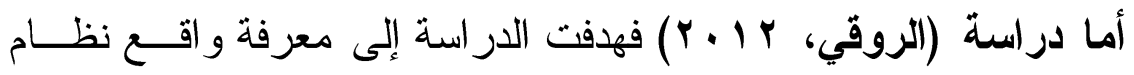
التقويم الثامل المطبق بمدارس التعليم العام بالمملكة العربية السعودية وفق معيار مناسب لتقييم نظام التقويم الثامل في ضوء إدارة الجودة الثاملة، و التعرف على مقترحات أفر اد عينة الدراسة لتطوير نظام التقويم الثامل المطبق بمدارس التعليم العام بالمملكة العربية السعودية ،مع وضع تصور مقتر ح لتطوير نظام التقــويم الثام للمدارس التعليم العام في المملكة العربية السعودية في ضوء نتائج تطبيــق المعيار و الأطر النظرية، و التجارب العالمية وآراء ومقترحسـات أفـــر اد عينـــة

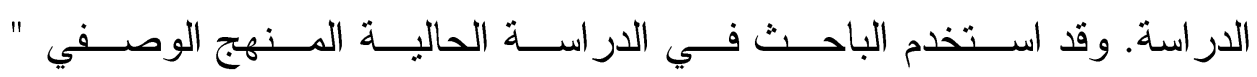
المسحي"،و المنهج الوصفي "الوثائقي"،ومنهج تحليل النظم. وقد تكـــــن مجنـــع

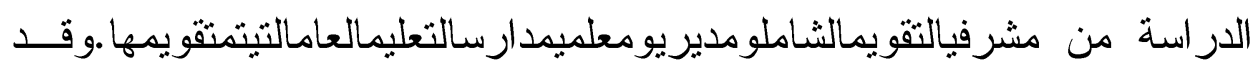
كان من أهم نتائج الدراسة بالنسبة لو اقع نظام التقويم الثامل تميز نظام التقــــيم

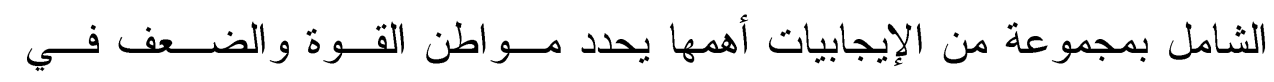
المدارس، ويسهم في تحقيق أهداف السياسة التعليمية. و هدفت در اسة بن عبد الرحمن(ع ا ـ ب). التعرف على اتجاهات المعلمين

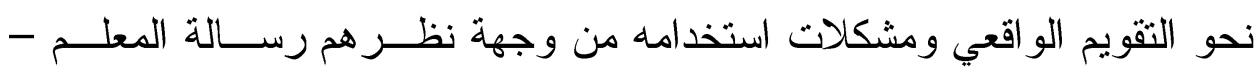

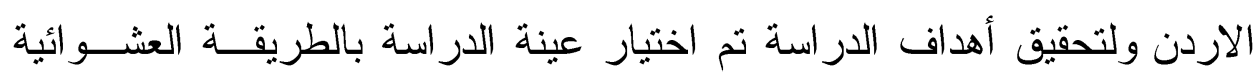

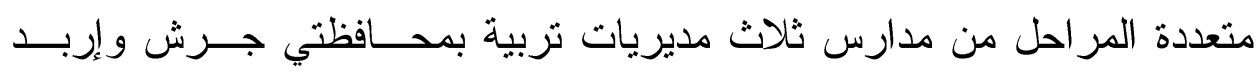
(مديرية جرش، إربد الأولى، بني كنانة) وتكونت عينة الدراسة من (YVT) معلمًا

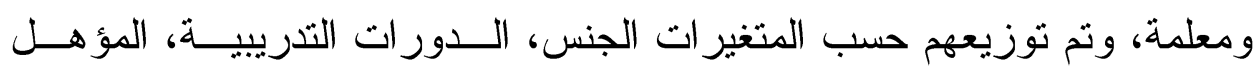
التربوي، الخبرة. وأما أداة القياس فكانت عبارة عن استبانة تشــمل الأجـز اء: معلومات عامة، اتجاهات المعلمين نحو التقويم الواقعي، ومشــكلات اســتخدام

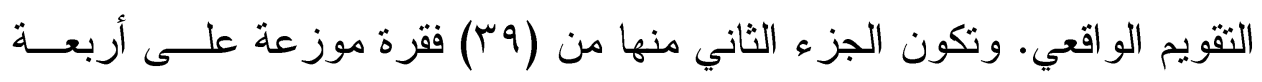

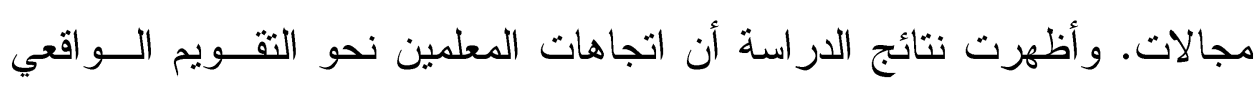


ككل، كانت إيجابية ولكن بدرجة متوسطة، وأظهرت النتائج أن تقدير ات المعلمين لحجم المشكلات التي تواجههم في استخدام التقويم الو اقعي كانت متوسطة أيضًا، كما بينت النتائج وجود فروق ذات دلالة إحصائية عند مستوى الدلالة ((5=0.05

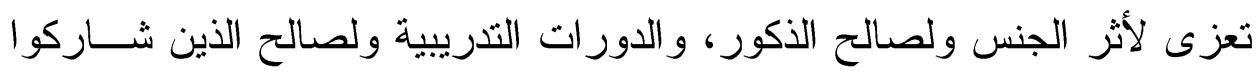
فيها، وذلك على مقياس الاتجاهات، في حين بينت النتائج عدم وجود فروق ذات دلالة إحصائية عند مستوى الدلالة ((0.05=0م تعزى لأثز الجــس، والــدورات التدريبية و المؤهل العلمي، و الخبرة، و التفاعل بينها على مقباس المشكلات.

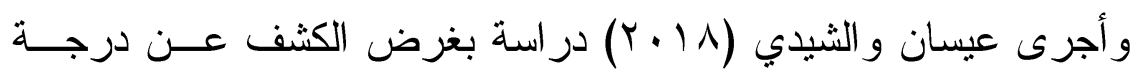
تطبيق الجودة الثاملة في مدارس التعليم ما بعد الأساســي مــن وجهـــة نظـــر المشرفين التربويين و المعلمين الأوائل في سلطنة عمان وتكونت عينة الدراســة

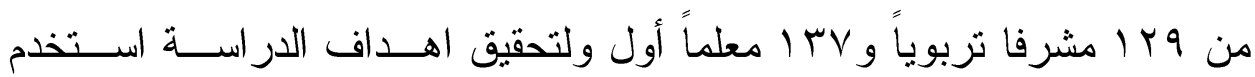
المنهج الوصفي، وطُقت استبانة مكونة من س مبن عبارة وأسفرت نتائج الدراســة عن وجود درجة تطبيق كبيرة لمعايير الجودة في مجــالات المـــوارد البشــرية وشُؤن المتعلمين و التخطيط ، كما أظهرت النتائج وجود فروق دالة في تقديرات أفر اد العينة حول درجة تطبيق معايير الجودة لصالح الاناث في جميع المجالات

\section{تعقيب على الدراسات السابقة:}

من العرض السابق يمكن استنتاج ما توصلت إليه الاراسات السابقة كما يلي: ا - أن التقويم الثامل بأدو اته من حقائب تعليمية وملفات إنجاز من أحدث وسائل تقويم الطلاب.

r- أن للتقويم الشامل أثر كبير في تحسين الأداء وزيادة التحصيل. r- أن التقويم الشامل له فنيات يجب تدريب المعلمين عليها حتى يفهموا المغزى منه. ع - أن التدريب يؤتي ثماره إذا صاحبه اتجاهات إيجابية. 
هـ استفاد الباحث من عرض الدراسات السابقة من بعض التجـــارب العربيـــة و العالمية في نظام التقويم الثامل

وقد خلص الباحث من عرض الدراسات السابقة إلى أنه لا توجد دراسات حتى الآن في حدود اطلاع الباحث تتاولت اتجاهات المعلمين نحو تطبيق التقويم الثامل ومدى تأثر هذه الاتجاهات ببعض المتغيرات الايموغر افية كما بــدركها معلمي التعليم العام و هذا ما انفردت به هذه الدر اسة.

\section{فروض اللدراسةة:}

في ضوء الإطلار النظري و الدراسات السابقة يمكن صــياغة فـروض

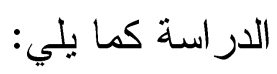
1-تتمايز اتجاهات المعلمين نحو تطبيق التقويم الثامل بالإيجابية. r-لا توجد فروق ذات دلالة إحصائية بين اتجاهات المعلمين نحو تطبيق التقويم الثـامل (الأبعاد، و الدرجة الكلية) تعزى إلى المؤهل العلمي، عـدد ســـوات الخبرة، و المرحلة التعليمية التي يعملون بها. ويتفرع من هذا الفرض، الفروض الفرعية التالية: () لا توجد فروق ذات دلالة إحصائية في اتجاهات المعلمين نحو الثقــويم الثامل بأبعاده الثلاثة ودرجته الكلية باختلاف سنوات الخبرة لديهم. r) لا توجد فروق ذات دلالة إحصائية في اتجاهات المعلمين نحو التقــويم الشامل بأبعاده الثالثة ودرجته الكلية باختلاف مؤهلاتهم العلمية. r) لا توجد فروق ذات دلالة إحصائية في اتجاهات المعلمين نحو الثقــويم

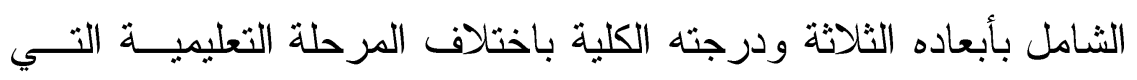
يعملون بها. 
ع) لا يوجد تأثثر ذو دلالة إحصائية لتفاعل ســنوات الخبــرة و المــؤهلات العلمية لدى المعلمين على اتجاهاتهم نحو التقويم الثامل بأبعاده الثلاثــة

$$
\text { ودرجته الكلية. }
$$

0) لا يوجد تأثير ذو دلالة إحصائية لتفاعل سنو ات الخبرة لــدى المعلىـين و المراحل التعليمية على اتجاهاتهم نحو التقويم الثامل بأبعـاده الثلاتـــة

$$
\text { ودرجته الكلية. }
$$

7) لا يوجد تأثير ذو دلالة إحصائية لتفاعل المؤهلات العلمية لدى المعلمين و المر احل التعلمية على اتجاهاتهم نحو التقويم الشامل بأبعـاده الثلاثــة

$$
\text { ودرجته الكلية. }
$$

V) لا يوجد تأثير ذو دلالة إحصائية لتفاعل ســنوات الخبــرة و المــؤهلات

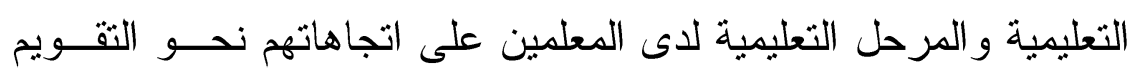
الثامل بأبعاده الثلاثة ودرجته الكلية.

\section{اجرائات اللدراسةة: أولًا: عينة الدراسة:}

تكونت عينة الدر اسة من (99 1) معلمًا من المر احل التعليمية المختلفة نم اختيار ها بالطريقة العشو ائية حيث وزعت وفقًا لمتغير ات البحث ووفقًا للجـدول

\begin{tabular}{|c|c|c|c|c|}
\hline المجموع & ماجستير & بكالوريوس & دبلوم & المؤهل \\
\hline $7 V$ & r & or & M & ابتدائي \\
\hline 0. & . & 0. & . & متوسط \\
\hline$\Lambda r$ & r & VA & r & ثانوي \\
\hline 199 & $\varepsilon$ & 11. & 10 & المجموع \\
\hline
\end{tabular}

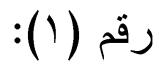

جدول (1) توزيع أفراد العينة وفقًا للمؤهل العلمي والمرحلة التعليمية 
ثانيًا: أدوات الدراسة:

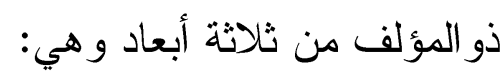

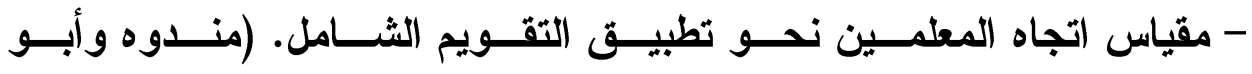
معطي، (25:2007)

أ- الارتقاء بمستوى الطلاب، وكاتت مفرداته:

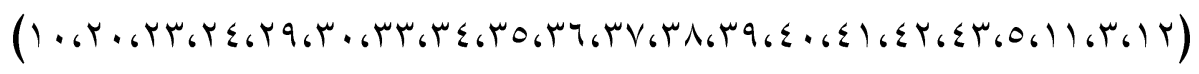
عدد البنود r)

ب-تحسين العملية التعليمية، وكاتت مفرداته:

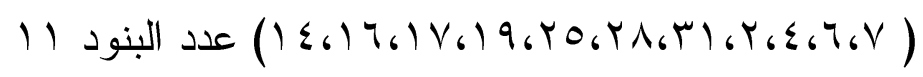
ج-تصسين عملية التقويم، وكاتت مفرداته:

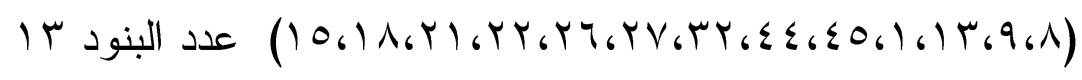

\section{ثالثا: التحقق من صدق وثبات أدوات الدراسة:}

- مقياس اتجاه المعلمين نحو تطبيق التقويم الثامل:

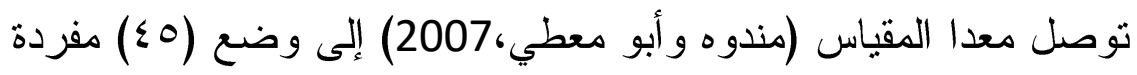

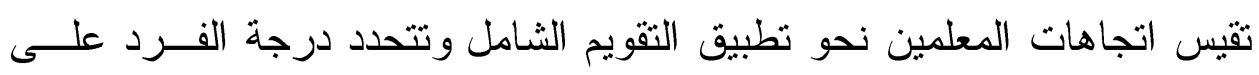

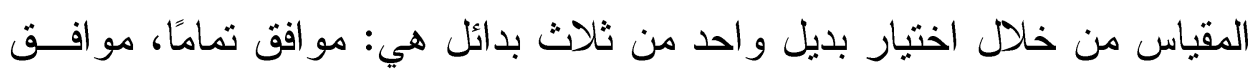

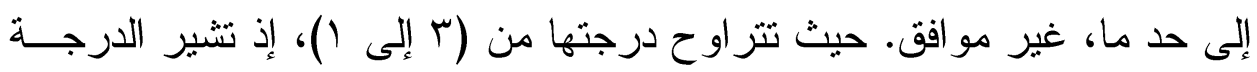
المرتفعة على اتجاه إيجابي. وأن الدرجة المنذفضة تنثير الى الاتجاه السلبي - صدق المحتوى: - ل

للتأكد من صدق المقياس، تم عرضه بصورته الأولية على مجموعة من

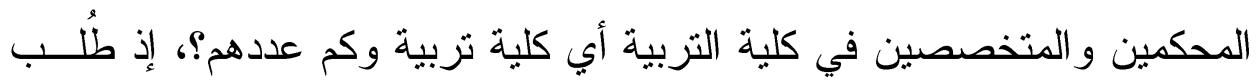

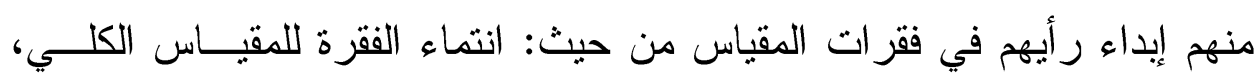

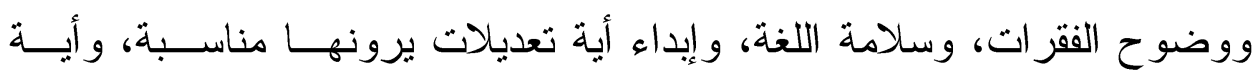


اقتر احات أخرى. وفي ضوء اقتر احات المحكمين و آرائهج، تمت إعادة صـــاغة بعض الفقرات لغويًا للتناسب مع ثقافة المجتمع السعودي، و عدلت بعض الفقرات، كما جرى دمج بعض الفقرات مع بعضها البعض بناءً على اقتر احات المحكمين.

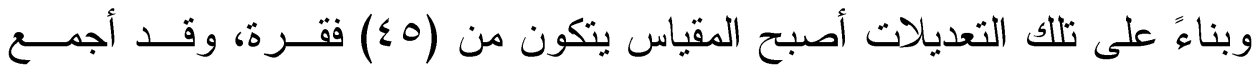
المحكمون على مناسبة المقياس لقياس اتجاه المعلمين نحو تطبيق التقويم الشامل. - الصدق العاملي: - ماني قام الباحث الحالي بإجر اء تحليل عاملي باســتخدام طريقــة المكونــات الرئيسيةsPincipal Components Analysis، مع التدوير المتعامد Varimax Rotation فقر ات المقياس. ويبين الجدول رقم (Y) قيم الجذور الكامنــة، ونســبة التبـــاين المفسر لكل عامل، وكذلك نسبة التباين المفسر التراكمية: الجدول (r) نتائج التحليل العاملي لاستجابات أفراد عينة الاراسة عن مقياس الاتجاه نحو تطبيق التقويم الثامل (0ع فقرة

\begin{tabular}{|c|c|c|c|c|}
\hline عدد الفقرات & نسبة التباين المفسر & نسبة التباين & الإخذر & رقم \\
\hline 21 & 45.1 & 45.1 & 12.35 & 1 \\
\hline 11 & 64.26 & 19.16 & 3.81 & 2 \\
\hline 13 & 80.36 & 16.1 & 3.70 & 3 \\
\hline
\end{tabular}

يتضح من الجدول (Y) وجود ثلاثة عو امل، قيمة الجذر الكامن لكل منهـــا تزيد عن واحد، وتفسر مجتمعة (80.36\%) من التغير الحاصل في البيانات، وقد كانت قيمة الجذر الكامن للعامل الأول (12.35) ويفسر ما نسبته (45.1\%) مــن التباين الكلي، وهذا مؤشر على أنّ المقياس أحادي البعد، لأنّ ما يفسره العامـلـل الأول أكثر من (20\%). حيث يكون المقياس المعدّ أحادي البعد إذا كانت نسـبة

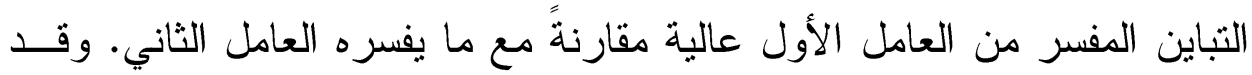


استخلص الباحث من نتائج التحليل العاملي الخاصة بتشبع فقرات المقياس، مــن إمكانية تجميع العوامل في ثلاثة عوامل هي: الاتجاه نحو دور التقويم الثامل في الارتقاء بمستوى الطلاب، الاتجاه نحو دور التقويم الشامل في تحسين العمليــة التعليمية، والاتجاه نحو دور التقويم الثامل في تحسين عملية الثقويم. - ثبات الاتساق الاخلي. وفيه تم حساب معامل ارتباط درجة كل بعد بالدرجة الكلية للمقياس. ويبـين الجدول (ب) قيم معاملات ارتباط درجة كل بعد بالدرجة الكلية للمقياس: جدول (r) قيم معاملات ارتباط درجة كل بعد بالدرجة الكلية للمقياس

\begin{tabular}{|c|c|c|c|}
\hline الاتجاه نحو دور & الاتجاه نحو دور & الاتجاه نحو دور & العامل \\
\hline $0.93 * *$ & $0.88 * *$ & $0.99 * *$ & معامل الارتباط \\
\hline \multicolumn{3}{|c|}{0.01} & مستوى الدلالة \\
\hline
\end{tabular}

يتضح من نتائج الجدول (r) وجود معاملات ارتباط مرتفعة وذات دلالة إحصائية مما يدل على أن المقياس يتمتع بدرجة عالية من الصدق. - الثبات: تم حساب الثبات عن طريق إعادة التطبيـق بفاصـلـل زمنــي مقــداره (أسبو عين) و عن طريق معامل ألفا كرونباخ فكانت النتائج كما يوضحها الجدول

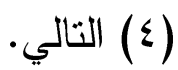


جدول (ع) قيم معاملات الثبات للمقياس

\begin{tabular}{|c|c|c|}
\hline \multicolumn{2}{|c|}{ معامل الثبات بطريقة } & \\
\hline كرونباخ ألفا & إعادة & العامــــــــــــــلـل \\
\hline 0.97 & 0.95 & الاتجاه نحو دور التقويم الثامل في الارتقاء بمستوى \\
\hline 0.77 & 0.78 & الاتجاه نحو دور التقويم الثامل في تحسين العمليـة \\
\hline 0.84 & 0.81 & الاتجاه نحو دور التقويم الثامل في تحسين عمليـة \\
\hline 0.96 & 0.94 & المقياس كاملًا \\
\hline
\end{tabular}

يتضح من الجدول (ع) أن جميع قيم معاملات الثبات جيدة ومرتفعة، إذ تعدّ هذه القيمة مؤشرًا جيدًا على تمتع المقياس بمعامل ثبــات مناســب لتحقيــق

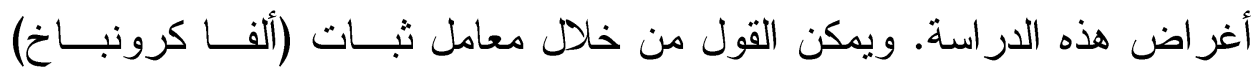
المحسوب ومعامل ثبات الإعادة أنّ المقياس المعد يتمتع بثبات عالٍ، وأنه يمتــاز بخصائص سيكومترية جيدة، وبالتالي يمكن الاعتماد عليه في الحصــول علـى

$$
\text { - نتائج دقيقة. }
$$

استخدم الباحث في إجر اء الدر اسة واستخر اج النتائج بعــض الأســاليب الإحصائية التالية.

- التكر ار ات و النسب المئوية و المتوسطات الحسابية و الانحر افات المعيارية. - اختبار كاي تربيع (X) لحسن المطابقة لكل عبارة مــن عبــار ات مقيــاس اتجاهات المعلمبن. 
- تحليل التباين الثلاثي (التصميم العاملي س×ب×r) للكثف عن دلالة الفروق إحصائيًا في المتغير ات التابعة وفي ضوء التفاعلات الثنائية و الثلاثية بــين تلك المتغير ات.

\section{تخليل نتائج الدراسة وتفسيرها:}

تحليل نتائج الفرضين الأول و الثاني وتفسير هما: أوثًا: النتائجج المتعلقة بالقرض الاول:

- تثمايز اتجاهات المعلمين نحو تطبيق التقويم الثامل بالإيجابية.

- النتائج الخاصة بمعلمي المرحلة الابتدائية:

استخدم الباحث قيمة التكر ار ات ومدى موافقة معلمي المرحلة الابتدائيــة

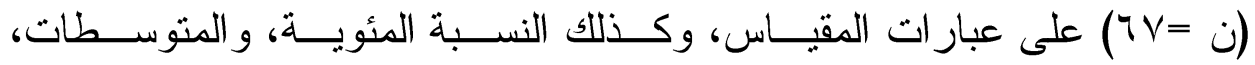

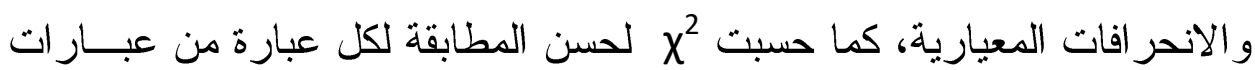
المقياس وجاءت النتائج كما هو موضح في الجدول رقم (0): 


\begin{tabular}{|c|c|c|c|c|c|c|c|c|c|c|c|}
\hline جاه & مقياس & على فُ & 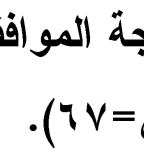 & باس ود بائية & ردات ال ملة & 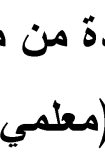 & ح لكل مفر & ثيمة & & ل (0) التكر ارات والتسب الا & \\
\hline 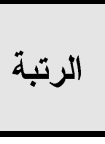 & الموجة افقة & الالالة & قيمة & الالمحر افياري & المتوسط & موافق & موافق & غوافيز & $ت$ & 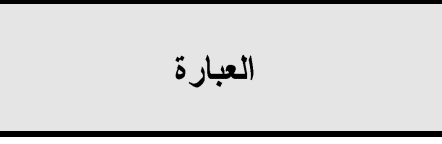 & 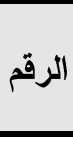 \\
\hline \multirow{2}{*}{$1 \cdots$} & موافق لحد & \multirow{2}{*}{$\ldots \ldots *$} & \multirow{2}{*}{$11.70 \mathrm{~V}$} & \multirow{2}{*}{. .70} & \multirow{2}{*}{ r.. } & $1 \varepsilon$ & rq & $1 \varepsilon$ & $ت$ & \multirow{2}{*}{ يعالج عيوب طرق التقويم } & \multirow{2}{*}{1} \\
\hline & ما & & & & & $r \cdot . q$ & OA.r & $r \cdot .9$ & $\%$ & & \\
\hline \multirow{2}{*}{ V.. } & موافق لحد & \multirow{2}{*}{. $.7 \mathrm{~V}$} & \multirow{2}{*}{$0 . \varepsilon \cdot r$} & \multirow{2}{*}{.$v r y$} & \multirow{2}{*}{ r...OV } & $r \cdot$ & M & 17 & $ت$ & \multirow{2}{*}{ له إيجابيات كثيرة في تحسين } & \multirow{2}{*}{ r } \\
\hline & ما & & & & & rq.9 & $\varepsilon ५ . r$ & rr.q & $\%$ & & \\
\hline \multirow{2}{*}{$1 .}$. & موافت لحد & \multirow{2}{*}{$\cdots+1 r$} & \multirow{2}{*}{$\wedge . \vee 14$} & \multirow{2}{*}{$\because \vee 19$} & \multirow{2}{*}{ r.rrA } & rv & rq & 11 & 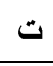 & \multirow{2}{*}{ يمثل عبء إضافي على كاهل } & \multirow{2}{*}{$r$} \\
\hline & ما & & & & & $\varepsilon \cdot r$ & $\varepsilon r . r$ & 17.8 & $\%$ & & \\
\hline \multirow{2}{*}{7.} & موافق لحد & \multirow{2}{*}{. $.7 \mathrm{~V}$} & \multirow{2}{*}{$0 . \varepsilon \cdot r$} & \multirow{2}{*}{.VYr } & \multirow{2}{*}{ r...09 } & $r \cdot$ & r & 17 & $ت$ & \multirow{2}{*}{ يتعارض مع الجدول الزمني لتنفيذ } & \multirow{2}{*}{$\varepsilon$} \\
\hline & L & & & & & ra.9 & $\varepsilon 7 . r$ & $r r . q$ & $\%$ & & \\
\hline \multirow{2}{*}{$r \cdot . \cdot$} & موافق لحد & \multirow{2}{*}{. $.1 T V$} & \multirow{2}{*}{ r.9v. } & \multirow{2}{*}{. v० } & \multirow{2}{*}{1.170} & 10 & $r \wedge$ & $r \varepsilon$ & $ت$ & \multirow{2}{*}{ يهتم بالثكل على حساب المادة } & \multirow{2}{*}{ • } \\
\hline & L & & & & & Yr.E & $\varepsilon 1.1$ & ro.ı & $\%$ & & \\
\hline$\omega$ & موافق لحد & & $0 \quad y=1$ & & 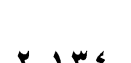 & $r r$ & $r$ & $1 \varepsilon$ & $ت$ & يتطلب إعادة بناء المناهج بطريقة & \\
\hline 1. & ما & $\cdots+$ & 0.81 & •. & 1.118 & $r \varepsilon . r$ & $\varepsilon \varepsilon . \wedge$ & $r \cdot . q$ & $\%$ & مناسبة. & 1 \\
\hline 11. & موافت لحد & I ry & r gy. & $y<1$ & 1910 & 11 & $r$ & 19 & $ت$ & يحسن توظيف المقررات & y \\
\hline 1 & ما & 年 & . & 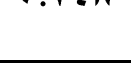 & 1. & r.. & $\varepsilon \varepsilon . \wedge$ & r^.乏 & $\%$ & الار اسية. & s \\
\hline
\end{tabular}




\begin{tabular}{|c|c|c|c|c|c|c|c|c|c|c|c|}
\hline الرتبة & المو افقة & الدلالة & قيمة & الالمعر اف المياري & المسابي & تموافق & إلى حد مافق & غير & $ت$ & العبارة & الرقم \\
\hline \multirow{2}{*}{$11 \ldots$} & موافق لحد & \multirow{2}{*}{$\ldots \ldots * *$} & \multirow{2}{*}{$17.0 \cdot V$} & \multirow{2}{*}{. } & \multirow{2}{*}{1.910} & $1 \varepsilon$ & $r \wedge$ & 10 & $ت$ & \multirow{2}{*}{ يجعل أسرة المدرسة تعمل في } & \multirow{2}{*}{$\wedge$} \\
\hline & ما & & & & & $r \cdot . q$ & $04 . V$ & YY.E & $\%$ & & \\
\hline \multirow{2}{*}{ r.. } & موافق لحد & \multirow{2}{*}{$\cdot r \varepsilon}$. & \multirow{2}{*}{ Y.^9५ } & \multirow{2}{*}{$\because \vee 9$} & \multirow{2}{*}{ r.19દ } & $r v$ & $r \leq$ & 17 & 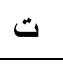 & \multirow{2}{*}{ تفرض على المعلم ضرورة } & \multirow{2}{*}{9} \\
\hline & 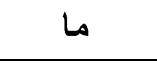 & & & & & $\varepsilon \cdot r$ & ro.^ & rr.q & $\%$ & & \\
\hline \multirow{2}{*}{$9 .}$. & موافق لحد & \multirow{2}{*}{$\cdots 9 \ldots$} & \multirow{2}{*}{$r .9$} & \multirow{2}{*}{$\cdot . \Lambda \cdot V$} & \multirow{2}{*}{ r.. IE } & rr & $r \leqslant$ & rl & $ت$ & \multirow{2}{*}{ يقلل من مشكلة الدروس } & \multirow{2}{*}{1.} \\
\hline & ما & & & & & rr.^ & $r \bullet . \wedge$ & M. & $\%$ & & \\
\hline \multirow{2}{*}{7.} & موافق لحد & \multirow{2}{*}{ ***. . \& } & \multirow{2}{*}{$11.1 \% \varepsilon$} & \multirow{2}{*}{. .794} & \multirow{2}{*}{$r . .0 q$} & 11 & ro & $1 \varepsilon$ & $ت$ & \multirow{2}{*}{ بستخلم فنيات بسيطة في تقويم } & \multirow{2}{*}{11} \\
\hline & ما & & & & & r.. & Or.r & $r \cdot . q$ & $\%$ & & \\
\hline \multirow{2}{*}{ rr.. } & موافق لحد & \multirow{2}{*}{$\cdots \wedge \wedge$} & \multirow{2}{*}{ צ.Аๆ } & \multirow{2}{*}{$\cdot v 0}$. & \multirow{2}{*}{ I.Aro } & $1 \varepsilon$ & rA & ro & $ت$ & \multirow{2}{*}{ يربط المدرسة بالمنزل والمجتمع. } & \multirow{2}{*}{ Ir } \\
\hline & ما & & & & & $r \cdot .9$ & $\varepsilon 1 . \wedge$ & $r v . r$ & $\%$ & & \\
\hline 0. & موافق لحد & $* * \ldots 1$ & $9 . y \cdot 1$ &.$v \cdot r$ & $r . \vee v \leqslant$ & 19 & $r \varepsilon$ & $1 \varepsilon$ & $ت$ & بستخدم أساليب متعددة في تقويم & $1 \mathrm{~m}$ \\
\hline . & 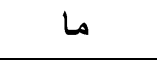 & ren & r & . & re & r^.乏 & $\bullet \cdot v$ & $r \cdot .9$ & $\%$ & الطلاب. & r \\
\hline 19. & موافق لحد & . $\{11$ & $1 \leqslant 7 \pi$ & - $\Lambda . \vee$ & $1 \wedge \Lambda$. & 11 & $r r$ & ry & $ت$ & علاقة الطالب بالمبلى & $1 \leqslant$ \\
\hline 10 & ما & ren & r & r & 1.0. & rq.9 & $r \varepsilon . r$ & r^.^ & $\%$ & " & - \\
\hline Y... & موافق لحد & $* * \ldots r$ & Irgro & . . Vrr & $1.7 \varepsilon 1$ & $1 \cdot$ & $r r$ & $r \varepsilon$ & $ت$ & يجب تعميمه على كل المراحل لأنه & 10 \\
\hline & 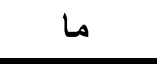 & & & & & $1 \varepsilon .9$ & $r \varepsilon . r$ & $0 \cdot v$ & $\%$ & يعد الطالب لسوق العمل. & 10 \\
\hline
\end{tabular}




\begin{tabular}{|c|c|c|c|c|c|c|c|c|c|c|c|}
\hline الرتبة & درجة المو افقة & الالالة & قيمة & الإنحر اف المعياري & المتوسط & تموافق & موافق & غير & $ت$ & 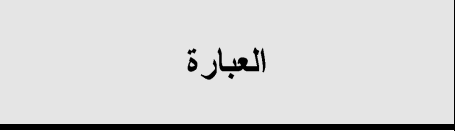 & 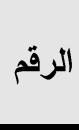 \\
\hline \multirow{2}{*}{ Ir.. } & \multirow{2}{*}{ موافق لحد } & \multirow[t]{2}{*}{$* * \ldots 1$} & \multirow{2}{*}{ I \&.OTV } & \multirow{2}{*}{. $.7 V r$} & \multirow{2}{*}{$1.9 V$} & $1 \varepsilon$ & rv & 17 & $ت$ & \multirow{2}{*}{ يرفع من جودة العملية التعليمية. } & \multirow{2}{*}{17} \\
\hline & & & & & & $r \cdot .9$ & $00 . r$ & rr.q & $\%$ & & \\
\hline \multirow{2}{*}{$1 \wedge}$. & \multirow{2}{*}{ موافق لحد } & \multirow{2}{*}{$\because 10$} & \multirow{2}{*}{$r . \vee 91$} & \multirow{2}{*}{$\because v \circ r$} & \multirow{2}{*}{1.91.} & 17 & rq & rr & $ت$ & \multirow{2}{*}{ يكثف عن مواهب وقدرات } & \multirow{2}{*}{ iv } \\
\hline & & & & & & $r r . q$ & $\varepsilon r . r$ & r.A & $\%$ & & \\
\hline \multirow{2}{*}{ r.. } & \multirow{2}{*}{ موافق لحد } & \multirow{2}{*}{. $.17 \varepsilon$} & \multirow{2}{*}{ r.TIr } & \multirow{2}{*}{$\because \vee \vee}$. & \multirow{2}{*}{ r.19દ } & rq & rq & 10 & $ت$ & \multirow{2}{*}{ يقلل من رهبة الامتحانات } & \multirow{2}{*}{11} \\
\hline & & & & & & $\mu \wedge . \wedge$ & r^.^ & rY.E & $\%$ & & \\
\hline \multirow{2}{*}{$r \varepsilon \ldots$} & \multirow{2}{*}{ موافق لحد } & \multirow{2}{*}{$\cdots r 1$} & \multirow{2}{*}{ V.VYI } & \multirow{2}{*}{.VYr } & \multirow{2}{*}{$1.1 \cdot 9$} & ir & $r$ & ro & $ت$ & \multirow{2}{*}{ يعوق سير العملية التعليمية } & \multirow{2}{*}{19} \\
\hline & & & & & & 18.9 & $\varepsilon \varepsilon . \wedge$ & rV.r & $\%$ & & \\
\hline \multirow{2}{*}{ r... } & \multirow{2}{*}{ موافق لحد } & \multirow[t]{2}{*}{$* * \ldots v$} & q $\wedge \wedge 1$ & $-x+1$ & 110 & ir & $r r$ & rr & 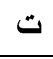 & يهتم بالعمليات العقلية العليا لاى & $r$ \\
\hline & & & 1 & r & 1. & 18.9 & $\varepsilon q . r$ & rr.A & $\%$ & الطلاب. & 10 \\
\hline 1.2 & موافق لحد & r ro & $r 9 \wedge 0$ & 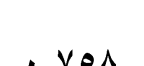 & $r$ & 19 & rq & 19 & $ت$ & يزيد من اعتماد الطلاب على & $r 1$ \\
\hline , & ما & 开 & 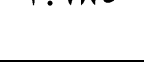 & 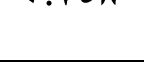 & 1. & r^.乏 & $\varepsilon \Psi . \mu$ & r^.乏 & $\%$ & المعلم. & 1 \\
\hline$\Lambda$. & موافق لحد & $* * \ldots r$ & Ir $07 \mathrm{Y}$ & .90 & 5.19 & 17 & rq & 10 & $ت$ & يزيد من تعاون الطلاب مع بعضهم & $r r$ \\
\hline$\ldots$ & ما & & 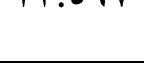 & (n) & 年 & $r r . q$ & or.v & YY.E & $\%$ & البعض. & 1 \\
\hline$\varepsilon$. & موافق لحد & . r & $y \leqslant \gamma \wedge$ & - Yru & $r 11 \varepsilon$ & rr & r & $1 \varepsilon$ & $ت$ & يجعل الطالب أكثر حرية في أداء & $r \mu$ \\
\hline$\because$ & & $\because 1$ & not. & (ט) & 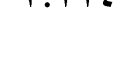 & rr.A & $\varepsilon ५ . r$ & $r \cdot . q$ & $\%$ & ما يحب. & 1 \\
\hline
\end{tabular}




\begin{tabular}{|c|c|c|c|c|c|c|c|c|c|c|c|}
\hline الرتبة & المو (فقة & الدلالة & قيمة & الالمعراف & المسابي & تموافق & إلى حد مافق & غير & $ت$ & العبارة & الرقم \\
\hline \multirow{2}{*}{$1 \varepsilon \ldots$} & \multirow{2}{*}{ موافق لحد } & \multirow[t]{2}{*}{$* * \ldots 9$} & \multirow{2}{*}{$q . r \leq r$} & \multirow{2}{*}{$\cdot v \cdot \theta$} & \multirow{2}{*}{$1.90 r$} & 10 & $r \varepsilon$ & 11 & $ت$ & \multirow{2}{*}{ 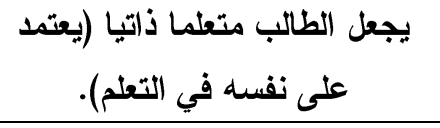 } & \multirow{2}{*}{$r \varepsilon$} \\
\hline & & & & & & rr.s & $0 . V$ & r.. & $\%$ & & \\
\hline \multirow{2}{*}{$9 . \cdot$} & \multirow{2}{*}{ موافق لحد } & \multirow{2}{*}{ מצr } & \multirow{2}{*}{ r.lvq } & \multirow{2}{*}{.$\vee \vee \neg ~$} & \multirow{2}{*}{ r... Is } & $r \cdot$ & $r \wedge$ & 19 & $ت$ & \multirow{2}{*}{ يكثف باستمرار عن مدى تقدم } & \multirow{2}{*}{ ro } \\
\hline & & & & & & rq.9 & $\varepsilon 1 . \wedge$ & r^.乏 & $\%$ & & \\
\hline \multirow{2}{*}{$11 \ldots$} & موافق لحد & \multirow{2}{*}{$\cdot \cdot \varepsilon r$} & \multirow{2}{*}{7.199} & \multirow{2}{*}{$\because \vee Y \wedge$} & \multirow{2}{*}{1.910} & iv & rr & 11 & $ت$ & \multirow{2}{*}{ يجعل الطالب أكثر ارتباطا بالواقع. } & \multirow{2}{*}{ r } \\
\hline & ما & & & & & ro.乏 & $\varepsilon \vee . \wedge$ & $r 7.9$ & $\%$ & & \\
\hline \multirow{2}{*}{19.} & موافق لحد & \multirow{2}{*}{$\cdots+r q$} & \multirow{2}{*}{ 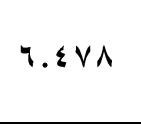 } & \multirow{2}{*}{$\because \vee Y \wedge$} & \multirow{2}{*}{$1 . \wedge \wedge$. } & $1 \varepsilon$ & r & $r r$ & $ت$ & \multirow{2}{*}{ يجعل عملية التقويم أكثر } & \multirow{2}{*}{ rV } \\
\hline & ما & & & & & $r \cdot .9$ & $\varepsilon ५ . r$ & r.ı.^ & $\%$ & & \\
\hline \multirow{2}{*}{$10 .}$. & موافق لحد & \multirow{2}{*}{$* * \ldots$} & \multirow{2}{*}{$19 .+10$} & \multirow{2}{*}{$. .7 \leqslant \wedge$} & \multirow{2}{*}{$1.9 \varepsilon$} & ir & rq & 17 & $ت$ & يحتفظ بسجل إنجاز الطالب ليكون & rA \\
\hline & ما & & & & & 18.9 & OA.r & rr.q & $\%$ & دافعا باستمرار للتحسن. & 年 \\
\hline 11. & موافق لحد & - I wy & r gy. & $y<A$ & $19 \wedge 0$ & 11 & $r$ & 19 & $ت$ & يجعل الطالب أكثر فاعلية داخل & rq \\
\hline 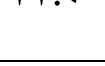 & ما & 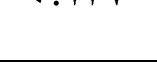 & 年 & (n) & 1.010 & r..9 & $\varepsilon \varepsilon . \wedge$ & r^.乏 & $\%$ & الفصل الدراسي. & r \\
\hline 17. & موافق لحد & - 1. & $=0, y$ & $y \leqslant \varepsilon$ & I a ro & 17 & $r$ & Y & $ت$ & يدفع الطالب لممارسة أنثطة & 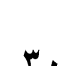 \\
\hline $1 .$. & ما & 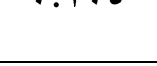 & 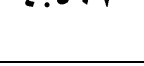 & 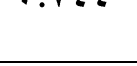 & 1. & $r r . q$ & $\varepsilon \varepsilon . \wedge$ & M.r & $\%$ & مختلفة داخل المدرسة. & 10 \\
\hline Ir.. & موافق لحد & $* * \ldots$ & $r r . \varepsilon q \mu$ & .9 Y & $1.9 V$ & ir & $\leqslant 1$ & $1 \leq$ & $ت$ & يحسن من مستوى الأداء داخل & $\mu_{1}$ \\
\hline & ما & & & & & 18.9 & $11 . r$ & $r \cdot . q$ & $\%$ & المدرسة. & \\
\hline
\end{tabular}




\begin{tabular}{|c|c|c|c|c|c|c|c|c|c|c|c|}
\hline 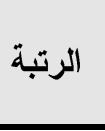 & درجة المو افقة & الالالة & قيمة & الإنحر اف المعياري & المتوسط & تموافق & موافق & غير & $ت$ & 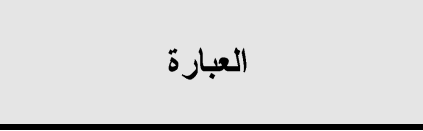 & 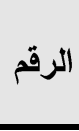 \\
\hline \multirow{2}{*}{ ro.. } & \multirow{2}{*}{ موافق لحد } & \multirow{2}{*}{$\cdots r \Delta$} & \multirow{2}{*}{ V.rVr } & \multirow{2}{*}{$\because v r q$} & \multirow{2}{*}{1.291} & ir & rq & ri & $ت$ & \multirow{2}{*}{ أنسب طريقة للتقويم في ظل } & \multirow{2}{*}{ rr } \\
\hline & & & & & & 18.9 & $\varepsilon r . r$ & r^.^ & $\%$ & & \\
\hline \multirow{2}{*}{$1 \wedge}$. & \multirow{2}{*}{ موافق لحد } & \multirow{2}{*}{$\ldots 0 \leqslant$} & \multirow{2}{*}{$0 . \wedge 01$} & \multirow{2}{*}{$\cdot V r r$} & \multirow{2}{*}{1.91.} & 10 & r & YI & $ت$ & \multirow{2}{*}{ يقدم تغذية راجعة مناسبة عن } & \multirow{2}{*}{$r r$} \\
\hline & & & & & & r.t.z & $\varepsilon ५ . r$ & MI.r & $\%$ & & \\
\hline \multirow{2}{*}{$r \cdot}$. & \multirow{2}{*}{ موافق لحد } & \multirow{2}{*}{$\cdots 11$} & \multirow{2}{*}{ ^..9. } & \multirow{2}{*}{$\because \times 10$} & \multirow{2}{*}{1.140} & ir & rr & rr & $ت$ & \multirow{2}{*}{ يزيد من إقبال الطالب على } & \multirow{2}{*}{$r \varepsilon$} \\
\hline & & & & & & 19.8 & $\varepsilon V . \Lambda$ & r.A. & $\%$ & & \\
\hline \multirow{2}{*}{$1 \wedge}$. & \multirow{2}{*}{ موافق لحد } & \multirow{2}{*}{$* * \ldots$} & \multirow{2}{*}{$10 . Y 0 \varepsilon$} & \multirow{2}{*}{.741} & \multirow{2}{*}{1.91.} & ir & rv & 11 & $ت$ & \multirow{2}{*}{ يـتم بجوانب شخصية الطالب } & \multirow{2}{*}{ ro } \\
\hline & & & & & & 18.9 & $00 . r$ & r..9 & $\%$ & & \\
\hline \multirow{2}{*}{$r \cdot}$. & \multirow{2}{*}{ موافق لحد } & \multirow{2}{*}{$\cdots 11$} & 1. 9. & 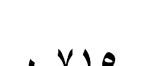 & 1070 & ir & rr & rr & $ت$ & & \\
\hline & & & N. & . & 1.010 & 19.8 & $\varepsilon \vee . \wedge$ & rr.A & $\%$ & يح & 11 \\
\hline 17. & موافق لحد & & 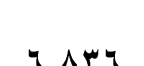 & - $y r \leqslant$ & $19 r$ & 10 & rr & $r \cdot$ & 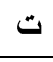 & يستثر طاقات الطلاب بطريقة & ey \\
\hline . & ما & 等 & 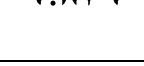 & 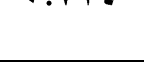 & 1. & rr.s & $\varepsilon V . \wedge$ & rq.9 & $\%$ & جيدة. & $1 \mathrm{r}$ \\
\hline 11 & موافق لحد & $=:$ & $19<4$ & $14 \leqslant 0$ & 191 & 11 & ma & iv & $\uplus$ & يوفر قرا من المتابعة لأداء & $\hat{s}$ \\
\hline$\ldots$ & ما & -... & 1. & $\theta 0$ & 1.0 & 17.8 & OA.Y & Yo. $\varepsilon$ & $\%$ & المعلمين. & 10 \\
\hline & موافق لحد & & & & & iv & rr & 11 & $ت$ & & \\
\hline $11 .$. & ما & $\because 2 r$ & 7.149 & $\because$ Vर & 1.910 & ro.s & $\varepsilon \vee . \wedge$ & $r 4.9$ & $\%$ & وب نفير الطلاب. & $r 4$ \\
\hline
\end{tabular}




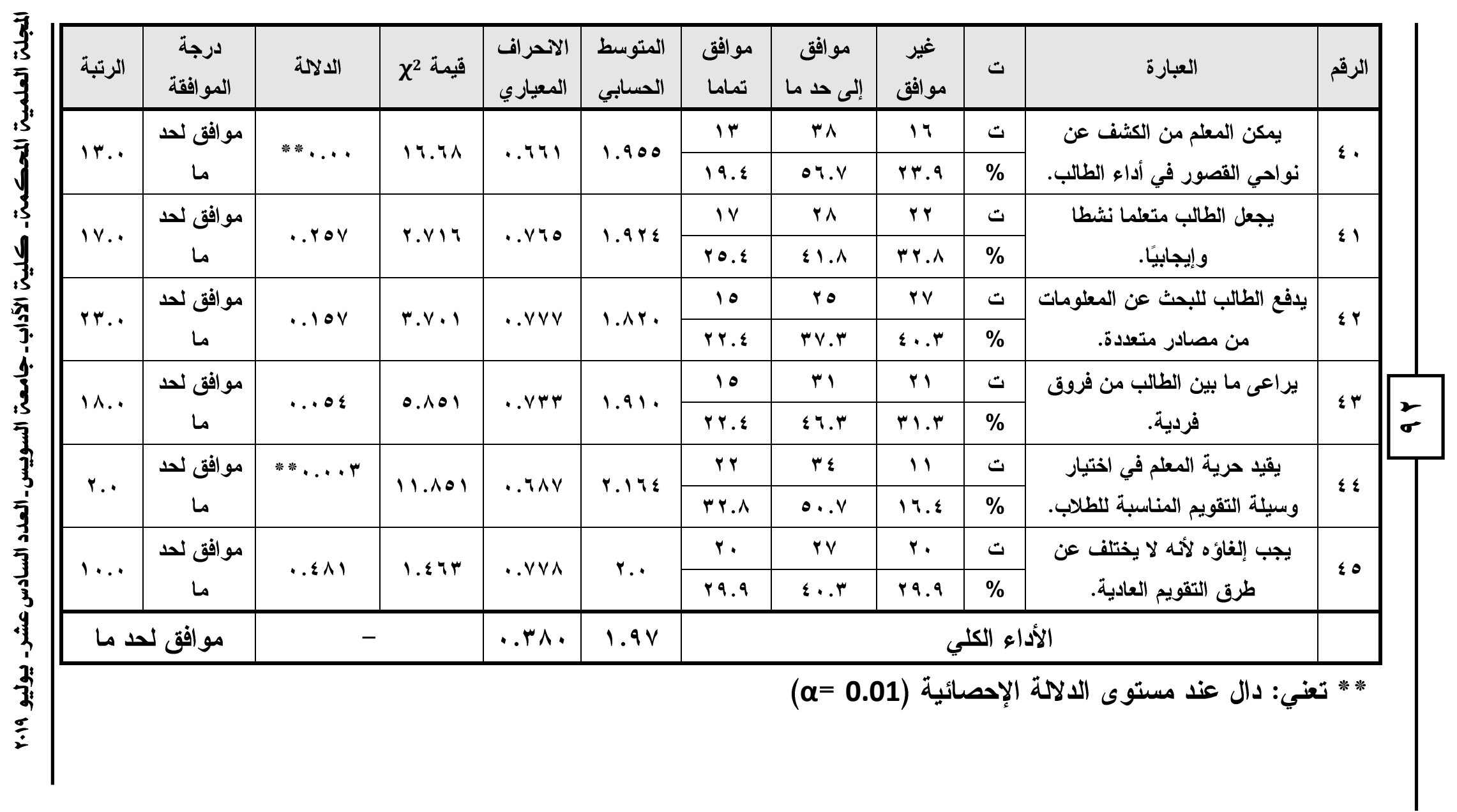


|تضح من الجدول ه: أنّ جميع فقر ات المقياس قد حازت على درجة مو افق لحد ما من التقدير.

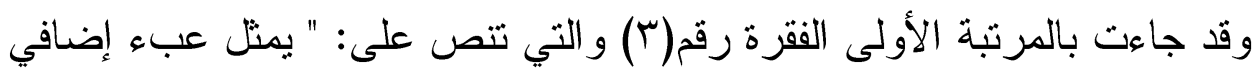

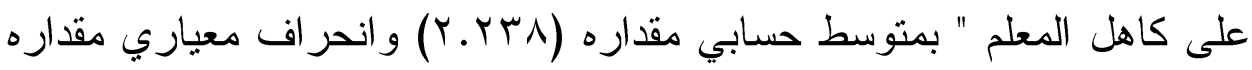

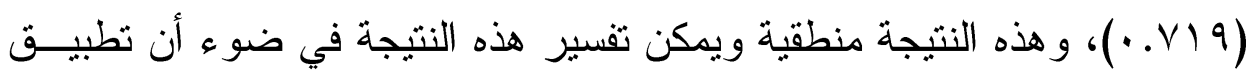
التقويم الثامل فكرة مستحدثة على عكس ما اعتاد عليه المعلمون، ويتطلب جهذًا

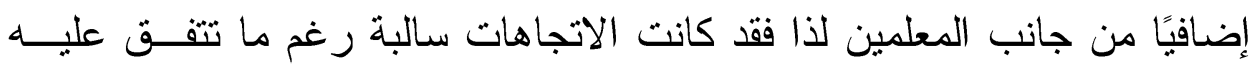

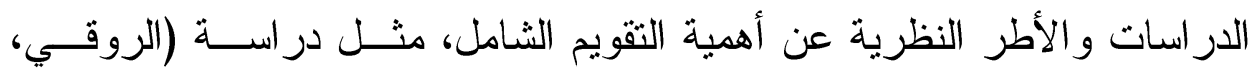

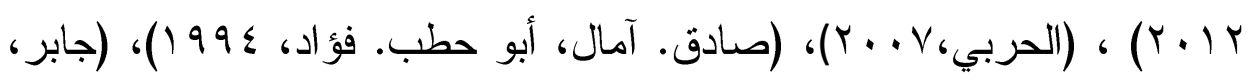

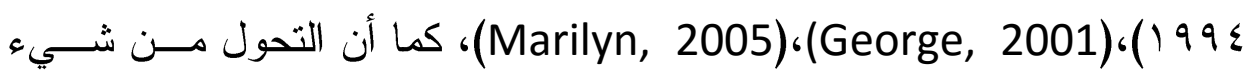

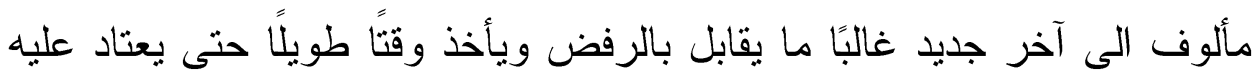
الأفر اد كون هنالك العديد من المنطلبات تلقى على عاتق معلمي المرحلة الابتدائية

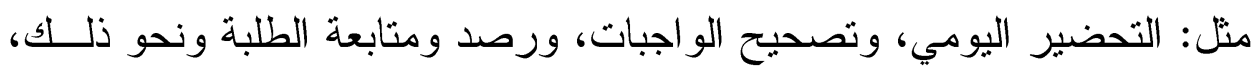

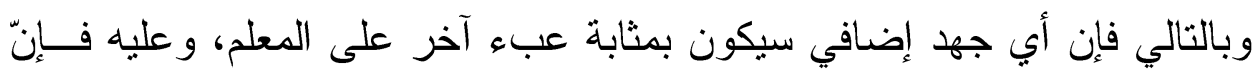

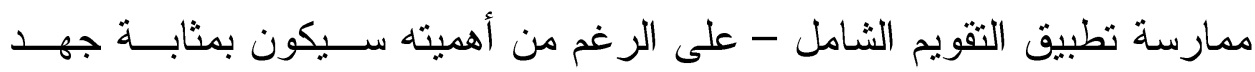

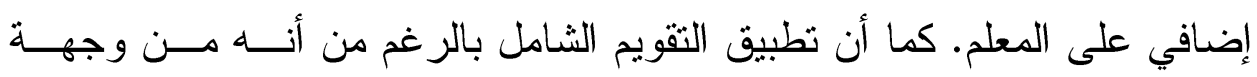

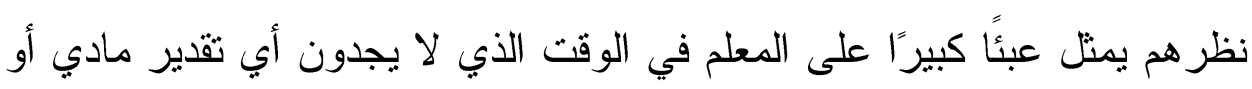

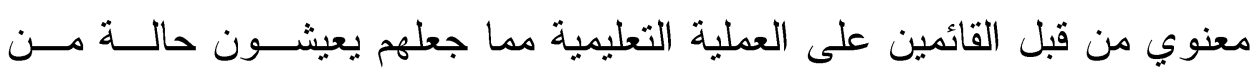
الاحباط،كما أنهم جميعًا لم يندربوا التدريب الكافي على تطبيقه أو توظيفه بطريقة

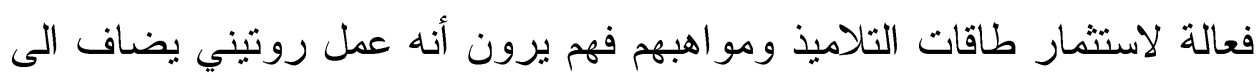

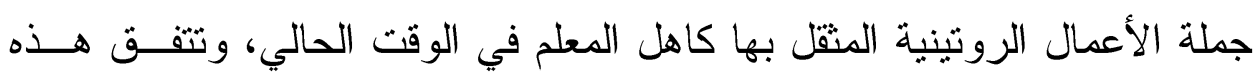

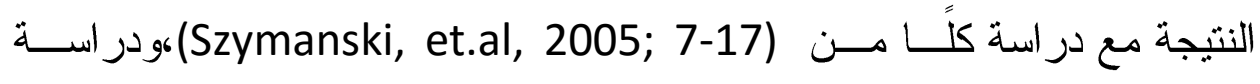

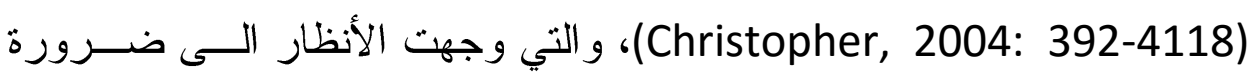


تدريب المعلمين التذريب الكافي على تطبيق التقــويم الثــامل وكــذلك تـوفير الإمكانات اللازمة;فالمؤهل التعليمي العالي بالرغم من أن الحاصلين عليه تلقـــوا

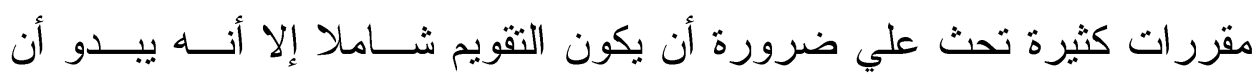
معوقات هذا النظام الجديد كانت أقوى أثرًا على المعلمين.

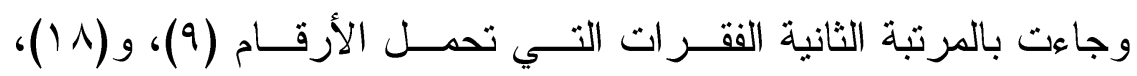
و(ع \&)، وقد نصت الفقرة رقم (9) على: "يفرض على المعلم ضرورة تحســين طريقة تدريسه"، وهذا يتأتى من خلال التقويم الثامل بجميع عناصره و أدواتــه، فهنالك طريقة تدريس تلائم موقف تعليمي معين، في حين هناك طريقة تـدريس أخرى تلائم موقف تعليمي آخر، الأمر الذي يفرض على المعلـــم مــن اختيـــار الطريقة المناسبة في التقويم تبعًا لاختلاف المو اقف التعليمية، مما يمهذ الطريـق أمام المعلم للوقوف على طريقة تدريسه وتقويمها. ونصت الفقـرة رقــم (1) على: "يقلل من رهبة الامتحانات النهائية"، كونه في التقويم الثامل يكون تقـويم الطلبة باستخدام أدوات قياس متعددة وفي مواقف متتو عة أيضًا. ونصت الفقــرة رقم (ء؟) على: "يقيد حرية المعلم في اختيار وسيلة التقويم المناسبة للطــلاب"، وقد يكون السبب في ذلك كون المعلمين ينتهجون طريقة محددة لتقــويم طلبــة المرحلة الابتدائية، كما أن أدوات التقويم في التقويم الشامل متتوعة، وبالتالي قد تجعل المعلم في هذه المرحلة في حيرة من أمره عند اختبــار وســيلة التقــويم المناسبة، كونه يريد وسيلة تقويم تتلاعم مع طلبة المرحلة الابتدائية. (الأخضــر، $(r \cdot 1$

ويمكن أن نستتتج من هذه النتيجة أنه ينبخي تهيئة المعلمين واســنطلاع آر ائهم قبل تطبيق أي نظام جديد لضمان وجود اتجاهات ايجابية كافية لتفعيل هذا النظام. 


\section{النتائج الخاصة بمعلمي المرحلة المتوسطة:}

تم حساب تكرارات مدى مو افقة معلمي المرحلة المتوسطة على عبار ات

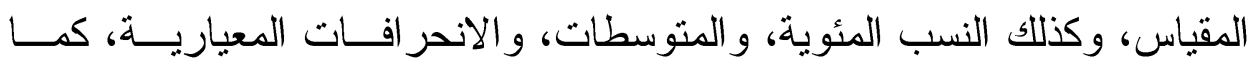
حسبث قيمة X2لحسن المطابقة لكل عبارة من عبار ات مقياس اتجاهات المعلمين في المرحلة المتوسطة (ن=.0) نحو تطبيق الثقويم الثامل كما هو موضح فـي الجدول رقم(؟) التالي. 


\begin{tabular}{|c|c|c|c|c|c|c|c|c|c|c|c|}
\hline \multicolumn{12}{|c|}{ 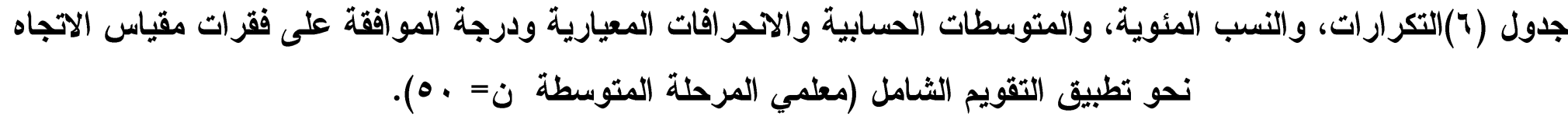 } \\
\hline الرتبة & درجة & الدلامة & قيمة & الانحراف & المتوسط & موافق & موافق إلى & غوافث & $ت$ & 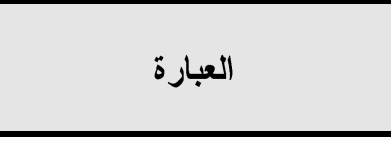 & الرقم \\
\hline \multirow{2}{*}{$1 \wedge}$. & موافق لحد & \multirow{2}{*}{$\ldots \circ r$} & \multirow{2}{*}{$0.9 r}$. & \multirow{2}{*}{$\cdot \vee \backslash \wedge$} & \multirow{2}{*}{$1 . \wedge 1$} & 1. & $r \varepsilon$ & 17 & $ت$ & \multirow{2}{*}{ يعالج عيوب طرق التقويم } & \multirow{2}{*}{1} \\
\hline & 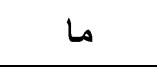 & & & & & $r \ldots$ & $\varepsilon \wedge$. & rr.. & $\%$ & & \\
\hline \multirow{2}{*}{ ir.. } & موافق لد & \multirow{2}{*}{$\cdots \varepsilon r$} & \multirow{2}{*}{ T.Y^. } & \multirow{2}{*}{.$\vee 1 \varepsilon$} & \multirow{2}{*}{1.91} & ir & ro & ir & $ت$ & \multirow{2}{*}{ له إيجابيات كثيرة في تحسين } & \multirow{2}{*}{ r } \\
\hline & ما & & & & & $r \varepsilon$. & $0 \ldots$ & หq.. & $\%$ & & \\
\hline \multirow{2}{*}{ r.. } & موافق لحد & \multirow{2}{*}{$\ldots v$. } & \multirow{2}{*}{ O.r. } & \multirow{2}{*}{$\cdot v \varepsilon r$} & \multirow{2}{*}{ Y. Y $\varepsilon$} & YI & r. & 9 & $ت$ & \multirow{2}{*}{ يمثل عبء إضافي على كاهل } & \multirow{2}{*}{$r$} \\
\hline & 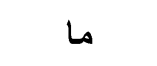 & & & & & $\varepsilon r .$. & $\varepsilon \ldots$ & $11 .$. & $\%$ & & \\
\hline \multirow{2}{*}{ o.. } & موافق لحد & \multirow{2}{*}{. rrr } & \multirow{2}{*}{ r.9r. } & \multirow{2}{*}{.$\vee \vee \vee \varepsilon$} & \multirow{2}{*}{ r.l^ } & $r$. & 19 & 11 & $ت$ & \multirow{2}{*}{ يتعارض ميع الجدول الزمني } & \multirow{2}{*}{$\varepsilon$} \\
\hline & L & & & & & $\varepsilon \ldots$ & r^.. & r... & $\%$ & & \\
\hline \multirow{2}{*}{ १.. } & موافق لحد & \multirow{2}{*}{.1 .7} & \multirow{2}{*}{$\varepsilon . \varepsilon \wedge$. } & \multirow{2}{*}{ 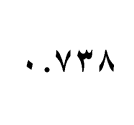 } & \multirow{2}{*}{ r.17 } & 11 & $r r$ & 1. & $ت$ & \multirow{2}{*}{ يـهتم بالثكل على حساب } & 0 \\
\hline & ما & & & & & r... & $\varepsilon \varepsilon \ldots$ & $r \cdot$. & $\%$ & & \\
\hline 1. & موافق لدد & * * & $17 \& \Lambda$. & 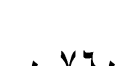 & $r \leqslant 4$ & $r$ & ir & $\wedge$ & $ت$ & يتطلب إعادة بناء المناهج & 7 \\
\hline 1. & ما & . & 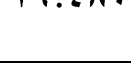 & . & 1.06 & $7 \cdot \ldots$ & $r \varepsilon$. & 17. & $\%$ & بطريقة مناسبة. & r \\
\hline & موافق لحد & & & & & $r$. & iv & ir & $ت$ & يحسن توظيف المقررات & \\
\hline$r$. & & 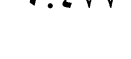 & 1.06 & (1) & 1.16 & $\varepsilon \ldots$ & $r \varepsilon$. & หч.. & $\%$ & الار اسية. & $r$ \\
\hline
\end{tabular}




\begin{tabular}{|c|c|c|c|c|c|c|c|c|c|c|c|}
\hline الرتبة & الموا(فقة & الالالة & قيمة & الانحراف & المسابي & تموافق & موافق إلى مد ما & غوافق & $ت$ & العبارة & الرقم \\
\hline \multirow{2}{*}{19.} & موافق لحد & \multirow{2}{*}{$\cdot r \cdot r$} & \multirow{2}{*}{ r.19. } & \multirow{2}{*}{.$\vee \vee 04$} & \multirow{2}{*}{1.17} & 11 & YI & 11 & $ت$ & \multirow{2}{*}{ يجعل أسرة المدرسة تعمل } & \multirow{2}{*}{$\Lambda$} \\
\hline & 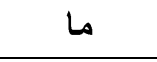 & & & & & rr.e & $\varepsilon r . \cdot$ & мч.. & $\%$ & & \\
\hline \multirow{2}{*}{$\varepsilon}$. & موافق لد & \multirow{2}{*}{$.11 \% 0$} & \multirow{2}{*}{$\varepsilon \ldots$} & \multirow{2}{*}{.$v \bullet 0$} & \multirow{2}{*}{ r.r } & $r \cdot$ & $r \cdot$ & 1. & $ت$ & \multirow{2}{*}{ تيفرض على المعلم ضرورة } & \multirow{2}{*}{9} \\
\hline & 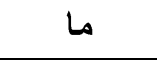 & & & & & $\varepsilon \cdots$ & $\varepsilon \cdots$ & $r \cdot$. & $\%$ & & \\
\hline \multirow{2}{*}{ IV.. } & موافق لحد & \multirow{2}{*}{$\cdot 7 \cdot v$} & \multirow{2}{*}{$1 \ldots$} & \multirow{2}{*}{.$\wedge r q$} & \multirow{2}{*}{1.9} & 10 & 10 & $r$. & $ت$ & \multirow{2}{*}{ يقلل من مشكلة الدروس الخصوصية. } & \multirow{2}{*}{$1 \cdot$} \\
\hline & ما & & & & & $r \ldots$ & $r \cdot . \cdot$ & $\varepsilon \cdots$ & $\%$ & & \\
\hline \multirow{2}{*}{ Ir.. } & موافق لحد & \multirow{2}{*}{$\cdots r \cdot$} & \multirow{2}{*}{$\vee . \wedge \varepsilon}$. & \multirow{2}{*}{. .799} & \multirow{2}{*}{ r.. } & ir & ry & ir & $ت$ & \multirow{2}{*}{ تيستخم فنيات بسيطة في } & \multirow{2}{*}{11} \\
\hline & ما & & & & & $r \varepsilon \ldots$ & or.. & $r \varepsilon \ldots$ & $\%$ & & \\
\hline \multirow{2}{*}{ YI.. } & موافق لحد & \multirow{2}{*}{$\cdots r \cdot$} & \multirow{2}{*}{$\vee . \wedge \varepsilon}$. & \multirow{2}{*}{. .799} & \multirow{2}{*}{1.1} & $\wedge$ & $r \varepsilon$ & 11 & $ت$ & \multirow{2}{*}{ يربط المدرسة بالمنزل } & \multirow{2}{*}{ ir } \\
\hline & ما & & & & & 17. & $\varepsilon \wedge$. & м... & $\%$ & & \\
\hline 9. & موافق لدد & $* * \ldots 7$ & $1, \mathrm{~m}_{\mathrm{T}}$ & . IVY & $r 1$ & $1 \varepsilon$ & $r v$ & 9 & $ت$ & يستخدم أساليب متعددة في & in \\
\hline$\cdots$ & ما & -. & 1. & - & 1.1 & r^.. & $0 \leqslant$. & $1 \wedge .$. & $\%$ & تقويم الطلاب. & r \\
\hline $1 \leqslant$ & موافق لحد & .19 & $y 94$. & .991 & 19 & 11 & r & ir & $ت$ & & 14 \\
\hline 18.0 & ما & $\cdots 17$ & 8.71. & $.17 n$ & 1.71 & r... & or.. & rq.. & $\%$ & يخس عدة & 18 \\
\hline $1 \mathrm{~V}$. & موافق لحد & $.71 \varepsilon$ & $y .7$. & $0,11 \leqslant$ & 19 & $1 \varepsilon$ & iv & 19 & $ت$ & يجب تعميمه على كل المراحل & 10 \\
\hline . & ما & . & . & . & 1. & r^.. & $r \varepsilon$. & r^.. & $\%$ & لأته يعد الطالب لسوق العمل. & 10 \\
\hline
\end{tabular}




\begin{tabular}{|c|c|c|c|c|c|c|c|c|c|c|c|}
\hline الرتبة & الموافقة & الدلالة & قيمة & الالمراف & المسابي & تموافق & موافق إلى مد ما & غوافق & $ت$ & العبارة & الرقم \\
\hline \multirow{2}{*}{$1 \wedge . \cdot$} & موافق لحد & \multirow{2}{*}{$.17 r$} & \multirow{2}{*}{ r. r. } & \multirow{2}{*}{ 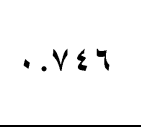 } & \multirow{2}{*}{1.11} & 11 & rr & iv & $ت$ & \multirow{2}{*}{ يرفع من جودة العملية } & \multirow{2}{*}{17} \\
\hline & L & & & & & rr.. & $\varepsilon \varepsilon \ldots$ & $r \varepsilon$. & $\%$ & & \\
\hline \multirow{2}{*}{$19 . \cdot$} & موافق لحد & \multirow{2}{*}{.rqr } & \multirow{2}{*}{ r.ฬ人. } & \multirow{2}{*}{$\cdot . \wedge \odot \vee$} & \multirow{2}{*}{1.19} & 10 & ir & rr & $ت$ & \multirow{2}{*}{ يكثف عن مواهب وقدرات } & \multirow{2}{*}{ iv } \\
\hline & 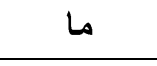 & & & & & $r \cdot . \cdot$ & r५.. & $\varepsilon \varepsilon \ldots$ & $\%$ & & \\
\hline \multirow{2}{*}{$10 .}$. & موافق لحد & \multirow{2}{*}{.$r v \theta$} & \multirow{2}{*}{1.97} & \multirow{2}{*}{. } & \multirow{2}{*}{$1.9 \varepsilon$} & ir & YI & 17 & $ت$ & \multirow{2}{*}{ يقلل من رهبة الامتحانات } & \multirow{2}{*}{11} \\
\hline & ما & & & & & r५.. & $\varepsilon r .$. & r... & $\%$ & & \\
\hline \multirow{2}{*}{$r \cdot . \cdot$} & موافق لحد & \multirow{2}{*}{. $.1 .7$} & \multirow{2}{*}{$\varepsilon . \leqslant \wedge$. } & \multirow{2}{*}{$\cdot V r \wedge$} & \multirow{2}{*}{$1 . \wedge \varepsilon$} & 1. & $r r$ & 11 & $ت$ & \multirow{2}{*}{ يعوق سير العملية التعليمية. } & \multirow{2}{*}{19} \\
\hline & ما & & & & & $r \cdot . \cdot$ & $\varepsilon \varepsilon \ldots$ & м... & $\%$ & & \\
\hline \multirow{2}{*}{ Ir.. } & موافق لحد & \multirow{2}{*}{$\cdots \wedge 9$} & \multirow{2}{*}{$\varepsilon . \wedge \varepsilon}$. & \multirow{2}{*}{$\because \vee \curlyvee \wedge$} & \multirow{2}{*}{ r.. } & ir & $r \varepsilon$ & ir & $ت$ & \multirow{2}{*}{ يهتم بالعمليات العقلية العليا } & \multirow{2}{*}{$r}$. \\
\hline & ما & & & & & r... & $\varepsilon \wedge$. & r... & $\%$ & & \\
\hline 14 & موافق لحد & $1, \Delta \varepsilon$ & $<94$ & - YrY & 199 & ir & $r \varepsilon$ & $1 \varepsilon$ & $ت$ & يزيد من اعتماد الطلاب على & $r_{1}$ \\
\hline . & ما & (9) & an & (2) & 1.0 & $r \varepsilon \ldots$ & $\varepsilon \wedge$. & r^.. & $\%$ & المعلم. & 1 \\
\hline $1 \leqslant$ & موافق لحد & * * & r 1 rA. & 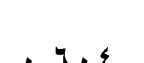 & 19 & $\wedge$ & rr & 1. & $ت$ & يزيد من تعاون الطلاب مع & ty \\
\hline . & ما & -.. & 1 & . & $1 . .1$ & 17. & $7 \varepsilon$. & $r \cdot . \cdot$ & $\%$ & بعضهم البعض. & r \\
\hline $1 \%$ & موافق لحد & $.17 r$ & r. & $. \quad y \leqslant Y$ & 191 & หч.. & $\varepsilon 7$. & r^.. & $ت$ & يجعل الطالب أكثر حرية في & r \\
\hline (. & ما & 011 & $1 . .6$ & 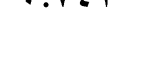 & $1.0 \mathrm{n}$ & หч.. & $\varepsilon ५$. & r^.. & $\%$ & أداء مايحب. & r \\
\hline
\end{tabular}




\begin{tabular}{|c|c|c|c|c|c|c|c|c|c|c|c|}
\hline الرتبة & الموافقة & الالالة & قيمة & الالحراف & المسابي & تموافق & موافق إلى & غو غير & $ت$ & 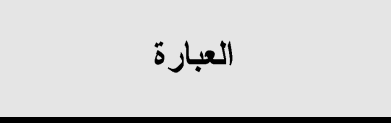 & 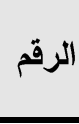 \\
\hline \multirow{2}{*}{$1 \cdots$} & موافق لحد & \multirow{2}{*}{$* * \ldots r$} & \multirow{2}{*}{11.71.} & \multirow{2}{*}{. .741} & \multirow{2}{*}{ r... $\varepsilon$} & ir & $r \wedge$ & 1. & $ت$ & \multirow{2}{*}{ (يجتعد على الطالب متعلما ذاتيا } & \multirow{2}{*}{$r \leqslant$} \\
\hline & L & & & & & r£.. & 07. & $r \cdot$. & $\%$ & & \\
\hline \multirow{2}{*}{$11 .}$. & موافق لدـ & \multirow{2}{*}{$* * \ldots \wedge$} & \multirow{2}{*}{$9.7 \varepsilon}$. & \multirow{2}{*}{. $.7 \wedge \varepsilon$} & \multirow{2}{*}{$r . . r$} & ir & $r v$ & 11 & $ت$ & \multirow{2}{*}{ يكثف باستمرار عن مدى } & \multirow{2}{*}{ ro } \\
\hline & ما & & & & & $r \varepsilon \ldots$ & 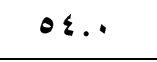 & r... & $\%$ & & \\
\hline \multirow{2}{*}{$10 .}$. & موافق لحد & \multirow{2}{*}{$* * \ldots v$} & \multirow{2}{*}{$9 . \wedge \wedge$. } & \multirow{2}{*}{..$T \wedge r$} & \multirow{2}{*}{$1.9 \varepsilon$} & $1 \cdot$ & rV & ir & $ت$ & \multirow{2}{*}{ يجعل الطالب أكثر ارتباطا } & \multirow{2}{*}{ ry } \\
\hline & ما & & & & & $r \cdot . \cdot$ & $\Delta \varepsilon \ldots$ & ห५.. & $\%$ & & \\
\hline \multirow{2}{*}{ १^.. } & موافق لحد & \multirow{2}{*}{$\cdots 1 r$} & \multirow{2}{*}{$\Lambda .9 r}$. & \multirow{2}{*}{. .719} & \multirow{2}{*}{$1 . \wedge 1$} & 9 & r & 10 & $ت$ & \multirow{2}{*}{ يجعل عملية التقويم أكثر } & \multirow{2}{*}{$r v$} \\
\hline & ما & & & & & $1 \wedge$. & or.. & $\mu \cdot$ & $\%$ & & \\
\hline \multirow{2}{*}{19.} & موافق لحد & \multirow{2}{*}{$\ldots v \cdot$} & \multirow{2}{*}{ O.r. } & \multirow{2}{*}{.$V Y r$} & \multirow{2}{*}{$1.9 r$} & 11 & $r \varepsilon$ & 10 & $ت$ & \multirow{2}{*}{ ليكون دافعا باستمر إنجاز الطالب للتحسن } & \multirow{2}{*}{$r \wedge$} \\
\hline & ما & & & & & rr.. & $\varepsilon \wedge$. & $\mu \cdot$ & $\%$ & & \\
\hline 11 & موافق لحد & $19 r$ & ז & 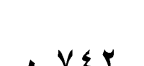 & $r$ & $1 \varepsilon$ & $r r$ & ir & $ت$ & يجعل الطالب أكثر فاعلية & $r a$ \\
\hline 年 & ما & 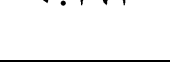 & 1.00 & 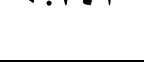 & 1.. & r^.. & 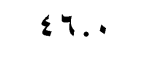 & r५.. & $\%$ & داخل الفصل الدراسي. & 1 \\
\hline 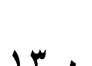 & موافق لحد & 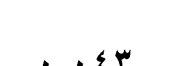 & $y \mathrm{rA}$ & $0 \times 14$ & 191 & ir & ro & ir & $ت$ & يدفع الطالب لممارسة أنشطة & $\omega$ \\
\hline 11. & ما & $\cdots 21$ & 1.110 & 0.012 & $1.7 n$ & $r \varepsilon$. & 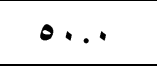 & rq.. & $\%$ & مختلفة داخل المدرسة. & 1. \\
\hline ir. & موافق لحد & $r_{r}$ & $y \wedge \varepsilon$. & .799 & r & ir & rq & ir & $ت$ & يحسن من مستوى الأداء & w \\
\hline 年 & ما & . & r.ten & . & 1. & $r \varepsilon \ldots$ & or.. & $r \varepsilon$. & $\%$ & داخل المدرسة. & 1 \\
\hline
\end{tabular}




\begin{tabular}{|c|c|c|c|c|c|c|c|c|c|c|c|}
\hline الرتبة & الموافقة & الالالة & قيمة & الالحراف & المسابي & تموافق & موافق إلى & غو غير & $ت$ & العبارة & الرقم \\
\hline \multirow{2}{*}{ IV.. } & \multirow{2}{*}{ موافق لحد } & \multirow{2}{*}{. $.11 \%$} & \multirow{2}{*}{$\varepsilon . r q}$. & \multirow{2}{*}{$\cdot v r_{0}$} & \multirow{2}{*}{1.9} & 11 & $r r$ & 17 & $ت$ & \multirow{2}{*}{ أنسب طريقة للتقويم في ظل } & \multirow{2}{*}{ rr } \\
\hline & & & & & & rr.e & 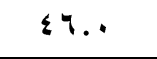 & rr.. & $\%$ & & \\
\hline \multirow{2}{*}{$10 .}$. & \multirow{2}{*}{ موافق لحد } & \multirow{2}{*}{.$r v \theta$} & \multirow{2}{*}{1.97.} & \multirow{2}{*}{..$\vee 44$} & \multirow{2}{*}{$1.9 \varepsilon$} & rч.. & $\varepsilon r .$. & r... & $ت$ & \multirow{2}{*}{ يقدم تغذية راجعة مناسبة } & \multirow{2}{*}{ rr } \\
\hline & & & & & & r... & $\varepsilon r .$. & r... & $\%$ & & \\
\hline \multirow{2}{*}{$1 \varepsilon \ldots$} & \multirow{2}{*}{ موافق لحد } & \multirow{2}{*}{$\cdots \wedge \varepsilon$} & \multirow{2}{*}{$\varepsilon .97$} & \multirow{2}{*}{. VYV } & \multirow{2}{*}{1.97} & ir & $r \varepsilon$ & $1 \varepsilon$ & $ت$ & \multirow{2}{*}{ يزيد من إقبال الطالب على الدراسة. } & \multirow{2}{*}{$r \varepsilon$} \\
\hline & & & & & & $r \varepsilon \ldots$ & $\varepsilon \wedge$. & r^.. & $\%$ & & \\
\hline \multirow{2}{*}{ 9.. } & \multirow{2}{*}{ موافق لحد } & \multirow{2}{*}{$* \ldots \ldots 1$} & \multirow{2}{*}{$1 \varepsilon . \varepsilon \varepsilon}$. & \multirow{2}{*}{$.9 \leqslant 4$} & \multirow{2}{*}{ r.l } & ir & rq & $\wedge$ & $ت$ & \multirow{2}{*}{ يهتم بجوانب شخصية الطالب } & \multirow{2}{*}{ ro } \\
\hline & & & & & & r... & $\bullet \wedge$. & 17. & $\%$ & & \\
\hline \multirow{2}{*}{ IV.. } & \multirow{2}{*}{ موافق لحد } & \multirow{2}{*}{$\cdots+$} & $y, \ldots$ & $-x, y$ & 19 & 1. & ro & 10 & $ت$ & يخلق تنافس محمود بين & w \\
\hline & & & r. & r & 1.9 & $r \cdot$. & $0 \ldots$ & $\mu \cdot$. & $\%$ & الطلاب. & 1 \\
\hline 14 & موافق لحد & G $r$ & $r$. & Q yos & 19 & ir & $r r$ & 10 & $ت$ & يستثر طاقات الطلاب & wy \\
\hline . & ما & r & $1.0 \mathrm{n}$ & 90 & 1.1 & r... & $\varepsilon \varepsilon \ldots$ & $\mu \cdot$. & $\%$ & بطريقة جيدة. & r \\
\hline . & موافق لحد & 19 & $y 97$ & 991 & $r$ & ir & r & 11 & $ت$ & يوفر قرا من المتابعة لأداء & $\mathrm{m}$ \\
\hline$\cdots$ & ما & 0.17 & 8.710 & ת & 1.78 & หч.. & or.. & r... & $\%$ & المعلمين. & $1 n$ \\
\hline 10. & موافق لحد & - myo & 199. & .874 & 198 & ir & Yl & 17 & $ت$ & يطور من أسلوب تفكير & $\mathrm{mg}$ \\
\hline 0 & ما & 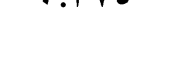 & 1.0. & 9.6 & 1.16 & หч.. & $\varepsilon r .$. & rr.. & $\%$ & الطلاب. & 1. \\
\hline
\end{tabular}




\begin{tabular}{|c|c|c|c|c|c|c|c|c|c|c|c|}
\hline الرتبة & المورجة & الالالة & قيمة & الالمحراف & المتوسط & موافق & موافق إلى & غوافق & $ت$ & 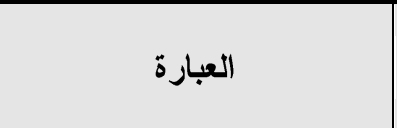 & الرقم \\
\hline \multirow{2}{*}{$11 .}$. & \multirow{2}{*}{ موافق لحد } & \multirow{2}{*}{$\cdots \leqslant r$} & \multirow{2}{*}{ Y.Y^. } & \multirow{2}{*}{$\because V 1 \leq$} & \multirow{2}{*}{$r . . r$} & ir & ro & ir & $ت$ & \multirow{2}{*}{ نواحي القصور في أداء الطالب. } & \multirow{2}{*}{$\varepsilon$. } \\
\hline & & & & & & r... & $\bullet \cdot$. & $r \varepsilon .$. & $\%$ & & \\
\hline \multirow{2}{*}{$11 .}$. & \multirow{2}{*}{ موافق لحد } & \multirow{2}{*}{$\cdots \varepsilon r$} & \multirow{2}{*}{ ૫.૫^. } & \multirow{2}{*}{.$\vee V \backslash \varepsilon$} & \multirow{2}{*}{$r . . r$} & ir & ro & ir & $ت$ & \multirow{2}{*}{ يجعل الطالب متعلما نشطا } & \multirow{2}{*}{ \&1 } \\
\hline & & & & & & หч.. & $\bullet .$. & $r \varepsilon .$. & $\%$ & & \\
\hline \multirow{2}{*}{19.} & \multirow{2}{*}{ موافق لحد } & \multirow{2}{*}{$* * \ldots v$} & \multirow{2}{*}{ O.ru. } & \multirow{2}{*}{$\cdot V r r$} & \multirow{2}{*}{$1.9 r$} & 11 & $r \varepsilon$ & 10 & $ت$ & \multirow{2}{*}{ يدفع الطالب للبحث عن المعلومات من مصادر متعددة } & \multirow{2}{*}{$\varepsilon r$} \\
\hline & & & & & & rr.. & $\varepsilon \wedge$. & $r \ldots$ & $\%$ & & \\
\hline \multirow{2}{*}{$10 .}$. & \multirow{2}{*}{ موافق لحد } & \multirow{2}{*}{$* * \ldots v$} & \multirow{2}{*}{$9 . \wedge \wedge$. } & \multirow{2}{*}{..$r \wedge r$} & \multirow{2}{*}{$1.9 \varepsilon$} & 1. & $r v$ & ir & $ت$ & \multirow{2}{*}{ فراعى ما بين الطالب من فروق فرية. } & \multirow{2}{*}{$\varepsilon r$} \\
\hline & & & & & & $r \cdot . \cdot$ & 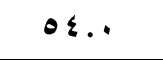 & rq.. & $\%$ & & \\
\hline \multirow{2}{*}{ ^.. } & \multirow{2}{*}{ موافق لحد } & \multirow{2}{*}{. $.0 V_{1}$} & \multirow{2}{*}{$1.1 \%$} & $\Delta \mathrm{r}<$ & $r i r$ & $r \cdot$ & 19 & $1 \varepsilon$ & $ت$ & يقبد حرية المعلم في اختيار & 4 \\
\hline & & & & 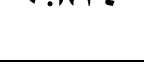 & 1.0 & $\varepsilon \cdots$ & Mr.. & r^.. & $\%$ & | وسيلة التقويم المناسبة للطلاب & \\
\hline$\omega$ & موافق لحد & 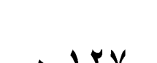 & 4,4 & $y=r$ & $r \quad r r$ & ri & 19 & 1. & $ت$ & يجب إلغاؤه لأنه لا يختلف & 40 \\
\hline 1. & ما & ת & 的 & (.) & 1.0 & $\varepsilon r .$. & r^.. & $r \ldots$ & $\%$ & عن طرق التقويم العادية. & \\
\hline & لدو افق ما & & & . . $\varepsilon r r$ & r... & & & & لألداء & & \\
\hline
\end{tabular}




\section{|تضع من نتائج الجدول (7):}

أنّ جميع فقرات المقياس قد حازت على درجة مو افق لحدٍ ما من التقدير •

وقد جاءت بالمرتبة الأولى الفقرة رقم (T) و التي تتص على: " بتطلب إعادة بناء

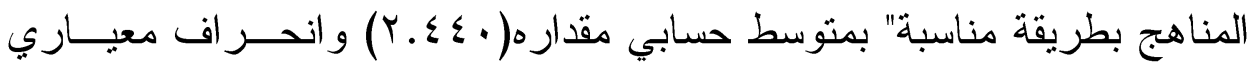
مقداره ( • VT. ·). وقد يكون السبب في حصول هذه الفقرة على المرتبة الأولـى عند معلمي المرحلة المتوسطة، كون عملية انتقال الطالب من المرحلة الابتدائية إلى المرحلة المتوسطة تحتاج إلى ضرورة إعادة النظر جيدًا بالمنــاهج، حتــى تتلاءم مع مر احل النمو المعرفي لدى الطلبة المختلفة، وبالتالي فإن تبني مشروع التقويم الثامل يمهد الطريق إلى عمل إعادة شاملة للمناهج في مرحلــة التعلــيم المتوسط على وجه الخصوص. وجاءت بالمرتبة الثانية الفقرة رقم(r) و التي تتص على: "يمثـل عـبــ

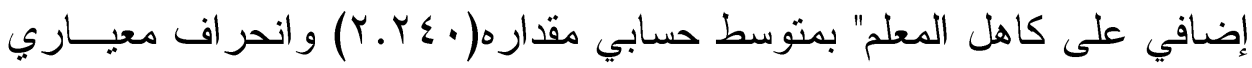

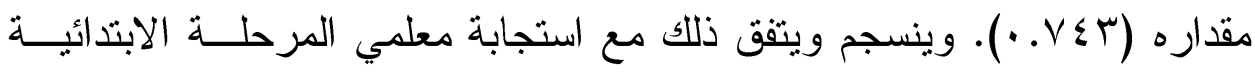
(المرتبة الأولى)، فهناك العديد من الأعباء على المعلمين و التي تختلف باختلاف المرحلة الدراسية، وبالتالي فإنّ أي جهذ آخر سيشكل عبء إضافي على المعلم، خصوصًا عند تبني سياسة تقويم جديدة لتقويم الطلبة. كما أن التحول من شـيء مألوف الى آخر جديد غالبًا ما يقابل بالرفض ويأخذ وقتًا طويلًا حتى يعتاد عليه الأفر اد.

\section{النتائج الخاصة بمعلمي المرحلة الثانوية:}

تم حساب تكر ار ات مدى مو افقة معلمي المرحلة الثانوية على عبار ات المقيــاس، وكذلك النسبة المئوية، كما حسبت قيمة لحسن المطابقة

لكل عبارة من عبار ات مقياس اتجاهات المعلمين في المرحلة الثانوية (r N معلم) نحو تطبيق التقـويم الثـــامل كمـــا هـــو موضــح فــي الجـدول رقـم (V) 


\begin{tabular}{|c|c|c|c|c|c|c|c|c|c|c|c|}
\hline ل تجباه & مقياس & على فقر & م & ميارية & نحر افات & لمابة و & شويم الش الث & والمة & & (V) التكر ارات، والتسب & جدو \\
\hline الرتبة & الموافقة & الدلاية & قيمة & الإنحر افتياري & المتوسط & موافق & مو افق & غير & $ت$ & العبارة & الرقم \\
\hline \multirow{2}{*}{$1 \cdots$} & موافق & \multirow{2}{*}{$* * \ldots$} & \multirow{2}{*}{$10.71 \%$} & \multirow{2}{*}{. $.7 \wedge$} & \multirow{2}{*}{1.170} & $1 \varepsilon$ & $\varepsilon r$ & ro & $ت$ & \multirow{2}{*}{ يعالج عيوب طرق التقويم } & \multirow{2}{*}{1} \\
\hline & ل ل & & & & & 18.1 & or.s & $r . .0$ & $\%$ & & \\
\hline \multirow{2}{*}{$9 .}$. & موافق & \multirow[t]{2}{*}{$* * \ldots 1$} & \multirow{2}{*}{$1 \varepsilon .901$} & \multirow{2}{*}{.710} & \multirow{2}{*}{1.19} & 10 & $\varepsilon r$ & $r \varepsilon$ & $ت$ & \multirow{2}{*}{ له إيجابيات كثيرة في تحسين } & \multirow{2}{*}{$r$} \\
\hline & ل لحد ما & & & & & I^.r & or.z & rq.r & $\%$ & & \\
\hline \multirow{2}{*}{17.} & موافق & \multirow{2}{*}{$\cdots+\Lambda$} & \multirow{2}{*}{ 7.0rV } & \multirow{2}{*}{. .117} & \multirow{2}{*}{ I.VA. } & $r \cdot$ & $r \varepsilon$ & rA & $ت$ & \multirow{2}{*}{ يمثل عبء إضافي على كاهل } & \multirow{2}{*}{$r$} \\
\hline & ل لحد ما & & & & & $r \varepsilon . \varepsilon$ & rq.r & $\varepsilon 7 . r$ & $\%$ & & \\
\hline \multirow{2}{*}{ ^.. } & موافق & \multirow{2}{*}{$.1 r v$} & \multirow{2}{*}{$\varepsilon .1 r r$} & \multirow{2}{*}{.004} & \multirow{2}{*}{1.918} & $r$. & ro & rv & $ت$ & \multirow{2}{*}{ يتعارض مع الجدول الزمني } & \multirow{2}{*}{$\varepsilon$} \\
\hline & ل لحد ما & & & & & $r \varepsilon . \varepsilon$ & $\varepsilon r . V$ & r.q. & $\%$ & & \\
\hline \multirow{2}{*}{ r.. } & موافق & \multirow{2}{*}{. } & \multirow{2}{*}{ Y.rY. } & \multirow{2}{*}{$\cdots \vee \wedge 0$} & \multirow{2}{*}{$r .1 .9$} & $r$. & m & Y & $ت$ & \multirow{2}{*}{ يـهتم بالشكل على حساب } & \multirow{2}{*}{ • } \\
\hline & ل لحد ما & & & & & r.. & rv.ı & ro. & $\%$ & & \\
\hline 1. & موافق & $* * \ldots 1$ & 15041 & & Y r IV & rA & rr & ir & $ت$ & يتطلب إعادة بناء المناهج & 7 \\
\hline . & ل لحد ما & & 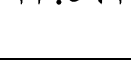 & re r & r r & $\varepsilon \neg . r$ & rq.. & $1 \varepsilon .7$ & $\%$ & بطريقة مناسبة. & 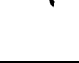 \\
\hline$\varepsilon$ & موافق & 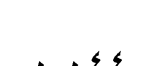 & $y<\varepsilon$ & & $Y$ & $r r$ & rᄉ & $r r$ & $ت$ & يحسن توظيف المقررات & $y$ \\
\hline$\cdots$ & لحد ما & 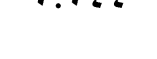 & 1.16 & 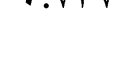 & 1. & r..А & $\varepsilon 7 . r$ & r..A & $\%$ & الار اسية. & $r$ \\
\hline
\end{tabular}




\begin{tabular}{|c|c|c|c|c|c|c|c|c|c|c|c|}
\hline الرتبة & الموافقة & الدلالة & قيمة & الإنحراف & المتوسط & تموافق & إلى حوافق ما & مو غير & $ت$ & العبارة & الرق \\
\hline \multirow{2}{*}{ V.. } & موافق & \multirow{2}{*}{$\ldots r r$} & \multirow{2}{*}{$7.9 \cdot r$} & \multirow{2}{*}{.$v r r$} & \multirow{2}{*}{$1.9 r 7$} & 19 & rᄉ & ro & $ت$ & \multirow{2}{*}{ يجعل أسرة المدرسة تعمل في } & \multirow{2}{*}{$\wedge$} \\
\hline & لحد ما & & & & & rr.r & $\leq 4 . r$ & $r \cdot .0$ & $\%$ & & \\
\hline \multirow{2}{*}{$0 . \cdot$} & مو افق & \multirow{2}{*}{$.7 r v$} & \multirow{2}{*}{ r.q. } & \multirow{2}{*}{.var } & \multirow{2}{*}{1.994} & $r \varepsilon$ & $\mu_{1}$ & $r v$ & $ت$ & \multirow{2}{*}{ تصرض على المعلم ضرورة } & \multirow{2}{*}{9} \\
\hline & ل ل ل & & & & & rq.r & rV.A & rr.q & $\%$ & & \\
\hline \multirow{2}{*}{ Ir.. } & موافق & \multirow{2}{*}{$-.1 \leqslant V$} & \multirow{2}{*}{ r.Arq } & \multirow{2}{*}{$\because \vee V V$} & \multirow{2}{*}{$1 . \wedge \leq 1$} & 19 & $\mu_{1}$ & rr & 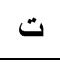 & \multirow{2}{*}{ يقلل من مثكلة الاروس } & \multirow{2}{*}{$1 \cdot$} \\
\hline & ل لحد ما & & & & & rr.r & rV.A & rq.. & $\%$ & & \\
\hline \multirow{2}{*}{ Ir.. } & موافق & \multirow{2}{*}{$\cdots 17$} & \multirow{2}{*}{ A.r. } & \multirow{2}{*}{$\because$ VrA } & \multirow{2}{*}{$1 . \wedge \leq 1$} & 17 & rv & rq & 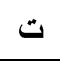 & \multirow{2}{*}{ يستخدم فنيات بسيطة في } & \multirow{2}{*}{11} \\
\hline & لعد ما & & & & & 19.0 & $\leq 0.1$ & ro.z & $\%$ & & \\
\hline \multirow{2}{*}{$1 \wedge}$. & موافق & \multirow{2}{*}{$* * \ldots r$} & \multirow{2}{*}{$11 . \varepsilon+9$} & \multirow{2}{*}{$\cdot v \mid r$} & \multirow{2}{*}{1.204} & ir & $m$ & m & $\ddot{H}$ & \multirow{2}{*}{ يربط المدرسة بالمنزل } & \multirow{2}{*}{ ir } \\
\hline & ل لحد ما & & & & & 10.9 & $\varepsilon r .9$ & $\varepsilon \ldots r$ & $\%$ & & \\
\hline 14. & موافق & $1,1<$ & $\Lambda 01 r$ & $x \leqslant 4$ & 1 yo & 10 & rr & ro & $ت$ & يستخدم أساليب متعددة في & w \\
\hline 等 & لحد ما & 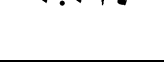 & r. & 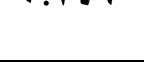 & 1.02 & IA.r & rq.. & $\varepsilon r . V$ & $\%$ & تقويم الطلاب & r \\
\hline r). & موافق & ** & $11 \gamma^{\prime} r r$ & VYA & $1 \times$ & ir & rr & rv & 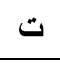 & & 4 \\
\hline 1. & ل لحد ما & . & 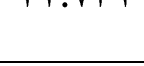 & ? & 1.0 .8 & 10.9 & rq.. & $\varepsilon 0.1$ & $\%$ & ب بقمتم. & 16 \\
\hline r. & موافق & $* * \ldots$ & $1<47$ & . $v a t$ & $19 y$ & 17 & $r$ & $\varepsilon r$ & $ت$ & يجب تعميمه على كل المراحل & 0 \\
\hline (. & ل لحد ما & .. & 10.0 & י & 1.04 & 19.0 & r^.. & or.s & $\%$ & لأنه يعد الطالب لسوق العمل. & re \\
\hline
\end{tabular}




\begin{tabular}{|c|c|c|c|c|c|c|c|c|c|c|c|}
\hline الرتبة & المو (فقة & الدلاية & قيمة & الالمعراف & المستوسط & تموافق & موافق & غوافت & $ت$ & العبارة & 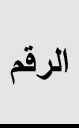 \\
\hline \multirow{2}{*}{$1 \cdots$} & موافق & \multirow{2}{*}{$.1 T V$} & \multirow{2}{*}{ r.9V4 } & \multirow{2}{*}{$\cdots \vee 70$} & \multirow{2}{*}{1.190} & 19 & $r r$ & $r$. & $ت$ & \multirow{2}{*}{ يرفع من جودة العملية } & \multirow{2}{*}{17} \\
\hline & لعد ما & & & & & rr.r & $\varepsilon \cdot r$ & r.. & $\%$ & & \\
\hline \multirow{2}{*}{$r \varepsilon \ldots$} & 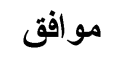 & \multirow{2}{*}{$* * \ldots$} & \multirow{2}{*}{$10.71 \mathrm{r}$} & \multirow{2}{*}{$\cdots \vee \diamond q$} & \multirow{2}{*}{$1.7 \leq 7$} & $1 \varepsilon$ & ro & $\varepsilon r$ & $ت$ & \multirow{2}{*}{ يكثف عن مواهب وقدرات } & \multirow{2}{*}{ iv } \\
\hline & ل لعد ما & & & & & $1 v .1$ & $r \cdot .0$ & Or.z & $\%$ & & \\
\hline \multirow{2}{*}{$9 .}$. & 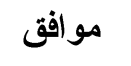 & \multirow{2}{*}{$\because \leqslant 11$} & \multirow{2}{*}{$1 . \vee \wedge$. } & \multirow{2}{*}{$\cdot . \wedge r 1$} & \multirow{2}{*}{$1 . \wedge 9$} & $r \leq$ & ro & rr & $ت$ & \multirow{2}{*}{ يقلل من رهبة الامتحانات } & \multirow{2}{*}{11} \\
\hline & ل لعد ما & & & & & rq.r & $r \cdot .0$ & $\varepsilon \cdot r$ & $\%$ & & \\
\hline \multirow{2}{*}{7.} & 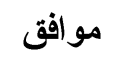 & \multirow{2}{*}{$\cdots 11$} & \multirow{2}{*}{$9 . .91$} & \multirow{2}{*}{$\cdots \vee 11$} & \multirow{2}{*}{1.901} & 19 & $\varepsilon$. & $r r$ & 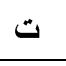 & \multirow{2}{*}{ يعوق سير العملية التعليمية } & \multirow{2}{*}{19} \\
\hline & ل لعد ما & & & & & rr.r & $\varepsilon \wedge . \wedge$ & r^.. & $\%$ & & \\
\hline \multirow{2}{*}{$r \ldots$} & موافق & \multirow{2}{*}{$* * \ldots 1$} & \multirow{2}{*}{14.190} & \multirow{2}{*}{. .799} & \multirow{2}{*}{$1 . v \leq r$} & ir & rV & rr & 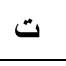 & \multirow{2}{*}{ يهتم بالعمليات العقلية العليا } & \multirow{2}{*}{$r}$. \\
\hline & 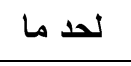 & & & & & $1 \varepsilon .7$ & $\varepsilon 0.1$ & $\varepsilon . . r$ & $\%$ & & \\
\hline 10 & 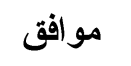 & $0.1<$ & $\Lambda 01 Y$ & Q VWr & 1 var & 10 & ro & rr & $ت$ & يزيد من اعتماد الطلاب على & 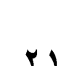 \\
\hline 年 & 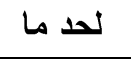 & 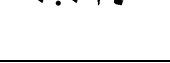 & r & 年 & י זי & $1 \wedge . r$ & $\varepsilon r . V$ & rq.. & $\%$ & المعلم. & $M$ \\
\hline IV & موافق & $* *$ & $1 \& \quad V \pi$ & 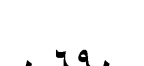 & $1 \mathrm{v} 4 \mathrm{~A}$ & ir & rq & r l & $\uplus$ & يزيد من تعاون الطلاب مع & $r \mathbf{r}$ \\
\hline 年 & ل لعد ما & -.. & 1 & . & $1.0 \mathrm{n}$ & $1 \varepsilon .7$ & $\varepsilon V .7$ & $r \vee . \wedge$ & $\%$ & بعضهم البعض & r \\
\hline $1 \leqslant$ & موافق & $* * \ldots 1$ & $1 \mu \leqslant \Delta \Lambda$ & $.79 r$ & $1.1 . \varepsilon$ & ir & $\varepsilon$. & rq & 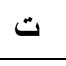 & يجعل الطالب أكثر حرية في & r \\
\hline 16 & ل لحد ما & - & 2. & r & 1.040 & 10.9 & $\varepsilon \wedge . \wedge$ & ro.s & $\%$ & أداء ما يحب. & 1 \\
\hline
\end{tabular}




\begin{tabular}{|c|c|c|c|c|c|c|c|c|c|c|c|}
\hline الرتبة & درجة المو افقة & الدلالة & قيمة & الآمراف & المتوسط & تموافق & مو افق & غير & $ت$ & العبارة & الرقم \\
\hline \multirow{2}{*}{ r... } & موافق & \multirow{2}{*}{$* * \ldots r$} & \multirow{2}{*}{$11 . \mathrm{VHr}$} & \multirow{2}{*}{.$\vee r \wedge$} & \multirow{2}{*}{$I . v \cdot v$} & ir & rr & $r v$ & $ت$ & \multirow{2}{*}{ يجعل الطالب منعلما ذاتيا (يعتمد } & \multirow{2}{*}{$r \varepsilon$} \\
\hline & ل لحد ما & & & & & 10.9 & rq.. & $\leq 0.1$ & $\%$ & & \\
\hline \multirow{2}{*}{ Ir.. } & 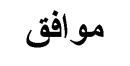 & \multirow{2}{*}{$. .1 \leq V$} & \multirow{2}{*}{ r.Arq } & \multirow{2}{*}{.$\vee \vee V$} & \multirow{2}{*}{$1 . \wedge \leq 1$} & 19 & r & rr & $ت$ & \multirow{2}{*}{ يكثف باستمرار عن مدى مستوى الطالب } & \multirow{2}{*}{ ro } \\
\hline & ل لحد ما & & & & & rr.r & rV.A & rq.. & $\%$ & & \\
\hline \multirow{2}{*}{10.} & موافق & \multirow{2}{*}{$* \ldots .0$} & \multirow{2}{*}{$1 \cdot . \leqslant 10$} & \multirow{2}{*}{$\cdots \times 10$} & \multirow{2}{*}{ l.var } & $1 \varepsilon$ & $r v$ & r & 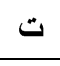 & \multirow{2}{*}{ يجعل الطالب أكثر ارتباطا } & \multirow{2}{*}{ rq } \\
\hline & 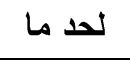 & & & & & $1 v .1$ & $\varepsilon 0.1$ & rv.^ & $\%$ & & \\
\hline \multirow{2}{*}{11.} & موافق & \multirow{2}{*}{$* \ldots . r$} & \multirow{2}{*}{11.249} & \multirow{2}{*}{$\cdot V \cdot \varepsilon$} & \multirow{2}{*}{ 1.nor } & 10 & $\varepsilon$. & rV & $ت$ & \multirow{2}{*}{ يجعل عملية التقويم أكثر } & \multirow{2}{*}{ rV } \\
\hline & لحد ما & & & & & I^.r & $\varepsilon \wedge . \wedge$ & rr.q & $\%$ & & \\
\hline \multirow{2}{*}{$9 .}$. & موافق & \multirow{2}{*}{. .191} & \multirow{2}{*}{$r . r \leq \varepsilon$} & \multirow{2}{*}{.879} & \multirow{2}{*}{1.19} & $r \cdot$ & $r r$ & rq & $ت$ & \multirow{2}{*}{ ليكون دافعا باستمر ار للتحساز الطالب } & \multirow{2}{*}{$r \wedge$} \\
\hline & ل لحد ما & & & & & $r \varepsilon . \varepsilon$ & $\varepsilon . . r$ & Ho.乏 & $\%$ & & \\
\hline 10. & موافق &., $1 \leqslant$ & $1.01 Y$ & Q V & l var & 10 & ro & rr & $ت$ & يجعل الطالب أكثر فاعلية & ra \\
\hline . & لحد ما & 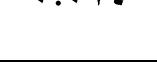 & r... & r & ז & $1 \wedge . r$ & $\varepsilon r . V$ & rq.. & $\%$ & داخل الفصل الدراسي. & 1 \\
\hline 19 & 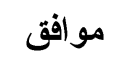 & $* *$ & 15190 & 999 & $1 \quad x<9$ & ir & rv & $r r$ & 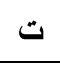 & يدفع الطالب لممارسة أنشطة & D. \\
\hline . & ل لحد ما & -. & 19. & . & 1.06 & $1 \varepsilon .7$ & $\varepsilon 0.1$ & $\varepsilon \ldots r$ & $\%$ & مختلفة داخل المدرسة. & 1 \\
\hline A. & 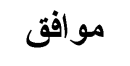 & - I ry & $\&$ Irr & - y० & 1918 & $r \cdot$ & ro & rv & $ت$ & يحسن من مستوى الأداء & $w_{1}$ \\
\hline$\ldots$ & لحد ما & 政 & 1 & $\because .80$ & 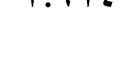 & $r \leq . \varepsilon$ & $\varepsilon r . V$ & rr.q & $\%$ & داخل المدرسة. & 1 \\
\hline
\end{tabular}




\begin{tabular}{|c|c|c|c|c|c|c|c|c|c|c|c|}
\hline الرتبة & الموجة افقة & الدلاية & قيمة & الالمعراف & المستوسط & تموافق & موافق & غيز & $ت$ & العبارة & الرق \\
\hline \multirow{2}{*}{$1 \% .}$. & موافق & \multirow{2}{*}{..or } & \multirow{2}{*}{$\bullet . \wedge \vee \wedge$} & \multirow{2}{*}{$\because v \Delta 0$} & \multirow{2}{*}{$1.11 \mathrm{~V}$} & IV & $r r$ & rr & $ت$ & \multirow{2}{*}{ أنسب طريقة للتقويم في ظل } & \multirow{2}{*}{ rr } \\
\hline & لعد ما & & & & & $r \cdot . r$ & $\varepsilon \cdot r$ & rq.. & $\%$ & & \\
\hline \multirow{2}{*}{$10 \ldots$} & 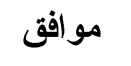 & \multirow{2}{*}{$\cdot .71$} & \multirow{2}{*}{$0.0 \wedge 0$} & \multirow{2}{*}{ 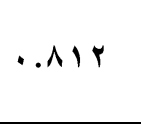 } & \multirow{2}{*}{$1 . v 9 r$} & $r \cdot$ & ro & $r v$ & $ت$ & \multirow{2}{*}{ يقدم تغذية راجعة مناسبة عن } & \multirow{2}{*}{$r r$} \\
\hline & لعد ما & & & & & $r \leq . \varepsilon$ & $r . .0$ & $\varepsilon 0.1$ & $\%$ & & \\
\hline \multirow{2}{*}{17.} & 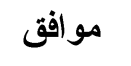 & \multirow{2}{*}{$\cdots r \wedge$} & \multirow{2}{*}{ V.I rr } & \multirow{2}{*}{$\cdot v \otimes r$} & \multirow{2}{*}{ I.VA. } & 17 & rr & $r \varepsilon$ & $\uplus$ & \multirow{2}{*}{ يزيد من إقبال الطالب } & \multirow{2}{*}{$r \varepsilon$} \\
\hline & 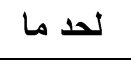 & & & & & $1 \varepsilon$ & $r r$ & ro & $\%$ & & \\
\hline \multirow{2}{*}{$r \cdot}$. & موافق & \multirow{2}{*}{$* * \ldots \vee V$} & \multirow{2}{*}{$9 . \wedge$ Y } & \multirow{2}{*}{. Vrr } & \multirow{2}{*}{$1 . v \leq r$} & $1 \varepsilon$ & $r r$ & ro & $ت$ & \multirow{2}{*}{ يرتم بجوانب شخصية الطالب } & \multirow{2}{*}{ ro } \\
\hline & ل ل لد ما & & & & & $1 v .1$ & $\varepsilon \cdot r$ & $\varepsilon r \cdot V$ & $\%$ & & \\
\hline \multirow{2}{*}{$r \cdot}$. & 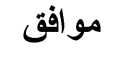 & \multirow[t]{2}{*}{$* * \ldots$} & \multirow{2}{*}{$10.0 \mathrm{HV}$} & \multirow{2}{*}{.711} & \multirow{2}{*}{$1 . v \leq r$} & 11 & rq & rr & 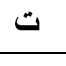 & \multirow{2}{*}{ يخلق تنافس محمود بين } & \multirow{2}{*}{ ry } \\
\hline & 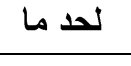 & & & & & $1 T . \varepsilon$ & $\varepsilon \vee .7$ & rq.. & $\%$ & & \\
\hline $18 \ldots$ & 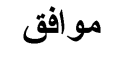 & ..ro & V.rEI &.$\vee \bullet \wedge$ & 1.V7^ & 17 & $r_{1}$ & ro & $ت$ & يستثمر طاقات الطلاب بطريقة & rv \\
\hline & 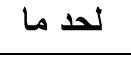 & & & & & 19.0 & rv.ı & $\varepsilon r \cdot V$ & $\%$ & جيدة. & \\
\hline $17 \ldots$ & 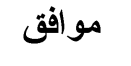 & $* * \ldots r$ & $|r| V \mid$. &..$V \cdot r$ & I.V^. & ir & $r \wedge$ & 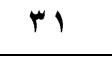 & $ت$ & يوفر قدرا من المتابعة لأداء & $\mu \wedge$ \\
\hline & 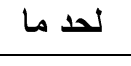 & & & . & & 10.9 & $\varepsilon 7 . r$ & rv.ı & $\%$ & المعلمين. & \\
\hline rr.. & 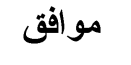 & $* * \ldots r$ & ir.rq. &.$v 01$ & $1.7 \wedge r$ & $1 \varepsilon$ & $r \wedge$ & $\varepsilon$. & $ت$ & يطور من أسلوب تفكير & $\mathrm{rq}$ \\
\hline & لعد ما & & & & & $1 v .1$ & $r \varepsilon .1$ & $\varepsilon \wedge . \wedge$ & $\%$ & الطلاب. & \\
\hline
\end{tabular}




\begin{tabular}{|c|c|c|c|c|c|c|c|c|c|c|c|}
\hline الرتبة & درجة المو افقة & الالالة & قيمة & الآمراف & المتوسط & موافق & موافق & غوافير & $ت$ & 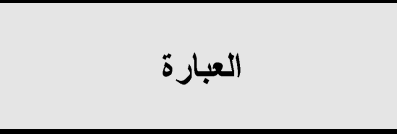 & الرقم \\
\hline \multirow[b]{2}{*}{$r \cdot . \cdot$} & \multirow[b]{2}{*}{ موافق } & \multirow{2}{*}{$* * \ldots \varepsilon$} & \multirow[b]{2}{*}{$11 . r 9 \%$} & \multirow[b]{2}{*}{. .217} & \multirow[b]{2}{*}{$1 . v \leq r$} & ir & ro & $r \varepsilon$ & $ت$ & \multirow{2}{*}{ يمكن المعلم من الكثف عن } & \multirow[b]{2}{*}{$\varepsilon$. } \\
\hline & & & & & & 10.9 & $\varepsilon Y . V$ & $\$ 1.0$ & $\%$ & & \\
\hline \multirow{2}{*}{$r \cdot . \cdot$} & \multirow{2}{*}{ موافت } & \multirow{2}{*}{$* * \ldots$} & \multirow{2}{*}{ 10.0rv } & \multirow{2}{*}{.710} & \multirow{2}{*}{$1 . v \leq r$} & 11 & $r q$ & rr & $ت$ & \multirow{2}{*}{ يجعل الطالب متعلما نشطا } & \multirow{2}{*}{ 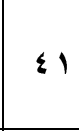 } \\
\hline & & & & & & Ir.z & $\varepsilon \vee .7$ & rq.. & $\%$ & & \\
\hline \multirow{2}{*}{19.} & \multirow{2}{*}{ موافق } & \multirow{2}{*}{$\cdots \varepsilon r$} & \multirow{2}{*}{ T.riv } & \multirow{2}{*}{.$\vee \vee \vee 1$} & \multirow{2}{*}{$1 . \vee \wedge$} & iv & r. & ro & $ت$ & \multirow{2}{*}{ المعلومات من مصادر متعددة للبحث عن } & \multirow{2}{*}{$\varepsilon r$} \\
\hline & & & & & & $r \cdot . V$ & r. & $\varepsilon r . V$ & $\%$ & & \\
\hline \multirow{2}{*}{ ir.. } & \multirow{2}{*}{ موافت } & \multirow[t]{2}{*}{$* * \ldots 1$} & \multirow{2}{*}{$q . r \leq \varepsilon$} & \multirow{2}{*}{. vrr } & \multirow{2}{*}{$1 . \wedge 1 \mathrm{~V}$} & 10 & rv & r. & $ت$ & \multirow{2}{*}{ فرير ما بين الطالب من فرودية. } & \multirow{2}{*}{$\varepsilon r$} \\
\hline & & & & & & $1 \wedge . r$ & $\varepsilon 0.1$ & T & $\%$ & & \\
\hline \multirow[b]{2}{*}{ भ.. } & \multirow[b]{2}{*}{ لموافق ما لح ما } & \multirow[b]{2}{*}{$\cdots 11$} & \multirow[b]{2}{*}{9.991} & & & 19 & $\varepsilon$. & $r r$ & $ت$ & يقيد حرية المعلم في اختيار & \\
\hline & & & &.$v \backslash \wedge$ & 1.901 & rr.r & $\varepsilon \wedge . \wedge$ & r^.. & $\%$ & وسيلة التقويم المناسبة & $\varepsilon \varepsilon$ \\
\hline r & موافق & va & W & $\forall v=$ & $r, a$ & $m \varepsilon$ & $r$ & 11 & $ت$ & يجب إلفاؤه لأنه لا يختلف عن & \\
\hline $1 .$. & ل لحد ما & $\cdots \sqrt{7}$ & $0.0 r$ & . vr & 1.170 & $\varepsilon 1.0$ & r.. & rr.. & $\%$ & طرق التقويم العادية. & 20 \\
\hline 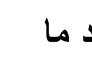 & موافق & & &..$\leqslant 7 V$ & I.^s. & & & & 1 & & \\
\hline
\end{tabular}




\section{التضح من نتائج الجدول (V) ما بلي:}

أنّ جميع فقرات المقياس قد حازت على درجة مو افق لحد ما من التقدير.

وقد جاءت بالمرتبة الأولى الفقرة رقم(؟) و التي تتص على: " يتطلب إعادة بناء

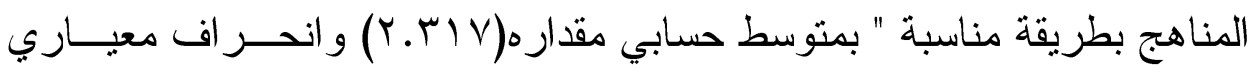
مقداره (V)V . • . .). وتتفق مع استجابة معلمي المرحلة المتوسطة، إذ يرى معلمي المرحلة الثانوية أن تبني مشروع التقويم الثامل بجميع عناصره و أدو اته ووسائله سيتطلب من وزارة التزبية و التعليم ضرورة إعادة النظر فــي المنـــاهج وأدوات التقويم المستخدمة بها، حتى تتو افق مع الطرح الجديد لمشروع التقويم الثامل.

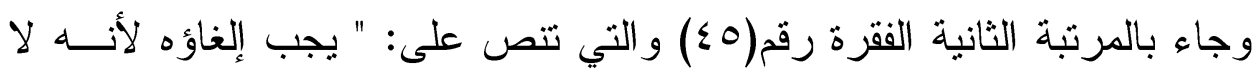

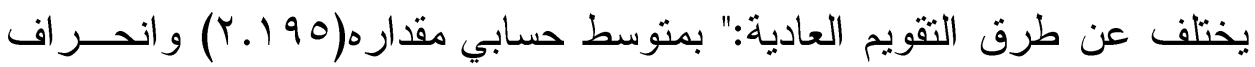

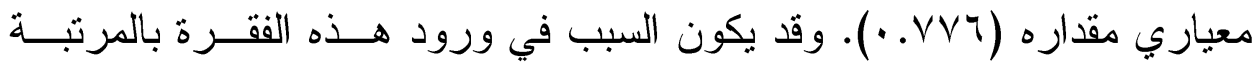
الثانية، كون التقويم الثامل لا ينفصل عن طرق التقويم العادية، بل يأخذ منهـــا ويضيف عليها، كما أن معلمي المرحلة الثانوية يعتمــدون علــى الاختبــار ات

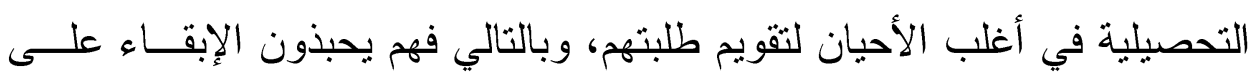
الثيء القديم، كونه أسهل ومباشر لتقويم الطلبة. وقد يعود السبب في ذلك الــى عدم معرفة المعلمين بالأدوات و الأساليب و الاجر اءات الخاصة بالتقويم الثــامل،

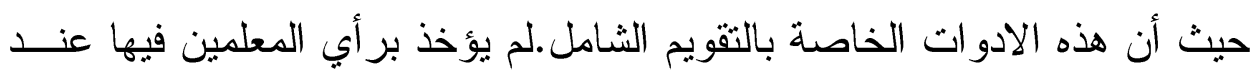
بنائها. فالاعتر اف بشخصية المعلم وجعله بشعر بمسؤولية تجاه تعلــيم طلابـــه و إثر اكه في عملية اتخاذ القرار ولو باستبانة توزع عليهم للتعرف على آرائهــ فيما تنوى الوزارة تطبيقه. 
- وللتحقق من الفرض الثاني للار اسة والأي ينص على

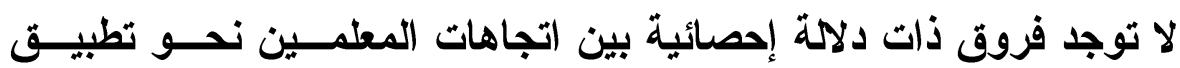
التقويم الثامل (الأبعاد، والارجة الكلية) تعزى إلى المؤهل العلمي، عدد سنوات الخبرة، والمرحلة التعليمية التي يعملون بها. أولًا: بالنسبة لاختبار دلالة الفروق إحصائًا في البعد الاول (الاتجاه نحسـو دور التقويم الثامل في الارتقاء بمستوى الطلاب) في ضوء متغيرات الدراســـة التصنيفية الثلاثة (المؤهل العلمي -الخبرة-المرحلة التعليمية) وفي ضــــوء

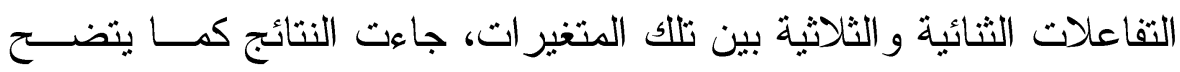
بالجدول التالي: - n

جدول (^) نتائج تحليل التباين الثلاثي (المؤهل *الخبرة**المرحلة التعليمية) بالنسبة الى الاتجاه نحو دور التقويم الشامل في الارتقاء بمستوى الطلاب

\begin{tabular}{|c|c|c|c|c|c|}
\hline الدالاة & قيمة ف & متوسطات & الحرية & المربعات & \\
\hline$\cdot . \leqslant \leq Y$ &. .119 & Ar.zI & r & $174.1 \mathrm{r}$ & المؤهل \\
\hline.$v R v$ & . . $\{r r$ & $\varepsilon r . \cdot V \uparrow$ & $r$ & IYQ.YYA & الخبرة \\
\hline .900 & $\ldots \leqslant V$ & $\varepsilon . V \Psi V$ & r & $9 . \leqslant \vee \leqslant$ & المرحلة التعليمية \\
\hline$. r \leq q$ & 1.009 & $1 \cdot V . \Lambda 1 r$ & $r$ & $r 10.7 r r$ & المؤ هل * الخبرة \\
\hline$. r \leqslant V$ &.$\wedge \wedge q$ & $9 . .0 V Y$ & 1 & $q . .0 V Y$ & المؤهل * المرحلة \\
\hline. .191 & 1.019 & $10 \leqslant . V 10$ & $\varepsilon$ & \イ.А५. & الخبرة * المرحلة \\
\hline- & - & - & صفز & $\cdots \cdots$ & الخبرة "المؤهل * التعلة \\
\hline
\end{tabular}


اتضح من نتائج الجدول (^): عدم وجود فروق ذات دلالة إحصائيًا بين استجابات أفر اد عينة الدراسة في الاتجاه نحو دور التقويم الثامل في الارثقـاء

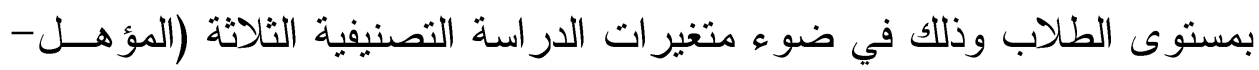

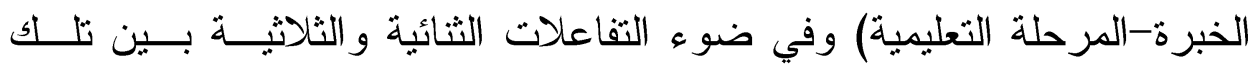
المتغيرات، وبذلك يقبل الباحث الفروض الصفرية السبعة السابق ذكرها ويرفض أن الفروض البديلة. وقد يعزى السبب في ذلك إلى أنّ جميع المعلمين - على الرغم من اختلاف مؤهلاتهم العلمية أو اختلاف المراحـل الدراســية التــي يقومـــون بالتّريس بها - بتلقون نفس برامج التّريب الخاصة بالتقويم الثامل، سواء كان هذا التدريب في الجامعات، أو من خلال ورش العمل وبرامج التـدريب التـي تعقدها وزارة التربية و التعليم في المملكة بشكل دوري، أو من خــلال النــدوات و اللقاءات التي تعقد بشكل دوري مع المعلمين سواء كانت هذه اللقاءات من قبــلـ

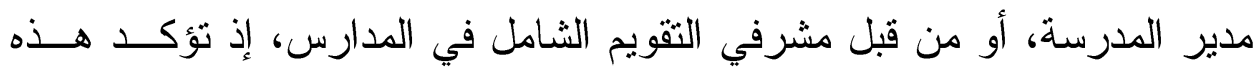
اللقاءات على ضرورة تبني مشروع التقويم الثامل من أجل الارتقاء بمسـتوى الطلاب. ثانيًا: بالنسبة لاختبار دلالة الفروق الإحصائية في البعد الثاني (الاتجاه نحو دور التقويم الشامل في تحسين العملية التعليمية) في ضوء متغيرات الدراســـة التصنيفية الثلاثة (المؤهل-الخبرة-المرحلة التعليمية) وفي ضوء التفاعلات الثنائية و الثلاثية بين تلك المتغير ات، جاءت النتائج كما بتضـــح بالجــدول التالي: 
جدول (9) نتائج تحليل التباين الثلاثي (المؤهل *الخبرة*المرحلة التعليمية) بالنسبة الى الاتجاه نحو دور التقويم الثامل في تحسين العملية التعليمية

\begin{tabular}{|c|c|c|c|c|c|}
\hline الدالاة & قيمة ف & متوسطات & الحرية & مجموع المربعات & \\
\hline$\because \vee \wedge \vee$ & . & १. . ० & r & $1 \mathrm{r.01V}$ & المؤهل \\
\hline 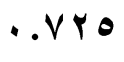 & $\cdot . \leqslant \varepsilon$. & I r.\&YY & $r$ & $r v . r \cdot \Lambda$ & الخبرة \\
\hline .9117 & $\ldots 1 \leq$ & . & r & .var & المرحلة التعليمية \\
\hline 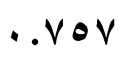 &.$r \vee q$ & V.^91 & r & 10.VAr & المؤهل *الخبرة \\
\hline 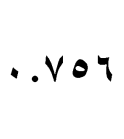 & $\ldots 9 V$ & $Y . V \leqslant V$ & 1 & $Y . V \leqslant V$ & المرحلة التعليمية \\
\hline T & $1 . \wedge r r$ & $01.01 \mathrm{r}$ & $\varepsilon$ & $Y .7 . .0$. & الخبرة" المرحلة \\
\hline - & - & - & صفز & $\cdots \cdots$ & الخبرة المرحة التعليمية \\
\hline
\end{tabular}

يتضح من نتائج الجدول (9). عدم وجود فروق ذات دالة إحصائيًا بين استجابات أفر اد عينة الدراسة في الاتجاه نحو دور التقويم الثامل فـي تحســين

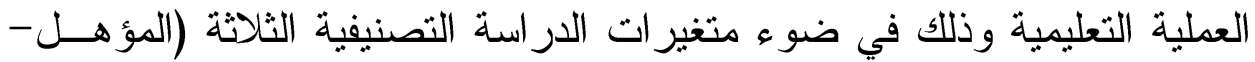

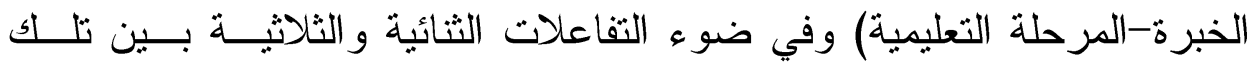
المتغيرات، وبذلك يقبل الباحث الفروض الصفرية السبعة السابق ذكرها ويرفض الفروض البديلة. ويمكن تفسير هذه النتيجة في ضوء أن المعلمين جميعًا باختلاف المؤهل وباختلاف المر احل التعليمية يرون أن تطبيق التقويم الثامل لهدور فـي تحسين العملية التعليمية. الجدول رقم (^). كما لم تظهــر فـروق دالــة بــين متوسطات درجات المعلمين وفقاً للمؤهل التعليمي (دبلوم-بكالوريوس-ماجستير) و المرحلة التعليمية (ابتدائي سمتوسط-ثانوي) على مقياس الاتجاه نحــو تطبيــق 
التقويم الثامل (الأبعاد و الدرجة الكلية) باستثناء بعد الاتجاه نحو دوره في تحسين عملية التقويم، فقد وجدت دلالة لتفاعل المؤهل مع المرحلة التعليمية فقط، معنى ذلك أن المعلمين ذوي المؤهل العالي وذوي المؤهل المتوسط يرفضون تطبيــق

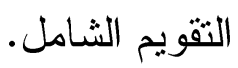

وقد يعزى السبب في ذلك إلى أنّ جميع المعلمين - على الــرغم مــن اختلاف مؤهلاتهم العلمية - يتلقون نفس بر امج التذريب الخاصة بالتقويم الشامل، سو اء كان هذا التدريب في الجامعات، أو من خلال ورش العمل وبر امج التدريب التي تعقدها وزارة التربية والتعليم في المملكة بشــل دوري، أو مــن خــلال الندوات و اللقاءات التي تعقد بشكل دوري مع المعلمين سواء كانت هذه اللقاءات من قبل مدير المدرسة، أو من قبل مشرفي التقويم الثامل في المدارس، إذ تؤكد

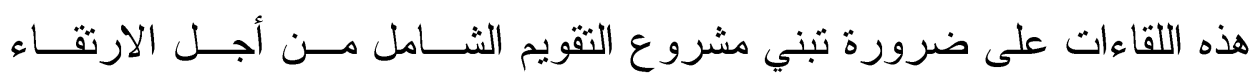
بمستوى الطلاب، الأمر الذي يسهم في تحسين العملية التعليمية ومن ثم تحســين عملية التقويم، وبالتالي الوثوق بعملية التقويم ونو اتج التعلم. وتتفق هذه النتيجة مع

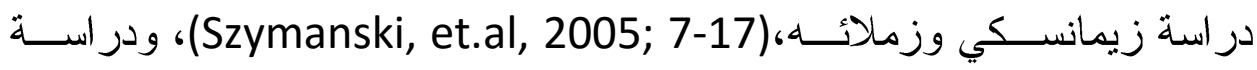
كريستوفر (Christopher, 2004: 392-4118). ثالثًا: بالنسبة لاختبار دلالة الفروق إحصائيًا في البعد الثالث (الاتجاه نحــو دور التقويم الثـامل في تحسين عملية التقويم) في ضـــوء متغيــر ات الدراســـة التصنيفية الثلاثة (المؤهل -الخبرة-المرحلة التعليمية) وفي ضوء التفاعلات الثنائية و الثناثية بين تلك المتغير ات، جاءت النتائج كما يتضـــح بالجـدول التالي: 
جدول ( • 1) نتائج تحليل التباين الثلاثي (المؤهل *الخبرة*"المرحلة التعليمية) بالنسبة الى الاتجاه نحو دور التقويم الثامل في تحسين التقويم الثامل

\begin{tabular}{|c|c|c|c|c|c|}
\hline مستوى الدلامة & قيمة ف & متوسطات & الحرية & المربعات & ) \\
\hline 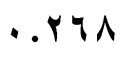 & I.ru & $\varepsilon V . \wedge \bullet$ & r & $90 . v \cdot 1$ & المؤهل \\
\hline. $.7 V V$ & .0 .9 & Mr.Mr & $\mu$ & $00 \ldots$ & الخبرة \\
\hline .999 & $\cdots \leqslant V$ & Y.701 & r & $0 . r .1$ & المرحلة التعليمية \\
\hline$\cdot . \wedge \leqslant \wedge$ &. .174 & 0.979 & r & $11.94 \mathrm{~V}$ & المؤهل *الخبرة \\
\hline מד & . YYY & $\Lambda . r \cdot \Lambda$ & 1 & $\Lambda . r \cdot \Lambda$ & المرحلة التعليمية \\
\hline. $.74 r$ & $\cdot .7 \cdot r$ & 91.797 & $\varepsilon$ & ヘч.VA & الخبرة* المرحلة \\
\hline- & - & - & صفر & $\cdots \cdots$ & الخبرة المؤهلة التعليمية \\
\hline
\end{tabular}

يتضح من نتائج الجدول ( • (1): عدم وجود فروق ذات دلالة إحصــائيًا بين استجابات أفر اد عينة الدر اسة في الاتجاه نحو دور التقويم الثامل في تحسين

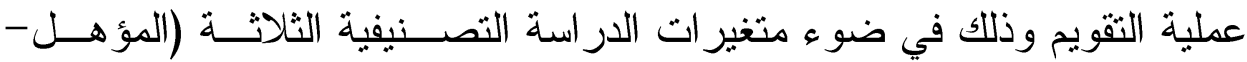

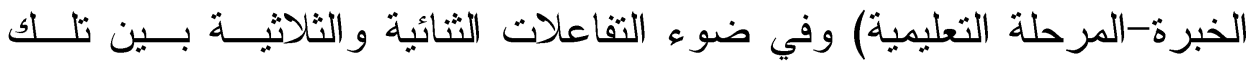
المتغير ات، وبذلك يقبل الباحث الفروض الصفرية السبعة السابق ذكرها ويرفض الفروض البديلة. ويمكن تفسير هذه النتيجة في ضوء أن المعلمين جميعًا اتفقــوا على توظيف التقويم الثـامل بطريقة فعالة استثمار الطاقات التلاميــذـ ومـــــاهبهم وتفاديًا لمعوقاته. وتتفق هذه النتيجة مع در اسة زيمانسكي ودر اســة كريســتوفر السابق ذكرهما والتي وجهتا الأنظار الى ضرورة تدريب المعلهـين التـدريب الكافي على تطبيق التقويم الثامل وكذلك توفير الامكانــات اللازمـــة فالمؤهـلـل 


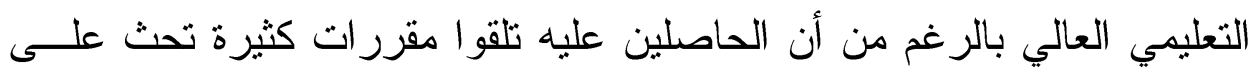

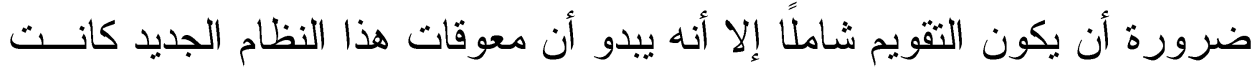
أقوى أثرًا على المعلمين. وقد جاءت نتائج هذه الدر اسة متو افقة مع نتائج در اسة

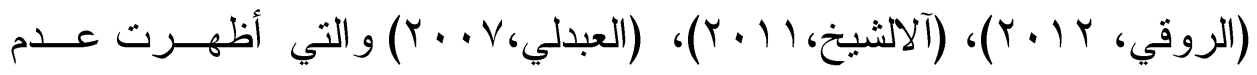
وجود فروق ذات دلالة إحصائية بين عينة الدراسة تجاه التقويم الثامل تعـزى إلى متغير المؤهل العلمي. رابعًا: بالنسبة لاختبار دلالة الفروق إحصائيًا في الارجة الكلية في الاتجاه نحــو

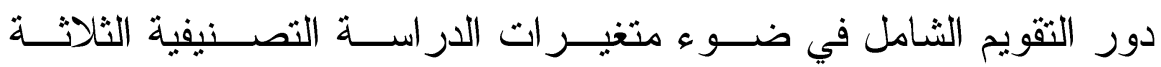
(المؤهل -الخبرة-المرحلة التعليمية) وفي ضوء التفاعلات الثنائية و الثلاثية بين تلك المتغيرات، جاءت النتائج كما يتضح بالجدول التالي: جدول (11) نتائج تحليل التباين الثلاثي (المؤهل *الخبرة*"المرحلة التعليمية) بالنسبة الى الارجة الكلية في الاتجاه نحو دور التقويم الثامل

\begin{tabular}{|c|c|c|c|c|c|}
\hline مستوى الدلاكة & قيمة ف & متوسطات & الحرية & المربعات & \\
\hline . YYA & $\cdot . \leqslant \leq 7$ & 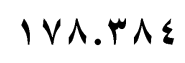 & r & 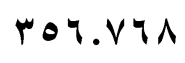 & المؤهل \\
\hline $.7 V V$ & .ror & 1. 1.rvo & $r$ & r.s. & الخبرة \\
\hline .949 & $\ldots r l$ & 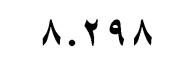 & r & 17.097 & المرحلة التعليمية \\
\hline$. \wedge \leq \wedge$ & . .0rt & $r l \cdot r \Delta q q$ & r & $\varepsilon r . . V I V$ & المؤهل *الخبرة \\
\hline צ &. $.2 q r$ & 198.1 .4 & 1 & $19 V .1 \cdot r$ & المرحلة التعليمية \\
\hline צד ד . & 1.19. & $\varepsilon \vee 7 . \varepsilon \wedge q$ & $\varepsilon$ & $\begin{array}{c}19.0 .90 \\
0\end{array}$ & الخبرة * المرحلة \\
\hline- & - & - & صفر & $\cdots \cdots$ & الخبرة "المؤهل * التعليمية \\
\hline
\end{tabular}


يتضح من نتائج الجدول (11). عدم وجود فروق ذات دلالة إحصــائيًا

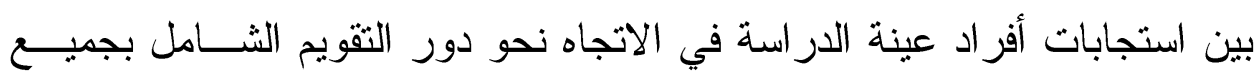

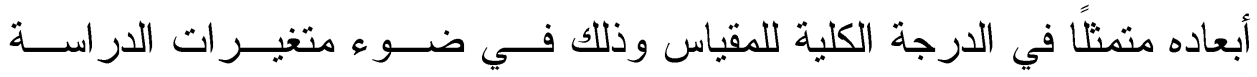

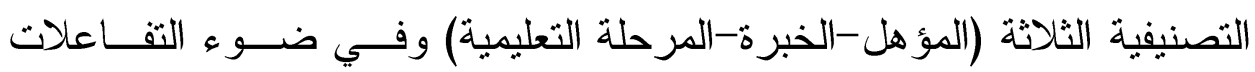
الثنائية و الثلاثية بين تلك المتغير ات، وبذلك يقبل الباحــث الفـروض الصــفرية

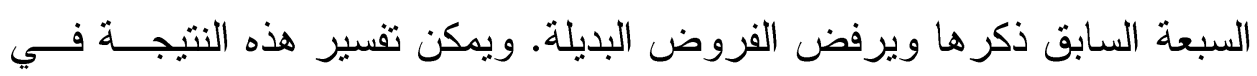

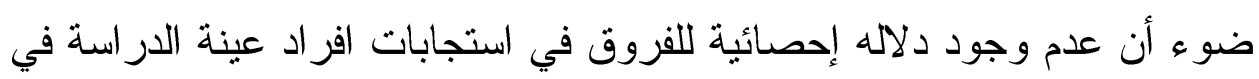
أي من الاتجاه نحو التقويم الثامل للارتقاء بمستوى الطلاب أو تحسين العمليــة فئة

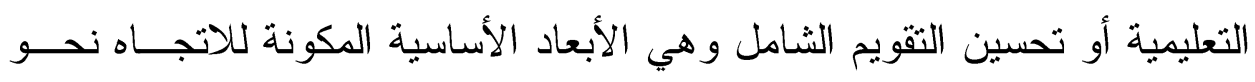

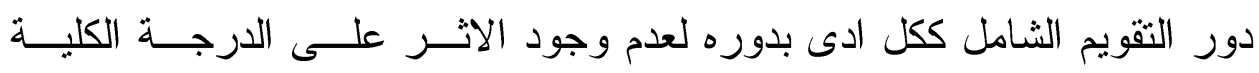
للمقياس. وقد يكون السبب من عدم وجود الفروق الدالة إحصائيًا كــون جميـع

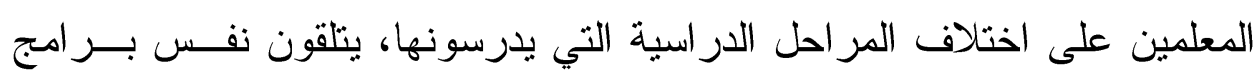

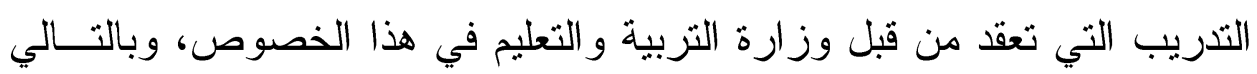
تتولد لديهم اهتمامات و اتجاهات بشأن موضوع التقويم الثامل و الذي يعدّ بمثابة

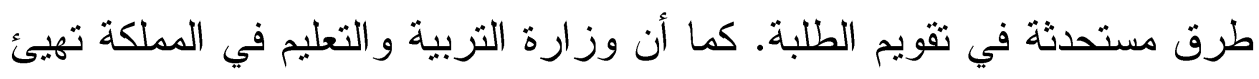
الفرصة لجميع المعلمين - بالرغم من اختلاف المر احل التي يدرسونها - إلـى

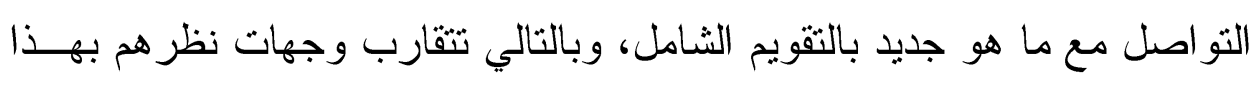

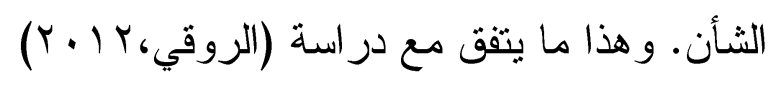
وقد يعود السبب في عدم وجود فروق دالة إحصائيًا في جميع فــروض إنسا أبعاد الاتجاه نحو التقويم الثامل ودرجته الكلية برجع إلى عدم معرفة المعلمـين

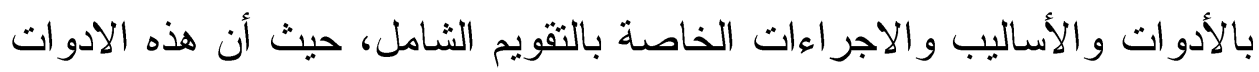


الخاصة بالتقويم الشامل.لم يؤخذ برأي المعلمين فيها عند بنائها سواء كان هؤلاء المعلمين مبتدئين أو خبر اء من اصحاب الدراسات العليا او المتوســطة بــالتعليم الابتدائي أو المتوسط او الثانوي. فالاعتر اف بشخصية المعلــم وجعلــهـه بشــعر بمسؤولية تجاه تعليم طلابه و إثر اكه في عملية اتخاذ القرار ولو باستبانة تـوزع عليهم للتعرف على آر ائهم فيما تنوى الوزارة تطبيقه تجعله يــتحمس فــي اداء العمل و انجاحه لأنه أسهم في إعداده. وكذلك فإنّ أي جهد آخر سيبذل من قبــلـ المعلم نحو تتفيذ التقويم الثامل، وتبني سياسة تقويم جديدة لتقويم الطلبة. و التحول

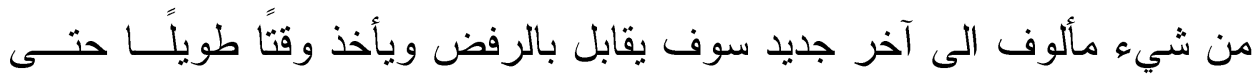
يعتاد عليه الأفر اد وخاصة عند عدم الاتجاه الايجابي من قبل القائمين على تتفيذه.

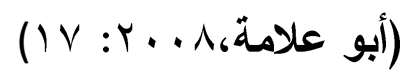




\section{توصيات الدراسة:}

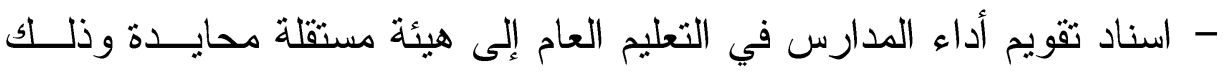

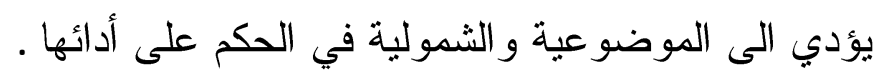

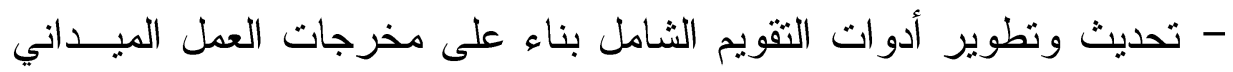
و التغيير المستمر في المقررات. - تخصيص مقرر مستقل بمسمى (التقويم الثامل) يدرس للطالب في كليـات التيات التربية في برامج إعداد المعلم.

- عقد دورات تدريبية مكثقة للمعلمين لتدريبهم على تجويد التقويم الثامل - تدريب الطالب المعلم في كليات التربية على مهــار ات اســتخدام الحقائَبـ

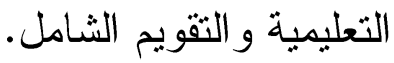
- إثر الك المعلمين في صنع القرارات التربوية . بحوث مقترحة: - دراسة منطلبات تطبيق التقويم الخارجي للمدرسة في مدارس التعليم العـام في المملكة. - دور التقويم الثامل في تحقيق الجودة الثاملة لاى منسوبي وزارة التعليم. - فعالية التدريب على تطبيق التقويم الثامل في تعديل اتجاهات المعلمين. - إجر اء دراسة بحثية لبناء معايير ومؤشر ات لمكونات نظام الثقويم الثامل. 


\section{المراجـ}

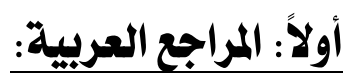

- أبو علامة، عبداله علي( 1 . ㄷ)التقويم الثامل في وزارة التربية والتعليم :ماذا

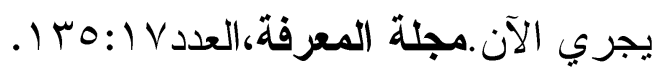

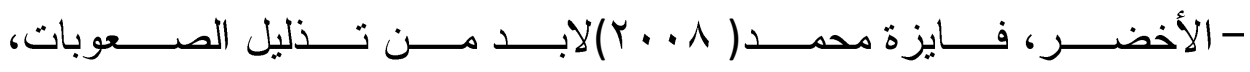

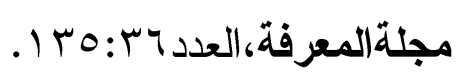

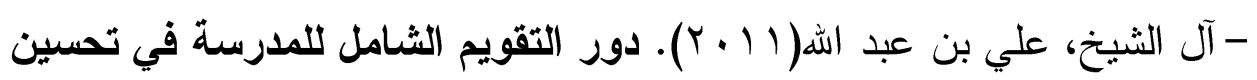
أداء مديري المدارس الابتدائية :دراسة ميدانية بمنطقة عسير التعليميسة . رسالة ماجستير غير منشورة ،كلية التربية، جامعة الملك خالد.

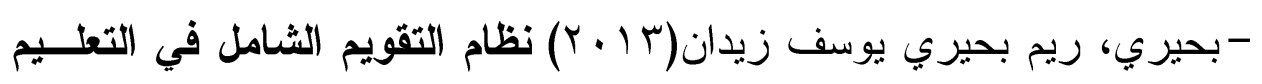

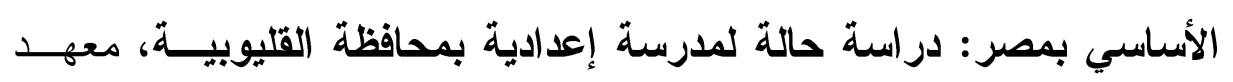
الدر اسات و البحوث التربوية- قسم أصول التربية ـ جامعة القاهرة.

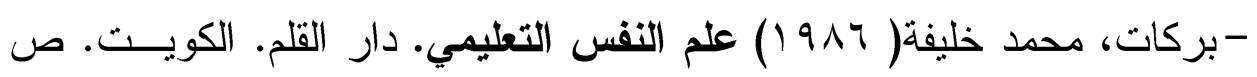
$.|V Y-| V \mid$

- بن عبد الرحمن، حمد أيمن محمد (ع ( ب ب). اتجاهات المعلمين نحو التقـويم

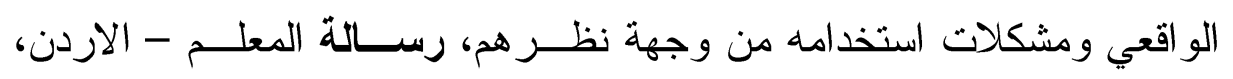

$$
\text { rO-r } 6(r) 016 r \cdot 1 \varepsilon
$$

- البيلاوي،حسنحسين(797 997 ) إدارة الجودة الثاملة في التعليم العالي بمصـر . مؤتمر التعليم العالي في مصر وتحديات القرن الحادي والعثـــين .جامعــة المنوفية، بالتعاون مع مركز إعداد القادة، الجهاز المركزي للتنظــيم و الإدارة، القاهرة، جمهورية مصر العربية. 
- جابر، عبد الحميد جابر( §99 1) علم النفس التربــوي، ط ب، دار النهضـــة

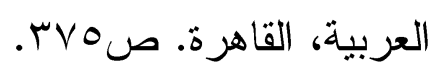

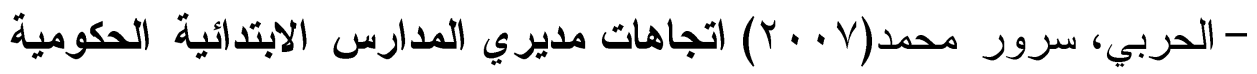
ومعلميها بالمنطقة الثرقية من المملكة العربية السعودية نحو التقويم الثامل للمدرسة، رسالة ماجستير غير منشورة. كلية التربية، الجامعة الوطنية، تعز،

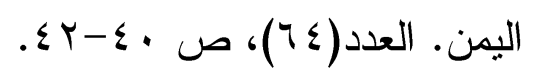

- الدوسري، صالح محمد عبد الله( + . ب). فعالية التقويم الثامل من وجهــة

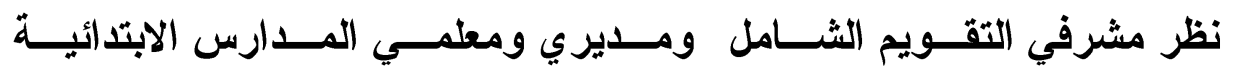
المقومــة.رسالة دكتور اه غير منشورة.كلية التربية .جامعـــة أم القــرى.مكــة

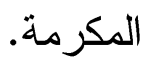

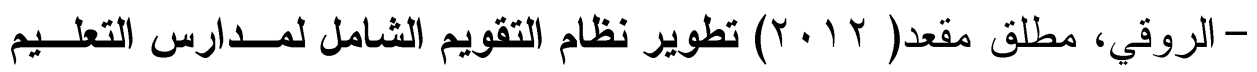
العام في ضوء إدارة الجودة الشاملة، رسالة دكتور اه غير منشـــوره، كليــة العلوم الاجتماعية - إدارة وتخطيط تربوب، جامعة الإمام محمد بـن ســود الإسلامية. -ز هران، حامد عبد السلام( \&99 (1) علم النفس الاجتماعي. طس، عالم الكتب، مصر. صמדזו.

- السيد أحمد، شكري(99V ( 99 ) در اسة انتقاديه لبحوث در اسات التقـــويم الثــــامل

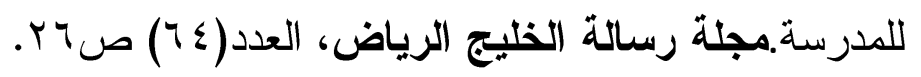

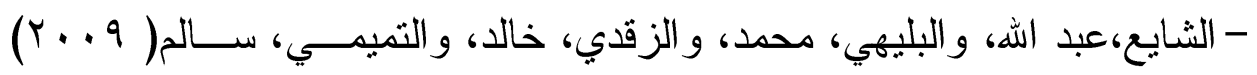
دور مشروع التقويم الثامل للمدرسة في العملية التربوية التعليمية بمدارس 
البنين في منطقة حائل التعليمية :دراسة مقدمة إلى جـائزة مكتــب التربيــة

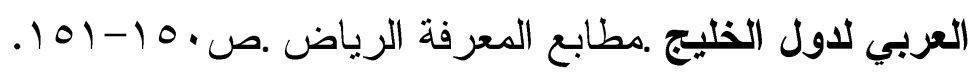
- الثر اري ،فايز ظاهر (9 . . ب). عو ائق التقويم الثامل للمدرسة.مجلة المعرفة،

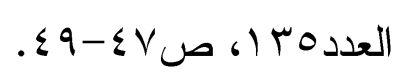

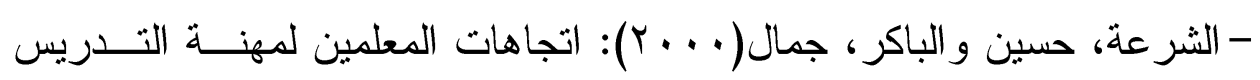
بدولة قطر ومدى تأثرها ببعض العوامل الديمغر افية، المجلة التربوية، المجلد:

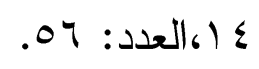

- شلبي، أمينة إبراهيم، 1991 ا اتجاهات المعلمين نحو إلغاء التقــويم البنـائي

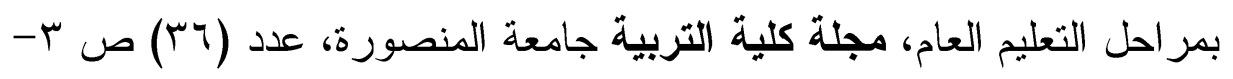
..

- الثنقيطي، سعاد حسن(V . . r). مقال عن التقويم الثامل ولد قوياً وأصابه من

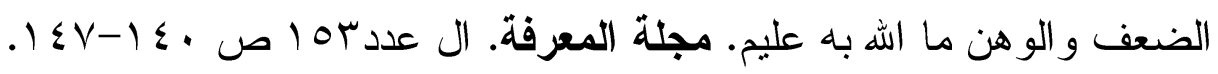

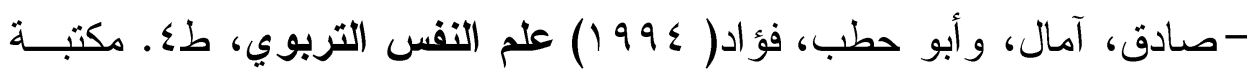

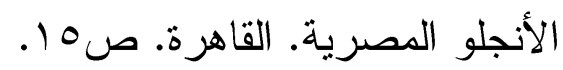

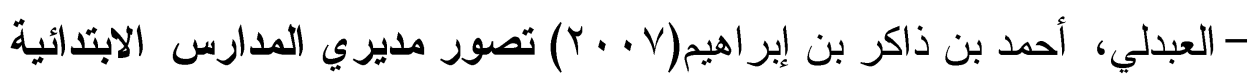
في محافظة القتفذة لتطبيق خطة التقويم الثامل والصعوبات التي تواجههم، رسالة ماجستير غير منشورة. كلبة التربية، جامعة عدن. الجمهورية اليمنية. - العتيبي، صالح شمرو خ( V . . Y). الكفايات اللازمة لمشرفي الثقويم الثــامل بالمدرسة بمنطقة الرياض التعليمية .رسالة ماجستير غيــر منشــورة .كلبـــة التربية .جامعة الملك سعود، الرياض. 
- عرفان، خالد محمود(0 . . ب)(التقويم التراكمي الثامل ومعوقات استخدامه في مدارسنا. عالم الكتب، القاهرة. ص ب Vq-V.

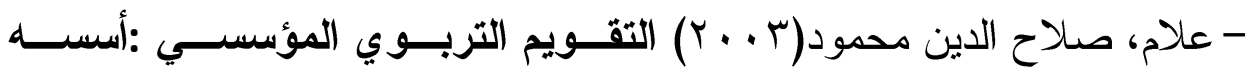
ومنهجياته وتطبيقاته فــي تقــويم المـــارس. دار الفكـر العربــي للنشــر

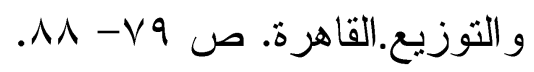

- عيسان، صالحة و الثيدي، فائزة (1 1 • ب) درجة تطبيق الجودة الثــاملة فـي مدارس التعليم ما بعد الأساسي من وجهة نظر المشرفين التربويين و المعلمين الأوائل في سلطنة عمان، مجلة الاراسات النفسية والتربوية جامعة السلطان

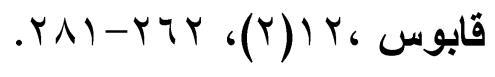

- مرسى، محمد منير(990 (190). الإدارة المدرسية الحديثة. عالم الكتب. القاهرة.

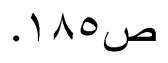

- مندوه محمود، وليد أبو معطي(Y) . . . . . اتجاهات معلمي المرحلــة الابتدائيــة نحو تطبيق التقويم الشامل، بحث منشور في كلية التربية، جامعــة أســـوط

$$
\text { . Tr-r מ n n. }
$$

-وزارة التربية والتعليم، المملكة العربية السعودية(0 . ب). الاليل العام لتقويم

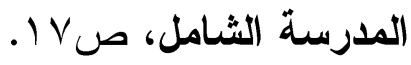

\section{ثانياً: المراجع الأجنيبة:}

- Anthony T Milanowski, Herbert G Heneman. (2001) Assessment of teacher reactions to a standards-based teacher evaluation system: A pilot study. Journal of Personnel Evaluation in Education 15 (3), 193-212. 
- Christopher, H. (2004) Using teacher portfolios to enrich the methods course experiences of prospective mathematics teachers, School Science and Mathematics. 104(8): 392-418.

- George, G. (2001) Who will teach our children? Rural National Board Certified teacher's Experiences, Information Analysis; Speeches / meeting papers.

- LuraGoe, Lynn Holdheide, Tricia Miller. (2011) Practical Guide to Designing Comprehensive Teacher Evaluation Systems: A Tool to Assist in the Development of Teacher Evaluation Systems. National Comprehensive Center for Teacher Quality.

- Marilyn, H. (2005) Are you ready to go digital? The Pros and Cons of electronic portfolio development, Journal articles; Opinion papers. Library Media Connection. 23(7):66.

- Marlow, E. (2000) Appraising progress in Middle school reading instruction, Journal citation in USA, New York.

- Richard Halverson, Carolyn Kelley, Steven Kimball. (2004) Educational administration, policy, and reform: Research and measurement, 153-188.

- Robert, B., Allen, B., and James, V. 1998. Preparing educational leaders with portfolio assessment, an alternative comprehensive Examination. Journal of Instructional Psychology. 25(2): 94 - 99. 
- Szymanski, S., Theresa, C.; Dennis, W., and Craig, S. (2005). Elementary teacher Candidate's construction of criteria for selecting, Social Studies Research. 39(1): 7-17.

- Wiggins, G. 1990. The Case for Authentic Assessment, ERIC document reproduction service Ed 328611.

- Winefield, A., Tiggemann, M., and Goldney, R. (1991) A longitudinal study of the psychological effects on unemployment and unsatisfactory employment on young adults. Journal of Applied Psychology. 76(24).

Yehudit, J. and Orit, H. (2005) Case based long - term professional development of science teachers. International Journal of Science Education. 27(12): 1413- 1446. 